\title{
Emerging roles of small and long non-coding RNAs in Cardiac Disease
}

Citation for published version (APA):

Beijnsberger, S. (2019). Emerging roles of small and long non-coding RNAs in Cardiac Disease. [Doctoral Thesis, Maastricht University]. ProefschriftMaken Maastricht. https://doi.org/10.26481/dis.20190522sh

Document status and date:

Published: 01/01/2019

DOI:

10.26481/dis.20190522sh

Document Version:

Publisher's PDF, also known as Version of record

\section{Please check the document version of this publication:}

- A submitted manuscript is the version of the article upon submission and before peer-review. There can be important differences between the submitted version and the official published version of record.

People interested in the research are advised to contact the author for the final version of the publication, or visit the DOI to the publisher's website.

- The final author version and the galley proof are versions of the publication after peer review.

- The final published version features the final layout of the paper including the volume, issue and page numbers.

Link to publication

\footnotetext{
General rights rights.

- You may freely distribute the URL identifying the publication in the public portal. please follow below link for the End User Agreement:

www.umlib.nl/taverne-license

Take down policy

If you believe that this document breaches copyright please contact us at:

repository@maastrichtuniversity.nl

providing details and we will investigate your claim.
}

Copyright and moral rights for the publications made accessible in the public portal are retained by the authors and/or other copyright owners and it is a condition of accessing publications that users recognise and abide by the legal requirements associated with these

- Users may download and print one copy of any publication from the public portal for the purpose of private study or research.

- You may not further distribute the material or use it for any profit-making activity or commercial gain

If the publication is distributed under the terms of Article $25 \mathrm{fa}$ of the Dutch Copyright Act, indicated by the "Taverne" license above, 


\section{Emerging roles of small and long non-coding RNAs in Cardiac Disease}

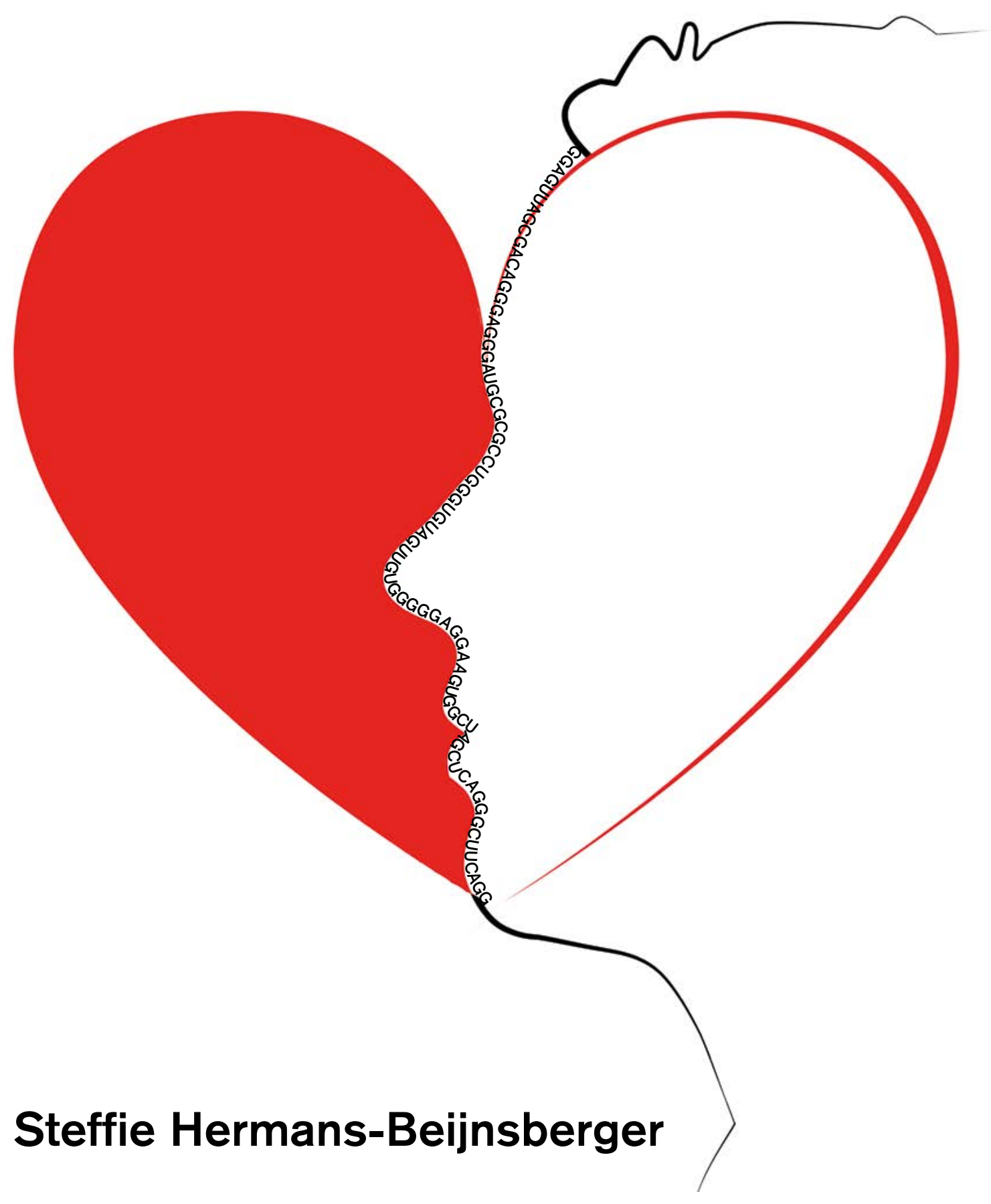


ISBN: 9789082980189

Cover design by: Auke Lansink

Printed by: ProefschriftMaken | www.proefschriftmaken.nl 


\title{
Emerging roles of small and
}

\section{long non-coding RNAs in Cardiac Disease}

\author{
PROEFSCHRIFT \\ Ter verkrijging van de graad doctor aan de Universiteit Maastricht, \\ op gezag van de Rector Magnificus, Prof. Dr. Rianne M. Letschert \\ volgens het besluit van het College van Decanen, \\ in het openbaar te verdedigen op \\ woensdag 22 mei 2019 om 16:00 uur.
}

door

Steffie Hermans-Beijnsberger

Geboren op 8 januari 1990 te Weert 


\section{Promoter}

Prof. Dr. Blanche Schroen

\section{Co-Promoter}

Dr. Marc van Bilsen

\section{Beoordelingscommissie}

Prof. Dr. L.J. Schurgers (voorzitter)

Prof. Dr. R.A. de Boer (Universitair Medisch Centrum Groningen)

Dr. V.P.M. van Empel

Prof. Dr. H.L. Roderick (Katholieke Universiteit Leuven)

Financial support by the Dutch Heart Foundation for the publication of this thesis is gratefully acknowledged. 
Just when I think I have learned the way to live,

life changes

Hugh Prather 

Contents

Chapter $1 \quad$ General introduction 9

Chapter $2 \quad$ Long non-coding RNAs in the failing heart and 17

vasculature

Chapter $3 \quad$ Long non-coding RNA Malat1 Is dispensable during pressure

overload-induced cardiac remodeling and failure in mice.

Chapter 4 Absence of long non-coding RNA Neat1 protects from

Pressure overload-induced cardiac remodelling and failure.

Chapter 5 The tRNA-like molecule, mascRNA, affects cardiomyocyte

cell cycle progression and viral replication.

Chapter 6 MicroRNA-200c-3p induces cardiomyocyte hypertrophy

and cardiac dysfunction, and is involved in titin signaling.

Chapter $7 \quad$ General discussion

Addendum Summary

Samenvatting

Valorization

Dankwoord

About the author 



\section{Chapter 1}

General introduction 



\section{Heart Failure}

Heart failure (HF) is a major public health issue, affecting at least 26 million people worldwide ${ }^{1}$. Its prevalence will increase in the upcoming years due to an ageing population, resulting in tremendous costs for society ${ }^{1}$. Heart failure is defined by the inability of the heart to pump sufficient amount of blood to the rest of the body, and can be separated in two classes: heart failure with reduced ejection fraction (HFrEF) and heart failure with preserved ejection fraction (HFpEF). The condition of the heart is often measured by echocardiographic imaging, in which ejection fraction (the percentage of blood pumped out of the heart per contraction) is calculated. HFrEF patients have a dilated left ventricle with systolic dysfunction evidenced by impaired fractional shortening ${ }^{2}$. Contrary, HFpEF patients present often with diastolic dysfuction secondary to impaired relaxation or increased passive stiffness of the myocardial wall ${ }^{3}$. Hypertensive heart disease, valvular disease and the metabolic syndrome are the most important risk factor for the development of HFpEF, wherease coronary artery disease, ischemic heart disease and dilated cardiomyopathy are the leading cause for HFrEF ${ }^{4,5}$. Currently, all HF patients (also HFpEF) are treated with a combination of medications including Angiotensin-converting enzyme inhibitors, beta blockers and diuretics ${ }^{6}$, because no alternatives exist. Despite effective therapies, morbidity and mortality of HF patients are still high, with a poor quality of life ${ }^{7}$. HF risk factors can lead to the development of cardiac hypertrophy, cardiac inflammation, cardiac fibrosis, and metabolic disease-induced $\mathrm{HF}^{8,9}$.

Cardiac hypertrophy is an essential response of the heart to stress and injury. It develops under an increased workload, which causes thickening of the muscle tissue. As a first response, this is a harmless and necessary consequence to cope with the increased demand of the body, however, when prolonged, it can lead to heart failure. On a cellular level, cardiac hypertrophy is characterized by an increase in cardiomyocyte cell size, being either physiological or pathological ${ }^{10}$. In addition to an increased cardiomyocyte volume, reexpression of the fetal gene program and increased protein synthesis are hallmarks of pathological cardiac hypertrophy ${ }^{11}$. Cardiomyocyte hypertrophy can be triggered by biomechanical (stretch-sensitive) and neuro-humoral factors, such as pressure-overload ${ }^{12}$ and angiotensin- $\mathrm{II}^{13}$, respectively.

Inflammation is considered to play a role in many diseases, including CVD ${ }^{14}$. Cardiac inflammation can be present in hypertensive patients, ischemic heart disease and atherosclerosis in which immune cell infiltrated the heart ${ }^{15,16}$. Cardiac inflammation caused by autoimmune disease, a cardiotoxic agent or a viral infection ${ }^{17}$ is called myocarditis. Myocarditis is a challenging disease because of its diversity in clinical presentations and the variety in etiologies which makes it difficult to treat ${ }^{18}$. The most common cause of myocarditis is a viral infection (viral myocarditis, VM). Enteroviruses, adenoviruses but also herpes virus 6 , in the heart can develop into myocarditis ${ }^{19}$. At the cellular level, VM can be divided into 3 phases: the acute stage defined by direct injury of cardiomyocytes and innate immune cell infiltration; the subacute phase where the adaptive immune cells infiltrate the heart tissue and clean up the infected cardiomyocytes; and the chronic phase in which an autoimmune response and low-grade inflammation come into play ${ }^{20}$. To study the pathophysiology of VM, the enterovirus Coxsackievirus B3 is the most widely used ${ }^{20}$, and large efforts have been made to find new possible therapies ${ }^{18}$. 


\section{Non-coding RNA}

To find potential new therapeutics that can influence the development of hypertrophy and/or failure, the underlying pathophysiological mechanisms and associated inter- and intracellular signaling pathways need to be understood. Increased understanding can help us to find new molecules to interfere with specific parts of these pathways. Noncoding RNAs (ncRNAs) are increasingly recognized as integral parts of cellular signaling pathways and are considered attractive therapeutic candidates. NcRNAs can differ in length, from small and less than 200 nucleotides, for example microRNAs (miRs), to large ncRNAs with over 200 nucleotides named long ncRNAs (IncRNAs).

MiRNAs are transcribed by RNA polymerase II or III into pri-miR ${ }^{21,22}$. Some under control of transcription factors, others are transcribed together with their adjacent mRNAs. Once transcribed, the pri-miRs get cleaved by the Drosha complex into pre-miRs, essential for miR processing. In the nucleus, several post-transcriptional processes can edit the priand/or pre-miR including adenosine to inosine-editing ${ }^{23}$, heterogeneous nuclear ribonucleoprotein specific binding ${ }^{24}$, growth factors that influence activity of the Drosha complex ${ }^{25}$. These post-transcriptional processes could direct the miR to different target mRNAs, or change miR expression levels. Subsequently, pre-miRs get exported out of the nucleus by Exportin-5. Finally, miRs are loaded into the RNA-induced silencing or RISC complex in which Dicer, TRBP and Ago2 are joined and form the miR-mediated cleavage or blockage of mRNAs ${ }^{26}$. MiRs exert their effects by regulating mRNA levels in the cytoplasm and thereby can influence almost every signaling pathway in the cell. In cardiac cells, specific miRs have been proven to indeed regulate very distinct and important pathways. Hence, experimental manipulation of these miRs has led to an improved or worsening of the HF phenotype ${ }^{27}$.

On the other hand, IncRNAs are relatively new in the field of cardiology, and researchers have just started to unravel their regulatory functions in the heart ${ }^{28,29}$. LncRNAs are over 200 nucleotides in length, lack an open reading frame and are poly-adenylated. The can regulate gene expression at the transcriptional level, as well as, post-transcriptionally. Recently, we reviewed the cardiac functions of IncRNAs extensively ${ }^{30}$.

MiRNAs as well as IncRNAs have great therapeutic potential, as evidenced by several studies showing that regulating ncRNAs levels can improve cardiac function ${ }^{31-33}$. The major implications lie in preventing the development of heart failure, by interfering with cardiac hypertrophy, fibrosis or inflammation. However, therapeutic delivery, especially into the heart remains a major challenge ${ }^{34-36}$.

\section{Outline of this thesis}

The general aim of this thesis is to unravel the role of candidate non-coding RNAs in the development of cardiac hypertrophy and failure. Especially, experimental manipulation of candidate ncRNAs in vitro and in vivo has been applied to assess their biological function and their potential to slow down the development of hypertrophy and/or progression into cardiac failure. In this thesis the focus will be on IncRNAs initially. Chapter 2 provides an extensive review of the literature on the role of IncRNAs in cardiovascular disease. 
Specifically, IncRNAs involved in cardiac hypertrophy, fibrosis, inflammation, vascular disease and ageing are described, as well as their therapeutic potential. In Chapter 3 the role of Malat1 in pressure-overload induced heart failure was investigated, and we found no critical role for the IncRNA Malat1 in pressure overload-induced heart failure in mice. This chapter is followed by a chapter about its genomically neighboring transcript, Neat1. Neat1 turns out to play a crucial role in cardiac stress and cardiac hypertrophy. Knocking-out Neat1 completely blunts the development of pressure-overload induced cardiac failure, as outlined in Chapter 4. Next, a small tRNA-like molecule deriving from the Malat1 locus, mascRNA, and its role in viral myocarditis was studied in Chapter 5. In this chapter it is shown that mascRNA is able to inhibit CVB3 viral replication in vitro and in vivo. Finally, in Chapter 6 focus on the microRNA-200c-3p. This particular miR was identified before in a cellular screen for HF-associated miRs that are able to influence cardiomyocyte growth ${ }^{37}$. We explored its role in cardiomyocyte hypertrophy and found that its manipulation affects titin signaling, in vitro and in vivo.

The thesis is concluded with a general discussion (Chapter 7 ) in which the main findings are discussed in a more integrative manner. 


\section{References}

1. Savarese, G. \& Lund, L. H. Epidemiology Global Public Health Burden of Heart Failure. Card Fail Rev 3, 711 (2017).

2. Mosterd, A. et al. Prevalence of heart failure and left ventricular dysfunction in the general population; The Rotterdam Study. Eur Hear. J 20, 447-455 (1999).

3. Zile, M. R. et al. Heart Failure Myocardial Stiffness in Patients With Heart Failure and a Preserved Ejection Fraction Contributions of Collagen and Titin. 1247-1259 (2015). doi:10.1161/CIRCULATIONAHA.114.013215

4. Abebe, T. B., Gebreyohannes, E. A., Tefera, Y. G. \& Abegaz, T. M. Patients with HFpEF and HFrEF have different clinical characteristics but similar prognosis: a retrospective cohort study. BMC Cardiovasc. Disord. 16, 232 (2016).

5. Yusuf, S. et al. Effects of candesartan in patients with chronic heart failure and preserved left-ventricular ejection fraction : the CHARM- Preserved Trial. Lancet 362, 777-781 (2003).

6. Berliner, D. \& Bauersachs, J. Current drug therapy in chronic heart failure - The new guidelines of the European Society of Cardiology (ESC). Korean Circ. J. 47, 543-554 (2017).

7. Hobbs, F. et al. Impact of heart failure and left ventricular systolic dysfunction on quality of life A crosssectional study comparing common chronic cardiac and medical disorders and a representative adult population. Eur Hear. J 23, 1867-1876 (2002).

8. Rame, J. E. \& Dries, D. L. Heart Failure and Cardiac Hypertrophy. Curr Treat Options Cardiovasc Med 9, 289-301 (2007).

9. Suthahar, N., Meijers, W. C., Silljé, H. H. W. \& Boer, R. A. De. From Inflammation to Fibrosis - Molecular and Cellular Mechanisms of Myocardial Tissue Remodelling and Perspectives on Differential Treatment Opportunities. Curr Hear. Fail Rep 14, 235-250 (2017).

10. Shimizu, I. \& Minamino, T. Physiological and pathological cardiac hypertrophy. J. Mol. Cell. Cardiol. 97, 245-262 (2016).

11. Heineke, J. \& Molkentin, J. D. Regulation of cardiac hypertrophy by intracellular signalling pathways. Nat. Rev. Mol. Cell Biol. 7, 589-600 (2006).

12. Blaustein, M. P. How does pressure overload cause cardiac hypertrophy and dysfunction? High-ouabain affinity cardiac Na 2 pumps are crucial. Am J Physiol Hear. Circ Physiol 313, 919-930 (2017).

13. Zhou, L., Ma, B. \& Han, X. The role of autophagy in angiotensin Il-induced pathological cardiac hypertrophy. $J$ Mol Endocrinol 57, 143-152 (2016).

14. Libby, P., Ridker, P. M. \& Maseri, A. Inflammation and Atherosclerosis. Circulation 105, 1135-1143 (2002).

15. Harrison, D. G. et al. Inflammation, Immunity, and Hypertension. Hypertension 57, 132-140 (2011).

16. Paguissi, F. The role of inflammation in cardiovascular diseases: the predictive value of neutrophillymphocyte ratio as a marker in peripheral arterial disease. Ther Clin Risk Manag 12, 851-860 (2016).

17. Sagar, S., Liu, P. P. \& Cooper, L. T. J. Myocarditis. Lancet 379, 738-747 (2012).

18. Fung, G., Luo, H., Qiu, Y., Yang, D. \& Mcmanus, B. Myocarditis. Circ Res 118, $496-514$ (2016).

19. Heymans, S., Eriksson, U., Lehtonen, J. \& Cooper, L. T. J. The Quest for New Approaches in Myocarditis and Inflammatory Cardiomyopathy. J. Am. Coll. Cardiol. 68, 2348-2364 (2016). 
20. Yajima, T. Viral myocarditis: potential defense mechanisms within the cardiomyocyte against virus infection. Futur. Microbiol 6, 551-566 (2011).

21. Borchert, G. M., Lanier, W. \& Davidson, B. L. RNA polymerase III transcribes human microRNAs. 13, 10971101 (2006).

22. Lee, Y. et al. MicroRNA genes are transcribed by RNA polymerase II. 23, 4051-4060 (2004).

23. Luciano, D. J., Mirsky, H., Vendetti, N. J. \& Maas, S. RNA editing of a miRNA precursor. RNA 10, 11741177 (2004).

24. Guil, S. \& Caceres, J. F. The multifunctional RNA-binding protein hnRNP A1 is required for processing of miR-18a. Nat Struct Mol Biol 14, 591-596 (2007).

25. Davis, B. N., Hilyard, A. C., Lagna, G. \& Hata, A. SMAD proteins control DROSHA- mediated microRNA maturation. Nature 454, 56-61 (2008).

26. Winter, J., Jung, S., Keller, S., Gregory, R. I. \& Diederichs, S. Many roads to maturity : microRNA biogenesis pathways and their regulation. 11, (2009).

27. Verjans, R., van Bilsen, M. \& Schroen, B. MiRNA Deregulation in Cardiac Aging and Associated Disorders. International Review of Cell and Molecular Biology 334, (Elsevier Inc., 2017).

28. Han, P. et al. A long noncoding RNA protects the heart from pathological hypertrophy. Nature 514, 102-6 (2014).

29. Piccoli, M. et al. Inhibition of the Cardiac Fibroblast - Enriched IncRNA Meg3. 575-583 (2017). doi:10.1161/CIRCRESAHA.117.310624

30. Hermans-Beijnsberger, S., Van Bilsen, M. \& Schroen, B. Long non-coding RNAs in the failing heart and vasculature. Non-Coding RNA Res. 3, 118-130 (2018).

31. Micheletti, R. et al. The long noncoding RNA Wisper controls cardiac fibrosis and remodeling. Sci. Transl. Med. 8, 336ra22 (2016).

32. Ounzain, S. et al. CARMEN, a human super enhancer-associated long noncoding RNA controlling cardiac specification, differentiation and homeostasis. J. Mol. Cell. Cardiol. 89, 98-112 (2015).

33. Verjans, R. et al. MicroRNA-221/222 Family Counteracts Myocardial Fibrosis in Pressure Overload-Induced Heart Failure. Hypertension 71, 280-288 (2017).

34. Rooij, E. Van \& Olson, E. N. MicroRNA therapeutics for cardiovascular disease: opportunities and obstacles. Nat Rev Drug Discov 11, 860-872 (2012).

35. Creemers, E. E. \& Rooij, E. Van. Function and Therapeutic Potential of Noncoding RNAs in Cardiac Fibrosis. Circ Res 118, 108-118 (2015).

36. Gomes, C. P. C. et al. The Function and Therapeutic Potential of Long Non-coding RNAs in Cardiovascular Development and Disease. Mol. Ther. Nucleic Acid 8, 494-507 (2017).

37. Verjans, R. et al. Functional Screening Identifies MicroRNAs as Multi-Cellular Regulators of Heart Failure. Sci. Rep. 



\section{Chapter 2}

\section{Long non-coding RNAs in the failing heart and vasculature}

Steffie Hermans-Beijnsberger ${ }^{1}$, Marc van Bilsen ${ }^{1,2}$, Blanche Schroen ${ }^{1}$

1 Department of Cardiology, CARIM School for Cardiovascular Diseases, Maastricht University, Universiteitssingel 50, 6200 MD Maastricht, the Netherlands.

2 Department of Physiology, CARIM School for Cardiovascular Diseases, Maastricht University, Universiteitssingel 50, 6200 MD Maastricht, the Netherlands

Noncoding RNA Res. 2018 Apr 14;3(3):118-130.

doi:10.1016/j.ncrna.2018.04.002. 



\begin{abstract}
Following completion of the human genome, it became evident that the majority of our DNA is transcribed into non-coding RNAs (ncRNAs) instead of protein-coding messenger RNA. Deciphering the function of these ncRNAs, including both small- and long non-coding RNAs (IncRNAs), is an emerging field of research. LncRNAs have been associated with many disorders and a number have been identified as key regulators in the development and progression of disease, including cardiovascular disease (CVD). CVD causes millions of deaths worldwide, annually. Risk factors include coronary artery disease, high blood pressure and ageing. In this review, we will focus on the roles of IncRNAs in the cellular and molecular processes that underlie the development of CVD: cardiomyocyte hypertrophy, fibrosis, inflammation, vascular disease and ageing. Finally, we discuss the biomarker and therapeutic potential of IncRNAs.
\end{abstract}




\section{Introduction}

\section{Non-coding RNAs in Cardiovascular Disease}

Cardiovascular disease (CVD) accounts for the greatest proportion of the mortality rate worldwide, with more than 17 million fatalities attributed to it annually ${ }^{1}$. CVD is complex and includes disorders of the heart and blood vessels. Heart failure (HF) can develop after a myocardial infarction (MI), myocarditis, valvular disease, or hypertension ${ }^{2}$. Moreover, coronary artery disease as a result of chronic inflammation of the vessels, vascular calcification and atherosclerosis, is one of the main risk factors for $\mathrm{HF}^{3}$. The heart responds to these pathological challenges through a series of molecular and cellular changes, collectively referred to as cardiac remodelling ${ }^{4}$. Four main processes are involved in the pathophysiology of cardiac remodelling: hypertrophy, fibrosis, inflammation and vascular disease. However, ageing might be the most important factor contributing to cardiac remodelling and the development of CVD ${ }^{5,6}$.

In the past decades, considerable research has been conducted with patients, in animals, and at the cellular level, with the main focus on protein-coding genes and their transcribed messenger RNA (mRNA) and translated proteins. However, in the current post-genomic, we know that only $2 \%$ of the human genome is transcribed into protein-coding genes, leaving the majority undefined (International Human Genome Sequencing Consortium 2004). In the last 15 years, studies also started to focus on the remaining $98 \%$ of the genome and found that up to $90 \%$ is being transcribed into RNA (non-coding RNAs) ${ }^{7}$. Non-coding RNAs (ncRNAs) can differ in length, from small ncRNAs of less than 200 nucleotides, for example microRNAs (miRNAs), to large ncRNAs with over 200 nucleotides named long ncRNAs (IncRNAs). miRNAs have been described as playing significant roles in cancer development ${ }^{8}$, prognosis ${ }^{9-13}$, neuronal disorders ${ }^{14,15}$, and have central roles in CVD development ${ }^{16-20}$. LncRNAs research only recently came to prominence, with the first functional studies in the early 1990 s $^{21-23}$. Although the first studies examining the role of IncRNAs in the heart were published in 2012 , these studies focussed primarily on cardiac development ${ }^{24,25}$. In this review, we discuss the latest literature concerning the role of IncRNAs in CVD and its associated risk factors.

\section{Classification}

In general, IncRNAs are defined as ncRNAs that have a length $>200$ nucleotides, excluding the known classic ribosomal RNAs ${ }^{26}$. Amaral et al. proposed a slightly different definition: IncRNAs are ncRNAs that may function as either primary or spliced transcripts, independent of small RNAs, excluding the structural RNAs (ribosomal RNA). Here, the length of the IncRNA is not specified as one of the criteria ${ }^{27}$. Therefore, there are also ncRNAs, such as $B C 1$ and snaR, which are actually shorter, yet are still classified as IncRNAs ${ }^{28,29}$.

Even though they lack an open reading frame and do not encode for proteins, there are many similarities between IncRNAs and protein-coding genes. Both are transcribed by RNA polymerase II or III, many are 5'-capped, 3'-end poly-adenylated, and multi-exonic. ${ }^{30,31}$. LncRNAs can regulate gene expression at the transcriptional, as well as the posttranscriptional level ${ }^{32}$. However, classifying IncRNAs in defined subgroups remains challenging. In general, IncRNAs exhibit poorer conservation than protein-coding genes ${ }^{33}$. 
Most IncRNAs will be folded after transcription and create a tertiary structure ${ }^{34}$. It is suggested that this tertiary structure, and not so much their sequence composition, determines their function ${ }^{35}$. Still, recognizing and classifying the structure of IncRNAs remains in its infancy and therefore other classification methods have been proposed.

LncRNAs can be classified according to their features: by their effect on DNA sequences, by their mechanisms of function (transcriptional regulation, post-transcriptional regulation, or other functions), by their targeting mechanism (based on the types of interactions they make with their targets, and the consequences of these actions), and most commonly, by their genomic location [32]. Based on their genomic location, IncRNAs can be classified as: (1) sense, transcribed from the same strand and the same direction as the surrounding proteincoding genes, they can be both (multi-)exonic and intronic; (2) antisense, transcribed from the opposite strand of surrounding protein-coding genes, also with the possibility of being both (multi-)exonic and intronic; (3) intronic, located entirely in intronic regions of a proteincoding gene; (4) intergenic, located in between two protein-coding genes, transcribed in the same direction; (5) bidirectional, located within $1 \mathrm{~kb}$ of the promoter region of a proteincoding gene, but transcribed from the opposite strand (Figure 1).
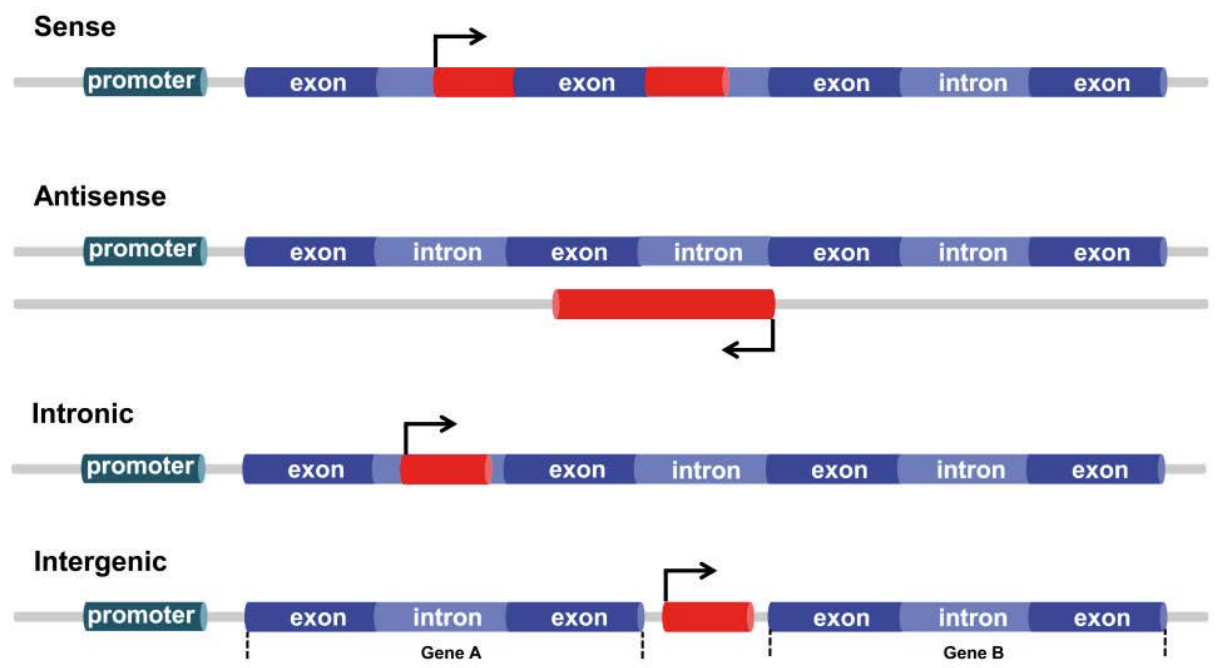

Bidirectional

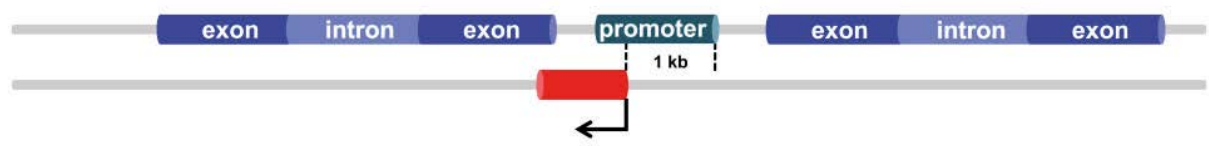

Figure 1: Classification of IncRNAs based on their genomic location. Sense IncRNAs are transcribed from the same strand and in the same direction as their surrounding protein-coding genes; they can be both (multi-)exonic and intronic. Antisense IncRNAs are transcribed from the opposite strand of the protein-coding genes and can also be both (mulit-)exonic and intronic. Intronic IncRNAs are located entirely in intronic regions of a protein-coding gene. Intergenic IncRNAs are located in between two protein-coding genes, and are transcribed in the same direction. Bidirectional IncRNas are located within $1 \mathrm{~kb}$ of the promoter region of a protein-coding gene, but are transcribed from the opposite strand. 


\section{Mode of action of IncRNAs}

Given that IncRNAs have only recently been described, knowledge about their mechanism of action remains limited. By contrast, miRNAs have been studied for many years now and have a clear mode of action: they act by targeting mRNAs in a sequence specific manner and, in this way, repress translation and/or promote degradation of the target mRNA ${ }^{9}$. Based on the expanding knowledge about their cellular function, IncRNAs can be divided into several functional categories: signal, decoy, guide, scaffold, enhancer, and circular IncRNAs (Figure 2) ${ }^{36}$.

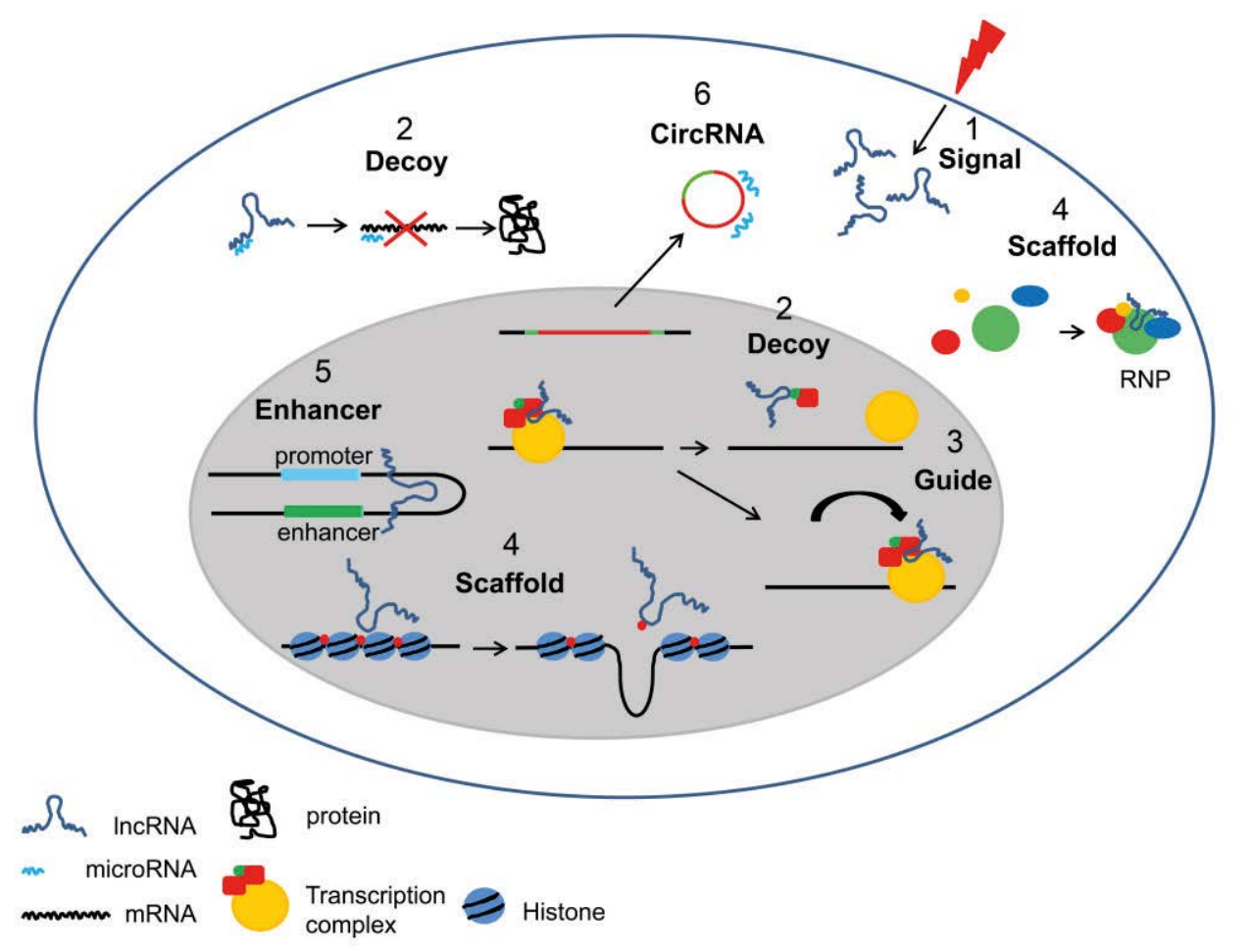

Figure 2: Functions of IncRNAs. 1) Signal IncRNAs are only expressed at specific time points and at specific locations in the cell. 2) Decoy IncRNAs can bind to regulatory factors and microRNAs, and alter their function. 3) Guide IncRNAs regulate gene activation or repression by relocalization of the ribonucleoprotein complex. 4) Scaffold IncRNAs can form similar structures as guide IncRNAs, but they affect the molecular components of the complex itself. 5) Enhancer IncRNAs are produced from enhancer elements and influence the activation of target genes. 6) Circular IncRNAs can interfere with RNA processing, RNA splicing and can act as microRNA sponges.

Signal IncRNAs are only expressed at specific time points and they are localized to certain subcellular regions where they exert their function, for example during development. They can be cell type-specific, and they respond to various stimuli ${ }^{37}$. KCNQ1OT1 and AIR are two IncRNAs that mediate transcription at specific time points during early development, by interacting with chromatin-modifying enzymes ${ }^{38,39}$. Therefore, these signal IncRNAs could 
also be classified as scaffold or decoy IncRNAs. Decoy IncRNAs bind to regulatory factors such as transcription factors, RNA-binding proteins, and chromatin modifiers, altering their biological activity ${ }^{37}$. As an example, telomeric repeat-containing RNA (TERRA) can bind directly to telomerase reverse transcriptase, an enzyme which is part of the telomerase complex, and inhibit its function ${ }^{40,41}$. Metastasis associated in lung adenocarcinoma transcript 1 (Malat1) is another IncRNA which can be categorized as a decoy IncRNA, as it localizes to nuclear speckles where it sequesters splicing factors and thereby affects alternative splicing for a number of pre-mRNAs ${ }^{42}$. In addition, according to the competing endogenous RNA (ceRNA) hypothesis, IncRNAs can function as sponges for certain miRNAs ${ }^{43}$. In this setting, IncRNAs bind to miRNAs and influence the protein translation of the target mRNAs.

There are numerous IncRNAs that have been shown to target miRNAs and in this way affect cellular mechanisms underlying disease ${ }^{44-48}$. Guide IncRNAs regulate gene activation or repression by forming ribonucleoprotein complexes and mediating their localization to specific target sites ${ }^{37}$. Comparable to guide IncRNAs are scaffold IncRNAs which can form similar structures, although they affect the molecular components of the complex itself. Several studies have shown effects of IncRNAs on chromatin complexes and histone modifiers ${ }^{49,50}$. However, whether these are scaffold or guide IncRNAs remains elusive. An alternative mechanism of action has been described, in which enhancer IncRNAs are produced from enhancer elements and influence the activation of target genes ${ }^{51}$. These IncRNAs have been shown to play important regulatory roles, for example in oestrogendependent transcriptional activation ${ }^{52}$.

A fairly new class of ncRNAs, referred to as circular RNAs, are generated by backsplicing of the 5' and 3' ends of a produced RNA, and thereby forming a loop. Due to their circularity, they are very stable and resistant to digestion by exonucleases. They can interfere with RNA processing, regulate splicing, act as miRNA sponges ${ }^{53}$ and have been implicated in disease processes (recently reviewed by Green et al.) ${ }^{54}$. It is debatable whether circular RNAs should be regarded as IncRNAs, or are a different and separate class of ncRNAs. Circular RNAs can have different lengths, ranging from under 100 nucleotides to over $4 \mathrm{~kb}$. In addition, they can be transcribed from the same genomic region as their co-existing IncRNA 54. For example, multiple RNA transcripts can be transcribed from the INK4/ARF locus including the linear IncRNA ANRIL and separate circular RNAs ${ }^{55}$. Therefore, when considering the semantics, it seems to make most sense to classify circular RNAs as a separate class of ncRNAs. Still, the functions of circular RNAs might overlap with those of IncRNAs.

The classification of IncRNAs remains cumbersome and sometimes arbitrary, given for instance that they can be intronic and intergenic at the same time, and can function as decoy and scaffold RNAs simultaneously. Improving knowledge on the tertiary structure of IncRNAs may help to enhance understanding of the function of IncRNAs. This could aid in finding binding partners of IncRNAs and identifying in which molecular pathways they are involved. In addition, knowledge on their tertiary structure will improve the design of tools to knockdown specific IncRNAs and in this way affect cellular processes involved in disease. Another classification system that is successfully used for proteins is subcellular localization. Indeed, cellular fractions have already been subjected to RNA sequencing in order to link 
nuclear- or whole cell localization of IncRNAs with particular functions ${ }^{56}$. Studying their subcellular localization and investigating their interactions with proteins will enhance knowledge about their functions. A broad overview of different techniques to investigate the function of IncRNAs is described by Kashi et al. ${ }^{57}$. This article shows that we might have to reconsider the current classification system and try to improve it or change it completely by concentrating on IncRNAs structure, cellular localization, and binding partners.

\section{LncRNAs in cardiomyocyte hypertrophy}

\section{Cardiac hypertrophic cell signalling}

Cardiomyocyte growth (hypertrophy) can be induced by biomechanical or neurohumoural mechanisms. These processes can be triggered by pathological stimuli, including chronic hypertension, ischaemic disease, viral myocarditis, diabetic cardiomyopathy, or familial cardiomyopathy ${ }^{58,59}$. Cardiomyocyte hypertrophy is a cellular process involving many different signalling pathways (extensively reviewed by Heineke and Molkentin) ${ }^{60}$. In short, cardiomyocytes sense neurohumoral and endocrine hormones such as catecholamines, endothelin-1 (Et-1), angiotensin II (AngII), insulin-like growth factor-I, and cytokines by their membrane-bound (G-protein-coupled) receptors and activate their intracellular signalling pathways ${ }^{60}$. The major signalling pathways described in literature today, include mitogenactivated protein kinase (MAPK), calcineurin-nuclear factor of activated T cells (NFAT), phosphatidylinositol 3-kinase-AKT, Janus kinase (JAK) - signal transducer and activator of transcription (STAT), and chromatin remodelling by histone deacetylases (HDACs) ${ }^{61-64}$. Activation of all these pathways eventually leads to activation of transcription factors or epigenetic changes, which regulate gene expression in the hypertrophied heart ${ }^{65}$. To date several IncRNAs have been interrogated for their role in hypertrophic remodelling (Figure 3).

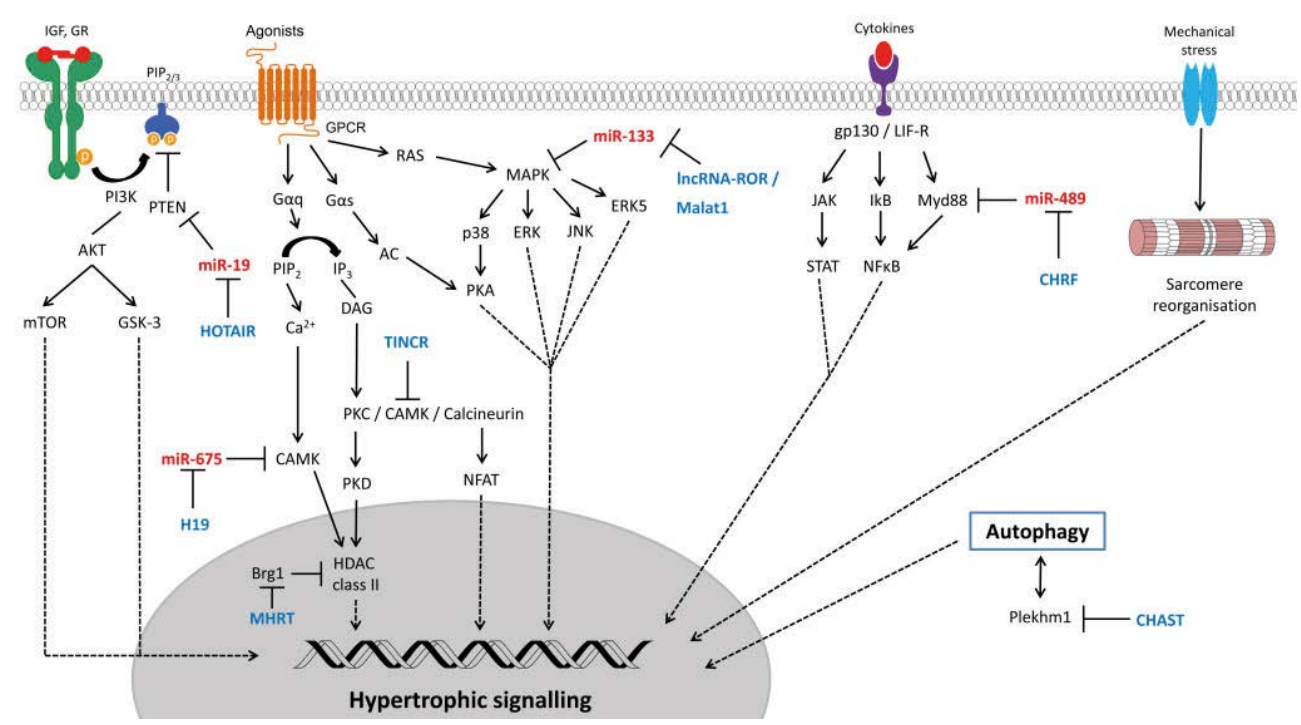


4 Figure 3: IncRNAs affect hypertrophic signalling in cardiomyocytes. Mechanical or neurohormonal triggers can activate receptors on the cardiomyocyte cell membrane. Cardiomyocytes sense these signals, such as agonists (endothelin-1, angiotensin II), IGF-I, and cytokines, that activate intracellular signalling pathways. These pathways include MAPK, calcineurin-NFAT, PI3K-AKT, JAK/STAT, and chromatin remodelling by HDACs. Activation of these pathways initiates hypertrophic growth of the cardiomyocyte. LncRNAs regulate signalling at different levels, by either direct or indirect (possibly via microRNA silencing) inhibition. Abbreviations: Brg-1, brahma-related gene 1; CAMK, Calmodulin-Dependent Protein Kinase; ERK, extracellular-regulated kinases; GCPR, G-protein-coupled receptors; GR, growth factor; GSK-3, Glycogen synthase kinase 3; HDACs, Histone Deacetylases; IGF, insulin-like growth factor; IKB, inhibitors KB; JAK, Janus kinase; JNK, c-jun N-terminal protein kinases; LIF-R, Leukemia Inhibitory Factor Receptor; MAPK, mitogen-activated protein kinase; mTOR, mammalian target of rapamycin; Myd88, Myeloid differentiation primary response 88; NFKB, nuclear factor-KB; NFAT, nuclear factor of activated T; PI3K, phosphatidylinositol 3kinase; $\mathrm{PIP}_{2 / 3}$, phosphorylating phosphatidylinositol-4, 5-bi/tri phosphate; Plekhm1, Pleckstrin homology domaincontaining family $M$ member 1; PKA, protein kinase $A$; PKC, protein kinase $C$; PKD, protein kinase D; PTEN, Phosphatase and tensin homolog; STAT, signal transducer and activator of transcription.

\section{LncRNAs in cardiac hypertrophy}

The first paper describing a role for IncRNAs in cardiac hypertrophy was published in 2014 by Han et al. ${ }^{66}$. These authors identified a new antisense transcript of myosin heavy chain 7 (Myh7) formed by alternative splicing, named Myosin Heavy Chain Associated RNA Transcripts (MHRT). MHRT is cardiac specific and highly expressed in the mouse and human adult heart. It functions by antagonizing brahma-related gene 1 (Brg1), blocking its recognition site for genomic DNA, and thereby influencing gene regulation by chromatin remodelling. The MHRT-Brg1 feedback circuit appears to be crucial for heart function and potentially has a conserved role in humans. The human orthologue of MHRT also overlaps $\mathrm{MYH7}$ on the opposite strand, which makes it an interesting IncRNA for further research. MHRT has already been suggested as a biomarker for predicting HF in humans ${ }^{67}$.

More recently, the IncRNAs cardiac hypertrophy-associated transcript (Chast) and cardiachypertrophy-associated epigenetic reglator (Chaer) were identified ${ }^{68,69}$. Both are increased upon pressure overload-induced HF in mice and are conserved in humans. Chast overexpression induced cardiomyocyte hypertrophy in vitro and in vivo, whereas silencing of Chast attenuated cardiac remodelling after pressure overload. It was suggested that Chast functions by a cis-regulatory action on the gene located on the opposite strand: Pleckstrin homology domain-containing protein family $M$ member 1 , an autophagy regulator ${ }^{70}$. However, the exact mechanism of action remains to be elucidated and the connection to cardiac hypertrophy is at the moment unclear. Chaer, on the other hand, functions through the direct interaction with the catalytic subunit of a protein, polycomb repressor complex 2 (PRC2), and influencing the chromatin remodelling function of PRC2. PRC2 can bind to genomic loci and inhibit the methylation of histone H3 lysine 27. In this way, Chaer can affect epigenetic reprogramming of the expression of genes involved in cardiac hypertrophy. Therefore, both Chaer and Chast play a key role in the development of cardiac hypertrophy and failure, though their mechanism of action differs significantly.

Another IncRNA that seems to play an important role in cardiac hypertrophy is terminal differentiation-induced ncRNA (TINCR). Forced expression of this IncRNA attenuated cardiac hypertrophy in mice, and decreased calmodulin-dependent protein kinase II (CAMKIIס) expression by directly targeting Enhancer of zeste $2(\mathrm{EZH} 2)^{71}$. EZH2 is a methyltransferase that plays a fundamental role in $\mathrm{H} 3 \mathrm{~K} 27 \mathrm{me} 3$ modification and can bind to 
the CAMKIIס promoter region to regulate its expression ${ }^{72}$. The IncRNA TINCR is annotated in human, and has been exclusively studied in cancer where it affects KLF2 mRNA stability and thereby cyclin-dependent kinases ${ }^{73}$. Nonetheless, IncRNA TINCR regulates cardiac hypertrophy in mice and might be an interesting therapeutic target.

Malat1 is a well-conserved IncRNA which is highly expressed in many tissues, including the heart. Malat1 is involved in mRNA splicing and reduces revascularization capacity in ischaemia ${ }^{42,74,75}$. Surprisingly, knocking out Malat1 in mice is not detrimental and they have normal development ${ }^{76-78}$. In addition, pathological cardiac remodelling by transverse aortic constriction (TAC) is similar in Malat1 knock-out mice as in wildtype mice ${ }^{79}$. However, in these mice only the first two exons (including start codon) are knocked-out, potentially leaving the possibility to produce the 3'-end transcript mascRNA (unpublished observations).

Taken together, emerging evidence indicates that multiple IncRNAs are implicated in the regulation of cardiac hypertrophy. The majority of the IncRNAs described above are working via a scaffold-based mechanism, in which they prevent targets from exerting their functions.

\section{CeRNAs in cardiac hypertrophy}

The ceRNA hypothesis proposed by Salmena et al. states that RNA transcripts (mRNA, pseudogenes, IncRNAs) communicate via miRNA response elements (MREs) ${ }^{43}$. In the conventional way of thinking, miRNAs regulate mRNA levels. This hypothesis, on the other hand, suggests that 1) RNAs can regulate specific miRNAs by binding them and reduce their availability and activity, and 2) RNAs can bind to mRNAs and block the binding site of miRNAs. It has already been demonstrated that the pseudogene PTENP1 regulates protein levels of phosphatase and tensin homologue (PTEN) by binding to MREs of the mRNA of PTEN, hence preventing miRNA-mediated repression of PTEN expression ${ }^{80}$.

Several recent studies provide evidence that some IncRNAs indeed act via miRNAs, thus supporting the ceRNA hypothesis. The IncRNA cardiac hypertrophy related factor $(C H R F)$ is upregulated in cardiomyocyte hypertrophy where it scavenges miRNA-489 and thereby indirectly regulates the levels of the target gene myeloid differentiation primary response gene 88 (Myd88) ${ }^{81}$. Previous studies had already shown that the Toll-like receptor 4mediated, MyD88-dependent, nuclear factor-kB (NFkB) pathway is involved in cardiomyocyte hypertrophy ${ }^{82}$. Similar roles have been attributed to the IncRNA myocardial infarction-associated transcript (MIAT) and IncRNA H19, which act by sponging miRNA-150 and miRNA-675 respectively, affecting CAMKIIס levels in cardiomyocytes ${ }^{83,84}$. CAMKIIסmediated HDAC inactivation has been well studied in cardiac hypertrophy and is a key modulator in the development of $\mathrm{HF}^{85-87}$. All these IncRNAs were investigated in the context of cardiac hypertrophy, but none of these studies elaborated on the underlying molecular mechanism.

Another central pathway in cardiac growth is the MAPK signalling pathway. Ligand binding to G-protein-coupled receptors, reactive oxygen species (ROS) and environmental stress, activate a signalling cascade of proteins that ultimately results in activation of the transcription factors, which regulate cardiac gene expression ${ }^{61,63}$. 
LncRNA human large intergenic non-coding RNA ROR (IncRNA-ROR) influences MAPK signalling by acting as a sponge for miRNA-133 ${ }^{88}$. miRNA-133 has been extensively studied in cardiac hypertrophy and has been implicated in targeting key regulators of cardiac disease includig serum response factor (SRF), connective tissue growth factor, CDC42, and many others ${ }^{89}$. In addition, IncRNA Malat1 has also been shown to act as a ceRNA by scavenging miRNA-133, and thereby affecting myocyte differentiation by SRF ${ }^{90}$. As well as MAPK signalling, PI3K-AKT signalling is very important in cardiac hypertrophy ${ }^{62,64}$. LncRNA HOTAIR may function as a sponge to modulate PTEN levels via miRNA-19, connecting another IncRNA with the miRNA-mRNA inhibiting concept ${ }^{91}$. miRNA-19 can inhibit PTEN expression, a protein which is directly linked to PI3K-AKT signalling. The collective findings suggest that several IncRNAs are important regulatory factors in cardiac hypertrophy through ceRNA activity. Still, the exact mode of action of these IncRNAs is unclear and needs to be further investigated.

\section{Transcriptome analysis of IncRNAs in cardiac hypertrophy}

In addition to the limited number studies on the roles of known IncRNAs in cardiac hypertrophy (described above), several groups have performed transcriptome analyses of the hypertrophic and/or failing heart to identify (new) IncRNAs that could be relevant for the development of cardiac hypertrophy ${ }^{92-96}$. These studies include microarray analysis or RNA sequencing of human ischaemic heart failure tissue compared to embryonic mouse heart tissue ${ }^{97}$, human iPSC-derived cardiomyocytes subjected to endothelin-1 ${ }^{93}$, mouse hearts one and four weeks after TAC ${ }^{92,95}$, rat hearts four weeks after TAC ${ }^{98}$ and mouse hearts 1 week after $\beta$-adrenergic receptor activation by isoproterenol injection ${ }^{94}$. Interestingly, Matkovich et al. concluded that IncRNA expression responses upon TAC are surprisingly mild, with only 17 differentially expressed IncRNAs as compared to sham hearts ${ }^{92}$. In sharp contrast, 1 week of $\beta$-adrenergic receptor activation resulted after 1 week in a tremendous change in cardiac IncRNA profiles, with over a 1000 IncRNAs up- and down-regulated as compared to saline injection ${ }^{94}$. Similar numbers of differential IncRNAs were identified in mouse hearts upon 4 weeks of TAC by Sun et al. ${ }^{95}$. These huge deviations in numbers of differentially expressed genes may not be biologically meaningful, given the diversity of (statistical) analyses used by these studies. Unfortunately, the poor annotation of IncRNAs makes it currently unfeasible to compare studies and to identify any potential overlap.

A further confounding factor is that transcriptome analysis of cardiac tissue includes transcripts from all the cell types in the heart, with cardiomyocytes outnumbered by noncardiomyocytes at least $1: 3$ in the adult mammalian heart ${ }^{99}$. This makes it challenging to identify IncRNAs that are cell type-specific and are involved in cell type-specific processes, in particular those IncRNAs that are low expressed. To overcome this, fluorescence activated cell sorting or magnetic-activated sorting of cell type specific nuclei can be applied 100,101 . Both methods could be useful to identify cell type-specific IncRNAs. However, one should keep in mind that the process of isolating heart cells can provoke a stress reaction (for example using Langendorff method or during cardiac neonatal cell isolation), which might influence gene expression. When sorting solely cellular nuclei this can be widely prevented, since they originate from snap frozen tissue and are isolated using enzymatic inhibitors ${ }^{102}$. 
Few studies so far have then gone on to further characterise IncRNAs identified by transcriptome analyses. LncRNA BC088254 was identified upon TAC in rat hearts ${ }^{98}$, and found to correlate with prohibitin 2 (PHB2) expression, a membrane-bound mitochondrial protein important in mitochondrial fission and apoptosis in cardiomyocytes ${ }^{103}$. It was suggested that IncRNA BC088254, via its effect on PHB2, plays an important role in the process of mitochondrial dynamics and function. However, exactly how these factors affect cardiac disease and specifically cardiac hypertrophy, remain elusive. In addition, CARMEN, identified by transcriptome analysis and upregulated in human HF, turns out to be a crucial regulator for cardiac cell differentiation and homeostasis, and acts as a super enhancerassociated IncRNA ${ }^{97}$. This class of enhancers epigenetically regulates key elements of the transcription machinery during (disease-associated) cellular processes. During cardiac differentiation the expression pattern of Braveheart (Bvht), a IncRNA originally identified in mouse ${ }^{104}$, was comparable to that of CARMEN. As such, it will be interesting to explore the role of both transcripts in the development of HF.

In summary, these studies revealed that IncRNAs are of significance during the development cardiac hypertrophy and failure. If the differential expressed IncRNAs upon cardiac hypertrophy and remodelling indeed outnumber the 1000 , as suggested by some studies described above, a huge number of new IncRNAs remains to be explored. It is difficult to establish whether there is overlap in newly identified IncRNAs between studies, mainly because of the use of different IncRNA annotations. Above all, the exact mechanism of action of the IncRNAs putatively implicated in cardiac disease still remains to be elucidated.

\section{LncRNAs in cardiac fibrosis}

\section{Cardiac fibrotic signalling}

Cardiac remodelling is a pathological process in which, besides cardiomyocyte hypertrophy, cardiac fibroblasts (CFs) proliferate, differentiate into myofibroblasts, and produce extra cellular matrix (ECM) proteins. Excessive ECM production can lead to increased ventricular stiffness and impaired contractility, which can progress into HF ${ }^{105}$. CFs regulate ECM homeostasis, which provides a structural scaffold for cardiomyocytes and promotes efficient electric conduction throughout the myocardium ${ }^{106}$. Myocardial injury can cause a series of cellular responses: activation of the inflammatory response, proliferation of CFs, and thickening of the myocardium. These processes are partly regulated by CFs. CFs can produce pro-inflammatory cytokines and pro-fibrotic factors, which lead to an increase in proliferation and ECM production (fibrosis). There are two types of fibrosis: interstitial fibrosis and perivascular fibrosis. In mouse pressure overload models, the initial response of the heart to the increased pressure is fibroblast hyperproliferation inciting interstitial fibrosis, which over time will be followed by replacement fibrosis ${ }^{107}$. In ischaemic/reperfusion models or MI models, the acute inflammatory response causes excessive cardiomyocyte cell death, which is directly filled up by replacement fibrosis ${ }^{108}$.

Currently, Transforming Growth Factor (TGF)- $\beta$ is believed to be the most important profibrotic factor and TGF- $\beta$ receptor-mediated signalling is thought to play a major role in cardiac pathological fibrosis ${ }^{109}$. Both the canonical and non-canonical TGF- $\beta 1$ signalling 
pathways lead to transcriptional regulation of pro-fibrotic genes ${ }^{110}$. In addition, the reninangiotensin system, adrenergic signalling, RhoA - myocardin-related transcription factor SRF signalling, growth factors, integrins and many additional pathways, have been described to influence the fibrotic response in CFs ${ }^{105}$. Which IncRNAs are involved, and how they affect these pathways, is still unclear. However, several IncRNAs were identified in ischaemic heart disease and shown to have a role in fibrosis ${ }^{44,111-114}$. These studies are described in the next paragraph.

\section{LncRNAs in ischaemic heart disease}

Acute $\mathrm{MI}(\mathrm{AMI})$ can occur when an atherosclerotic plaque ruptures, which results in an intraluminal thrombus in one or more of the coronary arteries. This causes extreme ischaemia in the surrounding cardiac tissue, ultimately leading to myocardial cell death. Once the cardiac tissue is dead, it will be cleaned up by surrounding and invading cells, and CFs will replace the necrotic tissue with ECM proteins, primarily collagen. Several IncRNAs have been investigated specifically in the setting of $\mathrm{Ml}$ and have been shown to play an important role in the post-MI remodelling process.

MIAT was discussed earlier already in relation to cardiac hypertrophy. MIAT also plays a role in the cardiac responses upon $\mathrm{MI}$, including fibrosis ${ }^{115}$. MIAT is upregulated in a mouse model of $\mathrm{Ml}$ and knocking it down improves cardiac function. In addition, lowering MIAT expression inhibits collagen production and CF proliferation, which results in less interstitial fibrosis after MI. These authors propose a mechanism in which MIAT functions as a sponge for miRNA-24 in CFs.

Piccoli et al. were the first to study the role of CF-enriched IncRNAs in the development of cardiac fibrosis ${ }^{116}$. LncRNA maternally expressed gene 3 (Meg3) was downregulated in CFs during late cardiac remodelling, where it modulates the expression of matrix metalloproteinase-2 (Mmp-2) in a p53-dependent manner. Meg3 blocks the recognition site for $\mathrm{p} 53$ on the Mmp2 promoter as shown by immunoprecipitation. Depleting Meg3 levels in vivo after TAC attenuated cardiac fibrosis and improved diastolic function. Previously it has been shown that Meg3 recruits components of PRC2 to specific genomic locations, acting as a guide IncRNA ${ }^{117,118}$.

Recently, is was demonstrated that another IncRNA, Wisp2 super-enhancer-associated RNA (Wisper), has a major effect on the development of cardiac fibrosis ${ }^{119}$. Wisper was found to influence CF proliferation, migration and survival, and in this way controls CFspecific gene programs. Depleting Wisper levels in vivo attenuated Ml-induced fibrosis and improved cardiac function. More importantly, reducing the levels of Wisper two days post-MI improved cardiac function, thereby demonstrating therapeutic potential of this IncRNA.

Several other IncRNAs have been implicated in MI, including myocardial infarctionassociated transcript 2 (MIRT2) ${ }^{120}$, NONRATT021972 ${ }^{121,122}$, and MHRT ${ }^{123}$. In addition, transcriptome analysis of heart tissue identified novel IncRNAs that are possibly involved in processes underlying cardiac ischaemic injury in mouse and human ${ }^{124,125}$. However, the precise role of these IncRNAs in cardiac fibrosis and ischaemic heart disease remains elusive. 
LncRNAs are also under consideration as potential biomarkers of HF or specific underlying pathophysiological processes including fibrosis. Vausort et al. showed that IncRNAs might serve as biomarkers for acute $\mathrm{Ml}$ and possibly help predicting outcome. Levels of IncRNAs ANRIL, KCNQ1OT1, MIAT and MALAT1 in the blood of AMl patients can predict left ventricular dysfunction ${ }^{126}$. Another study showed that IncRNA HOTAIR is decreased in serum of AMI patients compared to healthy controls. HOTAIR has a possible cardioprotective function by regulating apoptosis via miRNA-1 ${ }^{127}$. Still, IncRNAs serving as biomarkers have a long way to go before, if ever, becoming clinically applicable, in particular since their circulating levels are extremely low.

\section{LncRNAs in cardiac cell death}

Apoptosis and necrosis are the two main mechanisms by which cell death occurs. Cell death is an important characteristic of ischaemic heart disease. During ischaemic stress in the heart, there is a lack of oxygen delivery to the heart, which causes cardiomyocyte cell death. Multiple studies focussed on the role of IncRNAs in cell death, and how they affect ischaemic injury of the myocardium ${ }^{128-133}$.

Although autophagy was initially thought to be a cell survival process, it is now being linked to both apoptosis and necrosis, serving as both pro-survival and pro-cell death regulator ${ }^{134}$. Through autophagy, cytoplasmic components get recycled. In the heart, autophagy is altered upon ischaemic stress, but also in cardiac hypertrophy ${ }^{135,136}$. Autophagy is controlled by autophagy related genes (ATG), many of which are involved in autophagosome formation ${ }^{137}$. A newly identified IncRNA, named autophagy promoting factor (APF), regulates one of the ATG genes. APF acts as a ceRNA and regulates ATG7 expression, and subsequently cardiac autophagy via miRNA-188. In this way, APF is able to regulate autophagy and cell death in the heart after $\mathrm{Ml}^{138}$. It should be noted, however, that APF is poorly conserved across species, which makes translation to the human situation difficult. Furthermore, APF is expressed at very low levels, problematizing its potential as biomarker. A new IncRNA which is associated with cell death, is $\beta$-secretase- 1 antisense transcript (BACE1-AS). BACE1-AS was upregulated in $\mathrm{HF}$ patients with ischaemic cardiomyopathy compared to controls ${ }^{139}$. BACE1-AS induces $\beta$-secretase-1 (BACE1) expression, as well as, $\beta$-amyloid peptide accumulation. Since increased levels of $B A C E 1-$ $A S$ and $\beta$-amyloid induce toxicity in endothelial cells and cardiomyocytes, the BACE1$A S / B A C E 1 / \beta$-amyloid pathway was considered to have detrimental effects on the cardiovascular system.

Besides its roles in chromatin remodelling during cardiac hypertrophy, IncRNA MHRT is implicated in AMI, and plays a role in $\mathrm{H}_{2} \mathrm{O}_{2}$-induced cardiomyocyte apoptosis ${ }^{123} \cdot \mathrm{H}_{2} \mathrm{O}_{2}$ exposure serves as an in vitro model to study apoptosis, and a way to investigate this pathway for the purpose of ischaemic disease. Several IncRNAs interfere with this pathway and contribute to the current knowledge about ischaemia/reperfusion injury. KCNQ1OT1 silencing prevents increased expression of inflammatory factors, apoptosis-related proteins, and p38 MAPK/NF-kB pathway-related proteins, upon ischaemia-reperfusion injury in cardiac muscle cells ${ }^{140}$. In addition, Urothelial carcinoma-associated 1 (UCA1) is a IncRNA which negatively correlates with $\mathrm{p} 27$, a known tumour suppressor gene involved in caspase 3 activity and cellular apoptosis ${ }^{141}$. The IncRNA necrosis-related factor (NRF) acts on a 
different pathway leading to cell death, as the name suggests. Necrosis in cardiomyocytes is induced by activating a necrosis-inducing complex, consisting of serine/threonine-protein kinase 1 (RIPK1) and 3 (RIPK3). NRF acts as an endogenous sponge, thereby repressing the action of miRNA-873, and regulating the RIPK1/RIPK3-necrosis pathway ${ }^{142}$.

Although limited data is available, most of the IncRNAs found to be involved in cardiac fibrosis up to now, act as ceRNA, and affect cardiac fibrosis and apoptosis indirectly through their interaction with miRNAs. Some of them have potential to act as therapeutic targets for treating cardiac disease.

\section{LncRNAs in cardiac inflammation}

One of the first responses of the body to injury is inflammation. In addition, chronic lowgrade inflammation is a hallmark of metabolic syndrome and its associated conditions, including hypertension, diabetes and obesity, which are important risk factors for HF development. Inflammation, whether as an acute response to injury or the result of a more chronic systemic disease state, is one of the key processes involved in the development of HF. Cardiac inflammation has been mostly studied in myocarditis, sepsis, ischaemia and reperfusion, and allograft rejection ${ }^{143}$. Invading pathogens can cause acute inflammation in the heart (myocarditis) and sepsis with possible cardiac death. The term "septic cardiomyopathy" defines an acute and reversible status with left ventricular systolic dysfunction ${ }^{144}$. During a septic shock, endotoxins like lipopolysaccharide (LPS) activate the production of pro-inflammatory cytokines such as Tumour necrosis factor- $\alpha$ (TNF- $\alpha$ ), and interleukins. HOTAIR, a well-studied IncRNA, seems to play a role in the heart during sepsis. HOTAIR silencing can improve cardiac function during sepsis in mice, and is proposed to exert its effect via inhibition of NFKB and TNF- $\alpha^{145}$. In addition, LPS-induced sepsis increased the expression of Malat1 in the heart. Increased Malat1 levels in LPSstimulated cardiomyocytes control the expression of TNF- $\alpha$, partly via serum amyloid antigen $3^{146}$. In addition, myocardial infarction-associated transcript 1 (MIRT1) was shown to have a role in cardiomyocyte apoptosis and inflammatory cell infiltration in the heart. Suppressing MIRT1 levels attenuated injury in an AMI mouse model, partly by affecting the NFKB pathway ${ }^{147}$. Altogether, HOTAIR, Malat1 and MIRT1 seem to play a role in the development and progression of inflammation, though their mode of action remains largely elusive.

Cardiac inflammation also occurs during allograft rejection after heart transplantation. The innate and adaptive immune responses play an important role in these patients, and IncRNAs have been studied to regulate the immune response-related genes in B and T cells 148,149. Gu et al. identified differentially expressed IncRNAs after allograft rejection in an allogeneic and syngeneic mouse heart transplantation model, and generated a IncRNAmRNA coexpression network. They found two IncRNAs, ncRNA-A930015D03Rik and mouselincRNA1055, that correlated with the Th1 response after transplantation. In differentiated Th1 cells in vitro, they show that knockdown of these two IncRNAs can regulate the immune response by suppressing IL-12R $\beta 1$, Interferon- $\gamma$, and TNF- $\alpha$ expression. In addition, detection of these IncRNAs in peripheral blood lymphocytes indicates their potential as possible biomarkers of cardiac inflammation ${ }^{150}$. 
These studies show the role of IncRNAs in cardiac inflammation with the main focus on sepsis and the immune response to allografts. Nonetheless, cardiac inflammation plays a much broader role in the transition towards $\mathrm{HF}^{151}$. Therefore, future studies are warranted to identify IncRNAs playing central roles in cardiac inflammation, leading to $\mathrm{HF}^{152}$.

\section{LncRNAs in vascular disease}

Chronic hypertension, atherosclerosis, and peripheral vascular disease are important vascular risk factors for HF development. They can cause vascular remodelling, a process that leads to vascular dysfunction and is controlled by many different factors, including inflammatory cytokines, hemodynamic stimuli, and proliferation and migration of endothelial cells, pericytes, fibroblasts, and vascular smooth muscle cells ${ }^{153,154}$.

\section{Endothelial cell functions controlled by IncRNAs}

Up to now, several IncRNAs have been identified that play a role in endothelial cells, all regulating angiogenic function. Fiedler et al. identified two intergenic IncRNAs, LINC00323 and MIR503HG, to be upregulated in endothelial cells during hypoxia ${ }^{155}$. Endothelial loss of these hypoxia-driven IncRNAs impaired cell-cycle control and inhibited capillary formation. Still, more in-depth mechanistic studies are needed to fully understand the mode of action of these IncRNAs. Moreover, these IncRNAs are poorly conserved, challenging the in vivo study of these IncRNAs in vascular disease in different species models. The third IncRNA linked to endothelial cell function, MANTIS, has been shown to interact with $\operatorname{Brg} 1$ in the nucleus, regulating the expression of endothelial genes and facilitating angiogenic sprouting ${ }^{156}$. MANTIS levels are under the control of the histone demethylase JARID1B, and act as a scaffolding IncRNA within a chromatin-remodelling complex, mediating and directing endothelial gene transcription in order to control endothelial cell function.

\section{Perivascular cell functions controlled by IncRNAs}

Next to endothelial cells, perivascular cells, including smooth muscle cells and pericytes, also play pivotal roles in vascular remodelling in response to hypoxia or other hemodynamic stimuli. Silencing of the hypoxia-induced IncRNA MALAT1 caused proliferation and migration of human pulmonary artery smooth muscle cells. Silencing of MALAT1 in a mouse model of hypoxia-induced pulmonary hypertension attenuated cardiac hypertrophy, this effect could not be linked to the vascular smooth muscle cell function of MALAT1 ${ }^{157}$. In an earlier study, MALAT1 KO mice showed no differences as compared to WT littermates in pressure overload-induced cardiac left ventricular hypertrophy ${ }^{79}$. Taken together, the vascular function of MALAT1 requires further studying, in particular, in in vivo pathophysiological settings.

One of the first IncRNAs with a potential role in the vasculature was Inc-Ang362. This IncRNA was upregulated in response to Angll treatment in rat vascular smooth muscle cells, and knocking it down reduced cell proliferation ${ }^{158}$. Unfortunately, no further pathophysiological insights into the potential role of this Inc-Ang362 have emerged since then. It is noteworthy, that Inc-Ang362 may be the host transcript for miRNA-221 and -222. Conceivably, the cellular function of Inc-Ang362 may be attributed to these miRNAs, which are both important in cell proliferation ${ }^{159,160}$. 
Only one paper so far has reported on a role for a IncRNA in pericyte function. Pericytes surround endothelial cells in the smaller vessels and capillaries, where they control the endothelial permeability and angiogenesis. Hypoxia-Induced Endoplasmic Reticulum Stress Regulating IncRNA (HypERInc) was induced by hypoxia in human primary pericytes, and modulates pericyte differentiation, proliferation, and endothelial permeability ${ }^{161}$. Loss of HypERInc resulted in enhanced ER stress in pericytes. Interestingly, ER stress has been proposed to play a major role in cardiovascular pathology and ageing. In addition, these authors observed downregulation of HypERInc levels in human failing hearts. The exact molecular role of HypERInc in ER stress remains to be identified, although the effects on pericytes suggest a role in vascular remodelling. Also, the exact role of this IncRNA in cardiovascular pathophysiology remains to be addressed, a task that is complicated, as for many IncRNAs, by the poor sequence conservation of HypERInc.

\section{LncRNAs in ageing}

Ageing is a dynamic process affecting all living beings. The increasing lifespan of humans has led to a parallel increase in the incidence of CVD. By 2020, over 20 million people will die annually due to CVD. Many physiological processes are involved in ageing; here we will focus on their effect on the heart and vessels. Cardiac ageing increases the incidence of atherosclerosis, hypertension, MI, and stroke ${ }^{162-165}$. Characteristics of cardiac ageing include pathological remodelling of the myocardium (hypertrophy) with decreased diastolic function. In the vasculature, increased vessel stiffness and impaired endothelial function, are features of ageing ${ }^{166}$. Our previous paragraphs describe IncRNAs involved in most of the processes involved in ageing (Table 1). Hypertrophy, fibrosis, inflammation, and vascular diseases, are processes co-presented with increased age, either individually or collectively. 
Table 1: IncRNAs associated with the cellular processes involved in the development of CVD

\begin{tabular}{|c|c|c|c|c|c|}
\hline IncRNA & Risk factor CVD & Expression & Species & Target & Reference \\
\hline \multirow[t]{2}{*}{ MHRT } & Hypertrophy & $\downarrow$ upon TAC & Mouse & Brg1 & 62 \\
\hline & Fibrosis & $\uparrow$ in $\mathrm{AMI}$ & Human & $?$ & 118 \\
\hline Chast & Hypertrophy & $\begin{array}{l}\uparrow \text { upon TAC } \\
\uparrow \text { in AOS }\end{array}$ & $\begin{array}{l}\text { Mouse } \\
\text { Human }\end{array}$ & Plekhm1 & 64 \\
\hline Chaer & Hypertrophy & $\downarrow$ upon TAC & Mouse & PRC2 & 65 \\
\hline TINCR & Hypertrophy & $\downarrow$ upon TAC & Mouse & $\mathrm{EZH} 2$ & 67 \\
\hline CHRF & Hypertrophy & $\uparrow$ upon Angll & Mouse & miR-489 & 77 \\
\hline \multirow[t]{2}{*}{ MIAT } & Hypertrophy & $\uparrow$ upon Angll & Mouse & miR-150 & 79 \\
\hline & Fibrosis & $\uparrow$ upon Ml & Mouse & miR-24 & 110 \\
\hline$H 19$ & Hypertrophy & $\uparrow$ upon TAC & Mouse & miR-675 & 80 \\
\hline IncRNA-ROR & Hypertrophy & $\uparrow$ upon TAC & Mouse & miR-133 & 84 \\
\hline \multirow[t]{3}{*}{ HOTAIR } & Hypertrophy & $\downarrow$ upon TAC & Mouse & miR-19 & 87 \\
\hline & Fibrosis & $\downarrow$ in AMI & Human & miR-1 & 122 \\
\hline & Inflammation & $\uparrow$ upon sepsis & Mouse & $?$ & 140 \\
\hline CARMEN & Hypertrophy & $\begin{array}{l}\uparrow \text { upon Ml } \\
\uparrow \text { in DCM / AOS }\end{array}$ & $\begin{array}{l}\text { Mouse } \\
\text { Human }\end{array}$ & $\begin{array}{l}\text { SUZ12 / } \\
\text { EZH2 }\end{array}$ & 93 \\
\hline Meg3 & Fibrosis & $\downarrow$ upon TAC & Mouse & Mmp-2 & 111 \\
\hline Wisper & Fibrosis & $\begin{array}{l}\uparrow \text { upon MI } \\
\uparrow \text { in AOS }\end{array}$ & $\begin{array}{l}\text { Mouse } \\
\text { Human }\end{array}$ & TIAR & 114 \\
\hline MIRT1 & Fibrosis & $\uparrow$ upon Ml & Mouse & ? & 142 \\
\hline$A P F$ & Fibrosis & $\uparrow$ upon I/R & Mouse & miR-188 & 133 \\
\hline BACE1-AS & Fibrosis & $\begin{array}{l}\uparrow \text { in ischaemic HF } \\
\uparrow \text { upon Ml }\end{array}$ & $\begin{array}{l}\text { Human } \\
\text { Mouse }\end{array}$ & $\begin{array}{l}\text { BACE } 1 / \beta- \\
\text { amyloid }\end{array}$ & 134 \\
\hline Malat1 & Inflammation & $\uparrow$ upon sepsis & Mouse & SAA3 & 141 \\
\hline HypERInc & Vascular disease & $\downarrow$ in $\mathrm{HF}$ & Human & ? & 156 \\
\hline Lnc-Ang362 & Vascular disease & $\uparrow$ upon Angll & Rat & $?$ & 153 \\
\hline
\end{tabular}

Up to now, IncRNAs haven't been investigated specifically in cardiac ageing. However, a number of IncRNAs have been identified to be important in processes involved in ageing, in general. Cellular senescence is one of the key processes of ageing. Replicative senescence, in which cell proliferation is terminally arrested due to progressive telomere erosion, or other DNA-damaging stressors (UV, ROS, stress), can lead to early senescence which later turns into full senescence ${ }^{167}$. Cardiomyocyte senescence is associated with multiple cellular processes, for example, production of ROS by mitochondria. Enhanced ROS production compromises normal cellular function and promotes organ dysfunction, which leads to a decreased lifespan in animals. In addition, the anti-apoptotic and antioxidative stress response in cardiomyocyte contributes to senescence and cardiac ageing 168

While cardiomyocytes are terminally differentiated and largely lack proliferating capacity, telomere shortening in cardiomyocytes is pronounced in HF patients ${ }^{169}$. Telomere erosion, as a result of telomerase knockout, causes telomere shortening upon each cell cycle and results in senescent cells. The noncoding telomeric repeat-containing RNA, TERRA, can base-pair with the RNA template of telomerase and can also bind to the telomerase reverse transcriptase polypeptide to inhibit telomerase activity ${ }^{170,171}$. As a result, cells expressing increased levels of TERRA are pushed into early senescence. Interestingly, unlike most IncRNAs the structure and function of TERRA is conserved among eukaryotes, rendering TERRA-mediated regulation of telomerase a promising therapeutic strategy against cancer and age-associated diseases. 
Abdelmohsen et al. used RNA-sequencing to identify IncRNAs involved in cellular senescence by comparing expressed transcripts in proliferating cells and terminally arrested cells ${ }^{172}$. Interestingly, MALAT1, one of the most widely-studied IncRNAs, was downregulated in senescent cells. This IncRNA has already been shown to be involved in cell cycle arrest; knockdown of MALAT1 blocks the progression of the cell cycle at the G1/S phase, resulting in more senescence-like cells ${ }^{173,174}$.

Age is one of the major risk factors of HF, and studying the role of IncRNAs in cardiac ageing may contribute to a better understanding of the molecular processes that make up the aged and failure-prone heart.

\section{Therapeutic potential of IncRNAs}

Current HF therapy is based on (a combination of) renin-angiotensin-aldosterone system blockers and $\beta$-blockers. Although these medical treatments are quite successful, the mortality rate of HF patients within 2,5 years is still over $40 \%{ }^{175}$. Accordingly, there is a need for alternative therapies. NcRNAs provide an interesting class of molecules for therapeutic use. As outlined in this review, they are involved in a number of crucial processes related to the initiation or progression of disease. In addition, ncRNAs can be targeted by sequence-specific antisense oligonucleotides (ASOs) or small interfering RNAs (siRNAs). Both ASOs and siRNAs act via the Watson-Crick base pairing principle, but differ in their structure ${ }^{176}$. One of the most widely used ASOs for the inhibit IncRNAs are GapmeRs, single stranded antisense oligonucleotides that bind to their target RNA by specific recognition of a complementary sequence within the RNA ${ }^{177,178}$. The resulting double-stranded DNA:RNA heteroduplex causes the activation of RNAse $\mathrm{H}$, which mediates cleavage of the duplex and subsequent degradation of the full-length IncRNA ${ }^{177,179}$. On the other hand, siRNAs consist of two RNA strands, an antisense (or guide) strand and a sense (or passenger) strand, which form a duplex of 19 to $25 \mathrm{bp}$ in length. This RNA duplex associates with the RNA-induced silencing complex (RISC), the passenger strand is lost, and the guide strand cooperates with RISC to bind complementary RNA. The RISC complex mediates cleavage and degradation of the target RNA ${ }^{180}$. GapmeRs and siRNAs are examples of ASOs that are used to study the effect of IncRNAs in vitro and in vivo. The application of GapmeRs and siRNAs to knockdown IncRNA expression was already successful in various studies, showing their effect in cells and in animal models ${ }^{68,75,181-184}$. Furthermore, the first clinical trial has been launched using siRNAs against a specific IncRNA to modulate the Notch pathway and thereby regulatory B cell function, in patients with thymoma and autoimmune diseases (NCT02948855; Clinical trial database from US National Library of Medicine).

In addition to the possible therapeutic potential to target IncRNAs, a number of clinical trials are ongoing and are investigating the application of IncRNAs as biomarkers (NCT02304471; NCT03268135; NCT03152630; NCT02602808; NCT03000764; NCT03299335; NCT03279770; NCT03225183; NCT03076580). Interestingly, four out of these nine studies are being performed in patients with CVD, including heart failure, aortic stenosis, and atherosclerotic vascular disease (NCT03268135; NCT03279770; NCT03225183; NCT03076580; Clinical trial database from US National Library of Medicine). 
The prospect of IncRNAs as biomarkers is moving forward ${ }^{185-188}$, however many hurdles still have to overcome. In general, IncRNA levels in the circulation are very low, making their accurate and reproducible measurement cumbersome. An option would be to focus on expression levels in peripheral blood cells, such as monocytes and platelets. RNA extraction of specific cell types can be analysed using RNA sequencing or microarray analysis. This approach has already been applied to CVD patients in a couple of studies ${ }^{126,189}$.

Some hurdles will need to be overcome before IncRNAs become feasible therapeutic targets. Currently, technical challenges lie in the use of tools to overexpress or knockdown IncRNAs and/or their targets. Preclinical studies show great potential for some IncRNAs, but poor conservation is still an issue. Gaining knowledge about how IncRNAs act, and in which cellular processes they are involved, will help to identify therapeutic candidates. Nevertheless, human-specific IncRNAs and IncRNAs that are conserved have potential for future treatments of human disease. The GENCODE Consortium executed a great deal of experiments to investigate their potential and to map IncRNAs expressed in humans ${ }^{99,190}$. With close to 10,000 IncRNAs estimated to be transcribed from the human genome, the majority of which remains to be investigated. With the goal of finding their biological role, and to uncover their therapeutic potential.

\section{Conclusion}

Although many IncRNAs have been identified (and annotated), the understanding of their biological roles is in its infancy. Nonetheless, emerging evidence indicates that several IncRNAs play a major role in the development and progression of CVD. Functional studies targeting IncRNA have been shown to affect cardiac function and outcome in preclinical models of fibrosis, cardiac hypertrophy, and sepsis. Future studies should focus on translating these findings to the human situation, and investigate their therapeutic potential for diagnosing or treating HF.

\section{Acknowledgments}

The authors thank Emma Louise Robinson for textual suggestions at various points in the manuscript, and Wouter Verhesen for his help with figure design. This work was supported by the Netherlands Organization for Scientific Research (NWO) (grants no. 917.14.363 VIDI to BS), the Netherlands Heart Foundation Dekker (grant no. 2014T105 to BS), Health Foundation Limburg (to BS), and an ERA-CVD Joint International Call grant (Netherlands Heart Foundation and NWO-ZonMw Grant no. 2016 T091 to MvB). 


\section{References}

1. Roth, G. A. et al. Global and regional patterns in cardiovascular mortality from 1990 to 2013. Circulation 132, 1667-1678 (2015).

2. Metra, M. \& Teerlink, J. R. Heart failure. Lancet 6736, (2017).

3. Tesauro, M. et al. Arterial ageing: from endothelial dysfunction to vascular calcification. J. Intern. Med. 281, 471-482 (2017).

4. Azevedo, P. S., Polegato, B. F., Minicucci, M. F., Paiva, S. A. R. \& Zornoff, L. A. M. Cardiac Remodeling: Concepts, Clinical Impact, Pathophysiological Mechanisms and Pharmacologic Treatment. Arq. Bras. Cardiol. 62-69 (2016). doi:10.5935/abc.20160005

5. Strait, J. B. \& Lakatta, E. G. Aging-Associated Cardiovascular Changes and Their Relationship to Heart Failure. Heart Fail. Clin. 8, 143-164 (2012).

6. Lozano, R. et al. Global and regional mortality from 235 causes of death for 20 age groups in 1990 and 2010: A systematic analysis for the Global Burden of Disease Study 2010. Lancet 380, 2095-2128 (2012).

7. Birney, E. et al. Identification and analysis of functional elements in $1 \%$ of the human genome by the ENCODE pilot project. Nature 447, 799-816 (2007).

8. Markopoulos, G. S. et al. A step-by-step microRNA guide to cancer development and metastasis. Cell. Oncol. 40, 303-339 (2017).

9. Behm-Ansmant, I., Rehwinkel, J. \& Izaurralde, E. MicroRNAs Silence Gene Expression by Repressing Protein Expression and / or by Promoting mRNA Decay. Cold Spring Harb Symp Quant Biol. 71, 523-530 (2006).

10. Çalışkan, M., Güler, H. \& Bozok Çetintaş, V. Current updates on microRNAs as regulators of chemoresistance. Biomed. Pharmacother. 95, 1000-1012 (2017).

11. Yu, N., Zhang, Q., Liu, Q., Yang, J. \& Zhang, S. A meta-analysis: <i>microRNAs'</i> prognostic function in patients with nonsmall cell lung cancer. Cancer Med. (2017). doi:10.1002/cam4.1158

12. Balacescu, O. et al. Urinary microRNAs for prostate cancer diagnosis, prognosis, and treatment response: are we there yet? Wiley Interdiscip. Rev. RNA e1438 (2017). doi:10.1002/wrna.1438

13. Hamam, R. et al. Circulating microRNAs in breast cancer: novel diagnostic and prognostic biomarkers. Cell Death Dis. 8, e3045 (2017).

14. Faravelli, I. \& Corti, S. MicroRNA-Directed Neuronal Reprogramming as a Therapeutic Strategy for Neurological Diseases. Mol. Neurobiol. 1-9 (2017). doi:10.1007/s12035-017-0671-7

15. Saraiva, C., Esteves, M. \& Bernardino, L. MicroRNA: Basic concepts and implications for regeneration and repair of neurodegenerative diseases. Biochem. Pharmacol. 141, 118-131 (2017).

16. Sun, T. et al. The Role of MicroRNAs in Myocardial Infarction: From Molecular Mechanism to Clinical Application. Int. J. Mol. Sci. 18, 745 (2017).

17. Laffont, B. \& Rayner, K. J. MicroRNAs in the Pathobiology and Therapy of Atherosclerosis. Can. J. Cardiol 33, 313-324 (2017).

18. Barwari, T., Joshi, A. \& Mayr, M. MicroRNAs in Cardiovascular Disease. J. Am. Coll. Cardiol. 68, 2577-2584 (2016).

19. Schulte, C., Karakas, M. \& Zeller, T. microRNAs in cardiovascular disease - clinical application. Clin. Chem. Lab. Med. 0, 1-21 (2016).

20. Verjans, R., van Bilsen, M. \& Schroen, B. MiRNA Deregulation in Cardiac Aging and Associated Disorders. International Review of Cell and Molecular Biology 334, (Elsevier Inc., 2017). 
21. Brown, C. J. et al. The human XIST gene: Analysis of a $17 \mathrm{~kb}$ inactive X-specific RNA that contains conserved repeats and is highly localized within the nucleus. Cell 71, 527-542 (1992).

22. Brockdorff, N. et al. The product of the mouse Xist gene is a $15 \mathrm{~kb}$ inactive X-pecific transcript containing no conserved ORF and located in the nucleus. Cell 71, 515-526 (1992).

23. Brannan, C. I., Dees, E. C., Ingram, R. S. \& Tilghman, S. M. The product of the H19 gene may function as an RNA. Mol Cell Biol 10, 28-36. (1990).

24. Korostowski, L., Sedlak, N. \& Engel, N. The Kcnq1ot1 Long Non-Coding RNA Affects Chromatin Conformation and Expression of Kcnq1, but Does Not Regulate Its Imprinting in the Developing Heart. PLoS Genet. 8, (2012).

25. Roeszler, K. N., Itman, C., Sinclair, A. H. \& Smith, C. A. The long non-coding RNA, MHM, plays a role in chicken embryonic development, including gonadogenesis. Dev. Biol. 366, 317-326 (2012).

26. Kapranov, P. et al. RNA Maps Reveal New RNA Classes and a Possible Function for Pervasive Transcription. Science (80-. ). 316, 1484-1488 (2007).

27. Amaral, P. P., Clark, M. B., Gascoigne, D. K., Dinger, M. E. \& Mattick, J. S. LncRNAdb: A reference database for long noncoding RNAs. Nucleic Acids Res. 39, 146-151 (2011).

28. Tiedge, H., Fremeau, R. T., Weinstock, P. H., Arancio, O. \& Brosius, J. Dendritic location of neural BC1 RNA. Proc. Natl. Acad. Sci. 88, 2093-2097 (1991).

29. Parrott, A. M. \& Mathews, M. B. Novel rapidly evolving hominid RNAs bind nuclear factor 90 and display tissue-restricted distribution. Nucleic Acids Res. 35, 6249-6258 (2007).

30. Ahanda, M. L. E. et al. Non-coding RNAs revealed during identification of genes involved in chicken immune responses. Immunogenetics 61, 55-70 (2009).

31. Erdmann, V. A., Szymanski, M., Hochberg, A., De Groot, N. \& Barciszewski, J. Collection of mRNA-like noncoding RNAs. Nucleic Acids Res. 27, 192-195 (1999).

32.

Dykes, I. M. \& Emanueli, C. Transcriptional and Post-transcriptional Gene Regulation by Long Non-coding RNA. Genomics. Proteomics Bioinformatics 15, 177-186 (2017).

33. Johnsson, P., Lipovich, L., Grandér, D. \& Morris, K. V. Evolutionary conservation of long non-coding RNAs; sequence, structure, function. Biochim. Biophys. Acta - Gen. Subj. 1840, 1063-1071 (2014).

34. Novikova, I. V., Hennelly, S. P. \& Sanbonmatsu, K. Y. Tackling structures of long noncoding RNAs. Int. J. Mol. Sci. 14, 23672-23684 (2013).

35. Yan, K. et al. Structure prediction: New insights into decrypting long noncoding RNAs. Int. J. Mol. Sci. 17, (2016).

36. Ma, L., Bajic, V. B. \& Zhang, Z. On the classification of long non-coding RNAs. RNA Biol. 10, 924-933 (2013).

37. Wang, K. C. \& Chang, H. Y. Molecular Mechanisms of Long Noncoding RNAs. Mol. Cell 43, 904-914 (2011).

38. Pandey, R. R. et al. Kcnq1ot1 Antisense Noncoding RNA Mediates Lineage-Specific Transcriptional Silencing through Chromatin-Level Regulation. Mol. Cell 32, 232-246 (2008).

39. Mohammad, F., Mondal, T. \& Kanduri, C. Epigenetics of imprinted long noncoding RNAs. Epigenetics 4, 277-286 (2009).

40. Azzalin, C. M., Reichenbach, P., Khoriauli, L., Giulotto, E. \& Lingner, J. Telomeric Repeat-Containing RNA and RNA Surveillance Factors at Mammalian Chromosome Ends. Science 318, 798-801 (2007).

41. Redon, S., Reichenbach, P. \& Lingner, J. The non-coding RNA TERRA is a natural ligand and direct inhibitor of human telomerase. Nucleic Acids Res. 38, 5797-5806 (2010). 
42. Tripathi, V. et al. The nuclear-retained noncoding RNA MALAT1 regulates alternative splicing by modulating SR splicing factor phosphorylation. Mol. Cell 39, 925-938 (2010).

43. Salmena, L., Poliseno, L., Tay, Y., Kats, L. \& Pandolfi, P. P. A ceRNA hypothesis: The rosetta stone of a hidden RNA language? Cell 146, 353-358 (2011).

44. Huang, Z.-W., Tian, L.-H., Yang, B. \& Guo, R.-M. Long Noncoding RNA H19 Acts as a Competing Endogenous RNA to Mediate CTGF Expression by Sponging miR-455 in Cardiac Fibrosis. DNA Cell Biol. 36, dna.2017.3799 (2017).

45. Liu, Y., Tao, Z., Qu, J., Zhou, X. \& Zhang, C. Long non-coding RNA PCAT7 regulates ELF2 signaling through inhibition of miR-134-5p in nasopharyngeal carcinoma. Biochem. Biophys. Res. Commun. 491, 374-381 (2017)

46. Lv, M. et al. IncRNA H19 regulates epithelial-mesenchymal transition and metastasis of bladder cancer by miR-29b-3p as competing endogenous RNA. Biochim. Biophys. Acta - Mol. Cell Res. 1864, 1887-1899 (2017).

47. Liu, T. et al. Curcumin suppresses proliferation and in vitro invasion of human prostate cancer stem cells by ceRNA effect of miR-145 and IncRNA-ROR. Gene 631, 29-38 (2017).

48. Fang, C. et al. Long non-coding RNA HNF1A-AS1 mediated repression of miR-34a/SIRT1/p53 feedback loop promotes the metastatic progression of colon cancer by functioning as a competing endogenous RNA. Cancer Lett. 410, 50-62 (2017).

49. Guttman, M. et al. LincRNAs act in the circuitry controlling pluripotency and differentiation. Nature 477, 295300 (2011).

50. Tsai, M. et al. Long Noncoding RNA as Modular Scaffold of Histone Modification Complexes. Science (80-. ). 329, 689-693 (2010).

51. Long, Y., Wang, X., Youmans, D. T. \& Cech, T. R. How do IncRNAs regulate transcription? Sci. Adv. 3, eaao2110 (2017).

52. Li, W. et al. Functional roles of enhancer RNAs for oestrogen-dependent transcriptional activation. Nature 498, 516-520 (2013).

53. Lasda, E., Parker, R. \& Parker, R. O. Y. Circular RNAs: diversity of form and function Circular RNAs: diversity of form and function. Rna 1829-1842 (2014). doi:10.1261/rna.047126.114.DIFFERENT

54. Greene, J. et al. Circular RNAs: Biogenesis, Function and Role in Human Diseases. Front. Mol. Biosci. 4, 111 (2017).

55. Burd, C. E. et al. Expression of linear and novel circular forms of an INK4/ARF-associated non-coding RNA correlates with atherosclerosis risk. PLoS Genet. 6, 1-15 (2010).

56. Shukla, C. J. et al. High-throughput identification of RNA nuclear enrichment sequences. EMBO J. e98452 (2018). doi:10.15252/embj.201798452

57. Kashi, K., Henderson, L., Bonetti, A. \& Carninci, P. Discovery and functional analysis of IncRNAs: Methodologies to investigate an uncharacterized transcriptome. Biochim. Biophys. Acta - Gene Regul. Mech. 1859, 3-15 (2016).

58. Ziaeian, B. \& Fonarow, G. C. Epidemiology and aetiology of heart failure. Nat. Rev. Cardiol. 13, 1-11 (2016).

59. Bui, Anh, L., Horwish, Tamara, B. \& Fonarow, Gregg, C. Epidemiology and risk profile of heart failure. Nat. Publ. Gr. 8, 1-25 (2012).

60. Heineke, J. \& Molkentin, J. D. Regulation of cardiac hypertrophy by intracellular signalling pathways. Nat. Rev. Mol. Cell Biol. 7, 589-600 (2006).

61. Liu, R. \& Molkentin, J. D. Regulation of cardiac hypertrophy and remodeling through the dual-specificity MAPK phosphatases (DUSPs). J. Mol. Cell. Cardiol. 101, 44-49 (2016). 
62. Aoyagi, T. \& Matsui, T. Phosphoinositide-3 kinase signaling in cardiac hypertrophy and heart failure. Curr. Pharm. Des. 17, 1818-24 (2011).

63. Clerk, A. et al. Regulation of Mitogen-Activated Protein Kinases in Cardiac Myocytes through the Small G Protein Rac1 Regulation of Mitogen-Activated Protein Kinases in Cardiac Myocytes through the Small G Protein Rac1. 21, 1173-1184 (2001).

64. Dorn 2nd, G. W., Force, T. \& li, G. W. D. Protein kinase cascades in the regulation of cardiac hypertrophy. $J$ Clin Invest 115, 527-537 (2005).

65. Akazawa, H. \& Komuro, I. Roles of cardiac transcription factors in cardiac hypertrophy. Circ. Res. 92, 10791088 (2003).

66. Han, P. et al. A long noncoding RNA protects the heart from pathological hypertrophy. Nature 514, 102-6 (2014).

67. Xuan, L. et al. Circulating long non-coding RNAs NRON and MHRT as novel predictive biomarkers of heart failure. J. Cell. Mol. Med. 21, 1803-1814 (2017).

68. Viereck, J. et al. Long noncoding RNA Chast promotes cardiac remodeling. Sci. Transl. Med. 8, 326ra22$326 r a 22$ (2016).

69. Wang, Z. et al. The long noncoding RNA Chaer defines an epigenetic checkpoint in cardiac hypertrophy. Nat. Med. 22, 1131-1139 (2016).

70. McEwan, D. G. et al. PLEKHM1 regulates autophagosome-lysosome fusion through HOPS complex and LC3/GABARAP proteins. Mol. Cell 57, 39-54 (2015).

71. Shao, M., Chen, G., Lv, F., Liu, Y. \& Tian, H. LncRNA TINCR attenuates cardiac hypertrophy by epigenetically silencing of CaMKII. Oncotarget 8, 47565-47473 (2017).

72. Yoo, K. H. \& Hennighausen, L. EZH2 methyltransferase and H3K27 methylation in breast cancer. Int. J. Biol. Sci. 8, 59-65 (2011).

73. $\mathrm{Xu}, \mathrm{T}$. P. et al. SP1-induced upregulation of the long noncoding RNA TINCR regulates cell proliferation and apoptosis by affecting KLF2 mRNA stability in gastric cancer. Oncogene 34, 5648-5661 (2015).

74. Hutchinson, J. N. et al. A screen for nuclear transcripts identifies two linked noncoding RNAs associated with SC35 splicing domains. BMC Genomics 8, 39 (2007).

75. Michalik, K. M. et al. Long noncoding RNA MALAT1 regulates endothelial cell function and vessel growth. Circ. Res. 114, 1389-1397 (2014).

76. Zhang, B. et al. The IncRNA Malat1 is dispensable for mouse development but its transcription plays a cisregulatory role in the adult. Cell Rep. 2, 111-123 (2012).

77. Eißmann, M. et al. Loss of the abundant nuclear non-coding RNA MALAT1 is compatible with life and development. RNA Biol. 9, 1076-87 (2012).

78. Nakagawa, S. et al. Malat1 is not an essential component of nuclear speckles in mice. RNA 18, 1487-1499 (2012).

79. Peters, T. et al. Long non-coding RNA malat-1 is dispensable during pressure overload-induced cardiac remodeling and failure in mice. PLoS One 11, (2016).

80. Cowley, D. et al. Registered report: A coding-independent function of gene and pseudogene mRNAs regulates tumour biology. Elife 4, 1033-1038 (2015).

81. Wang, K. et al. The long noncoding RNA CHRF regulates cardiac hypertrophy by targeting miR-489. Circ. Res. 114, 1377-1388 (2014).

82. $\mathrm{Li}, \mathrm{T}$. et al. MyD88-dependent nuclear factor-kappaB activation is involved in fibrinogen-induced hypertrophic response of cardiomyocytes. J. Hypertens. 27, 1084-1093 (2009). 
83. Zhu, X.-H., Yuan, Y.-X., Rao, S.-L. \& Wang, P. LncRNA MIAT enhances cardiac hypertrophy partly through sponging miR-150. Eur. Rev. Med. Pharmacol. Sci. 20, 3653-60 (2016).

84. Liu, L. et al. The H19 long noncoding RNA is a novel negative regulator of cardiomyocyte hypertrophy. Cardiovasc. Res. 111, 56-65 (2016).

85. Kreusser, M. M. \& Backs, J. Integrated mechanisms of CaMKII-dependent ventricular remodeling. Front. Pharmacol. 5 MAR, 1-8 (2014).

86. Backs, J., Song, K., Bezprozvannaya, S., Chang, S. \& Olson, E. N. CaM kinase II selectively signals to histone deacetylase 4 during cardiomyocyte hypertrophy. J. Clin. Invest. 116, 1853-1864 (2006).

87. Backs, J. \& Olson, E. N. Control of cardiac growth by histone acetylation/deacetylation. Circ. Res. 98, 15-24 (2006).

88. Jiang, F., Zhou, X. \& Huang, J. Long Non-Coding RNA-ROR Mediates the Reprogramming in Cardiac Hypertrophy. PLoS One 11, e0152767 (2016).

89. Liu, Y., Liang, Y., Zhang, J. fang \& Fu, W. ming. MicroRNA-133 mediates cardiac diseases: Mechanisms and clinical implications. Exp. Cell Res. 354, 65-70 (2017).

90. Han, X., Yang, F., Cao, H. \& Liang, Z. Malat1 regulates serum response factor through miR-133 as a competing endogenous RNA in myogenesis. FASEB J. 29, 3054-3064 (2015).

91. Lai, Y. et al. HOTAIR functions as a competing endogenous RNA to regulate PTEN expression by inhibiting miR-19 in cardiac hypertrophy. Mol. Cell. Biochem. 0, 1-9 (2017).

92. Matkovich, S. J., Edwards, J. R., Grossenheider, T. C., de Guzman Strong, C. \& Dorn, G. W. 2nd. Epigenetic coordination of embryonic heart transcription by dynamically regulated long noncoding RNAs. Proc. Natl. Acad. Sci. U. S. A. 111, 12264-12269 (2014).

93. Song, C. et al. Construction and analysis of cardiac hypertrophy-associated IncRNA-mRNA network based on competitive endogenous RNA reveal functional IncRNAs in cardiac hypertrophy. Oncotarget 7, 1082710840 (2016).

94. Li, D. et al. Transcriptome analysis reveals distinct patterns of long noncoding RNAs in heart and plasma of mice with heart failure. PLoS One 8, e77938 (2013).

95. Sun, L. et al. Expression profile of long non-coding RNAs in a mouse model of cardiac hypertrophy. Int. J. Cardiol. 177, 73-75 (2014).

96. Lee, J. H. et al. Analysis of transcriptome complexity through RNA sequencing in normal and failing murine hearts. Circ. Res. 109, 1332-1341 (2011).

97. Ounzain, S. et al. CARMEN, a human super enhancer-associated long noncoding RNA controlling cardiac specification, differentiation and homeostasis. J. Mol. Cell. Cardiol. 89, 98-112 (2015).

98. Li, X., Zhang, L. \& Liang, J. Unraveling the Expression Profiles of Long Noncoding RNAs in Rat Cardiac Hypertrophy and Functions of IncRNA BC088254 in Cardiac Hypertrophy Induced by Transverse Aortic Constriction. Cardiol. 134, 84-98 (2016).

99. Derrien, T. et al. The GENCODE v7 catalog of human long noncoding RNAs: Analysis of their gene structure, evolution, and expression. Genome Res. 22, 1775-1789 (2012).

100. Larcher, V. et al. An autofluorescence-based method for the isolation of highly purified ventricular cardiomyocytes. Cardiovasc. Res. 1-8 (2017). doi:10.1093/cvr/cvx239

101. Müller, P. et al. Intramyocardial fate and effect of iron nanoparticles co-injected with MACS $®$ purified stem cell products. Biomaterials 135, 74-84 (2017).

102. Thienpont, B. et al. The H3K9 dimethyltransferases EHMT1/2 protect against pathological cardiac hypertrophy. J. Clin. Invest. 127, 335-348 (2017). 
103. Wang, K. et al. CARL IncRNA inhibits anoxia-induced mitochondrial fission and apoptosis in cardiomyocytes by impairing miR-539-dependent PHB2 downregulation. Nat. Commun. 5, 3596 (2014).

104. Klattenhoff, C. A. et al. Braveheart, a long noncoding RNA required for cardiovascular lineage commitment. Cell 152, 570-583 (2013).

105. Travers, J. G., Kamal, F. A., Robbins, J., Yutzey, K. E. \& Blaxall, B. C. Cardiac fibrosis: The fibroblast awakens. Circ. Res. 118, 1021-1040 (2016).

106. Fan, D., Takawale, A., Lee, J. \& Kassiri, Z. Cardiac fibroblasts, fibrosis and extracellular matrix remodeling in heart disease. Fibrogenesis Tissue Repair 5, 15 (2012).

107. Xia, Y. et al. Characterization of the inflammatory and fibrotic response in a mouse model of cardiac pressure overload. Histochem. Cell Biol. 131, 471-481 (2009).

108. Rai, V., Sharma, P., Agrawal, S. \& Agrawal, D. K. Relevance of mouse models of cardiac fibrosis and hypertrophy in cardiac research. Mol. Cell. Biochem. 424, 123-145 (2017).

109. Edgley, A. J., Krum, H. \& Kelly, D. J. Targeting fibrosis for the treatment of heart failure: A role for transforming growth factor- $\beta$. Cardiovasc. Ther. 30, 30-40 (2012).

110. Chaudhury, A. \& Howe, P. H. The tale of transforming growth factor-beta (TGF $\beta$ ) signaling: A soigné enigma. IUBMB Life 61, 929-939 (2009).

111. Jiang, X. Y. \& Ning, Q. L. Expression profiling of long noncoding RNAs and the dynamic changes of IncRNANR024118 and Cdkn1c in angiotensin II-treated cardiac fibroblasts. Int. J. Clin. Exp. Pathol. 7, 1325-1336 (2014).

112. Jiang, X., Zhang, F. \& Ning, Q. Losartan reverses the down-expression of long noncoding RNA-NR024118 and Cdkn1c induced by angiotensin II in adult rat cardiac fibroblasts. Pathol. Biol. 63, 122-125 (2015).

113. Tao, $\mathrm{H}$. et al. Long noncoding RNA H19 controls DUSP5/ERK1/2 axis in cardiac fibroblast proliferation and fibrosis. Cardiovasc. Pathol. 25, 381-389 (2016).

114. Ounzain, S. et al. Genome-wide profiling of the cardiac transcriptome after myocardial infarction identifies novel heart-specific long non-coding RNAs. Eur. Heart J. 36, 353-368 (2015).

115. Qu, X. et al. MIAT Is a Pro-fibrotic Long Non-coding RNA Governing Cardiac Fibrosis in Post-infarct Myocardium. Sci. Rep. 7, 42657 (2017).

116. Piccoli, M. T. et al. Inhibition of the cardiac fibroblast-enriched IncRNA Meg3 prevents cardiac fibrosis and diastolic dysfunction. Circ. Res. 121, 575-583 (2017).

117. Mondal, T. et al. MEG3 long noncoding RNA regulates the TGF- $\beta$ pathway genes through formation of RNADNA triplex structures. Nat. Commun. 6, (2015).

118. Terashima, M., Tange, S., Ishimura, A. \& Suzuki, T. MEG3 long noncoding RNA contributes to the epigenetic regulation of epithelial-mesenchymal transition in lung cancer cell lines. J. Biol. Chem. 292, 8299 (2017).

119. Micheletti, R. et al. The long noncoding RNA Wisper controls cardiac fibrosis and remodeling. Sci. Transl. Med. 8, 336ra22 (2016).

120. Zangrando, J. et al. Identification of candidate long non-coding RNAs in response to myocardial infarction. BMC Genomics 15, 460 (2014).

121. Tu, G. et al. Long noncoding NONRATT021972 siRNA normalized abnormal sympathetic activity mediated by the upregulation of $\mathrm{P} 2 \mathrm{X} 7$ receptor in superior cervical ganglia after myocardial ischemia. Purinergic Signal. 12, 521-535 (2016).

122. Zou, L. et al. LncRNA NONRATT021972 involved the pathophysiologic processes mediated by P2X7receptors in stellate ganglia after myocardial ischemic injury. Purinergic Signal. 12, 127-137 (2016). 
123. Zhang, J., Gao, C., Meng, M. \& Tang, H. Long Noncoding RNA MHRT Protects Cardiomyocytes against H 2 O 2 -Induced Apoptosis. 24, 19-24 (2016).

124. Qu, X. et al. Expression signature of IncRNAs and their potential roles in cardiac fibrosis of post-infarct mice. Int. J. Cardiol. 0, 1-11 (2016).

125. Saddic, L. A. et al. The Long Noncoding RNA Landscape of the Ischemic Human Left Ventricle. Circ. Cardiovasc. Genet. 10, e001534 (2017).

126. Vausort, M., Wagner, D. R. \& Devaux, Y. Long noncoding RNAs in patients with acute myocardial infarction. Circ. Res. 115, 668-677 (2014).

127. Gao, L. et al. Circulating Long Noncoding RNA HOTAIR is an Essential Mediator of Acute Myocardial Infarction. Cell. Physiol. Biochem. 44, 1497-1508 (2017).

128. Liu, Y. et al. Expression profiling and ontology analysis of long noncoding RNAs in post-ischemic heart and their implied roles in ischemia/reperfusion injury. Gene 543, 15-21 (2014).

129. Li, H. et al. The role of a Novel Long Non-Coding RNA TUC40- in Cardiomyocyte Induction and Maturation in P19 Cells. Am. J. Med. Sci. 354, 608-616 (2017).

130. Zhao, R. et al. Inhibition of long noncoding RNA BDNF-AS rescues cell death and apoptosis in hypoxia/reoxygenation damaged murine cardiomyocyte. Biochimie 138, 43-49 (2017).

131. Li, H. qi et al. Obestatin attenuated doxorubicin-induced cardiomyopathy via enhancing long noncoding Mhrt RNA expression. Biomed. Pharmacother. 81, 474-481 (2016).

132. Long, B. et al. Long noncoding RNA FTX regulates cardiomyocyte apoptosis by targeting miR-29b-1-5p and Bcl2I2. Biochem. Biophys. Res. Commun. 495, 312-318 (2018).

133. Wu, T. et al. Knockdown of Long Non-Coding RNA-ZFAS1 Protects Cardiomyocytes Against Acute Myocardial Infarction Via Anti-Apoptosis by Regulating miR-150/CRP. J. Cell. Biochem. 118, 3281-3289 (2017).

134. Nikoletopoulou, V., Markaki, M., Palikaras, K. \& Tavernarakis, N. Crosstalk between apoptosis, necrosis and autophagy. Biochim. Biophys. Acta - Mol. Cell Res. 1833, 3448-3459 (2013).

135. Nishida, K., Kyoi, S., Yamaguchi, O., Sadoshima, J. \& Otsu, K. The role of autophagy in the heart. Cell Death Differ. 16, 31-38 (2009).

136. Hamacher-Brady, A., Brady, N. R. \& Gottlieb, R. A. Enhancing macroautophagy protects against ischemia/reperfusion injury in cardiac myocytes. J. Biol. Chem. 281, 29776-29787 (2006).

137. Wesselborg, S. \& Stork, B. Autophagy signal transduction by ATG proteins: From hierarchies to networks. Cell. Mol. Life Sci. 72, 4721-4757 (2015).

138. Wang, K. et al. APF IncRNA regulates autophagy and myocardial infarction by targeting miR-188-3p. Nat. Commun. 6, 6779 (2015).

139. Greco, S. et al. Increased BACE1-AS long noncoding RNA and $\beta$-amyloid levels in heart failure. Cardiovasc. Res. 113, 453-463 (2017).

140. $\mathrm{Li}$, X. et al. Down-regulation of IncRNA KCNQ1OT1 protects against myocardial ischemia/reperfusion injury following acute myocardial infarction. Biochem. Biophys. Res. Commun. 491, 1026-1033 (2017).

141. Liu, Y. et al. Long non coding RNA-UCA1 contributes to cardiomyocyte apoptosis by suppression of p27 expression. Cell. Physiol. Biochem. 35, 1986-1998 (2015).

142. Wang, K. et al. The long noncoding RNA NRF regulates programmed necrosis and myocardial injury during ischemia and reperfusion by targeting miR-873. Cell Death Differ. 23, 1394-1405 (2016).

143. Marchant, D. J. et al. Inflammation in myocardial diseases. Circ. Res. 110, 126-144 (2012).

144. Vieillard-Baron, A. Septic cardiomyopathy. Ann. Intensive Care 1, 6 (2011). 
145. Wu, H., Liu, J., Li, W., Liu, G. \& Li, Z. LncRNA-HOTAIR promotes TNF-a production in cardiomyocytes of LPS-induced sepsis mice by activating NF-KB pathway. Biochem. Biophys. Res. Commun. 471, 240-246 (2016).

146. Zhuang, Y. T. et al. IL-6 induced IncRNA MALAT1 enhances TNF-alpha expression in LPS-induced septic cardiomyocytes via activation of SAA3. Eur Rev Med Pharmacol Sci 21, 302-309 (2017).

147. Li, X., Zhou, J. \& Huang, K. Inhibition of the IncRNA Mirt1 Attenuates Acute Myocardial Infarction by Suppressing NF-kB Activation. Cell. Physiol. Biochem. 42, 2144-2144 (2017).

148. Spurlock, C. F. et al. Expression and functions of long noncoding RNAs during human $T$ helper cell differentiation. Nat. Commun. 6, 1-12 (2015).

149. Casero, D. et al. Long non-coding RNA profiling of human lymphoid progenitor cells reveals transcriptional divergence of B cell and T cell lineages. Nat. Immunol. 16, 1282-1291 (2015).

150. Gu, G. et al. Differential expression of long noncoding RNAs during cardiac allograft rejection. Transplantation 101, 83-91 (2017).

151. Schroen, B. \& Heymans, S. Small but smartmicroRNAs in the centre of inflammatory processes during cardiovascular diseases, the metabolic syndrome, and ageing. Cardiovasc. Res. 93, 605-613 (2012).

152. Frade, A. F. et al. Myocardial Infarction-Associated Transcript, a Long Noncoding RNA, Is Overexpressed during Dilated Cardiomyopathy Due to Chronic Chagas Disease. J. Infect. Dis. 214, 161-165 (2016).

153. Intengan, H. D. \& Schiffrin, E. L. Vascular Remodeling in Hypertension. Hypertension 38, 581-587 (2001).

154. Renna, N. F., De Las Heras, N. \& Miatello, R. M. Pathophysiology of vascular remodeling in hypertension. Int. J. Hypertens. 2013, (2013).

155. Fiedler, J. et al. Development of long noncoding RNA-based strategies to modulate tissue vascularization. J. Am. Coll. Cardiol. 66, 2005-2015 (2015).

156. Leisegang, M. S. et al. Long Noncoding RNA MANTIS Facilitates Endothelial Angiogenic Function. Circulation CIRCULATIONAHA.116.026991 (2017). doi:10.1161/CIRCULATIONAHA.116.026991

157. Brock, M. et al. Analysis of hypoxia-induced noncoding RNAs reveals metastasis-associated lung adenocarcinoma transcript 1 as an important regulator of vascular smooth muscle cell proliferation. Exp. Biol. Med. 153537021668543 (2017). doi:10.1177/1535370216685434

158. Leung, A. et al. Novel long noncoding RNAs are regulated by angiotensin II in vascular smooth muscle cells. Circ. Res. 113, 266-278 (2013).

159. Zhu, N. et al. Endothelial enriched microRNAs regulate angiotensin II-induced endothelial inflammation and migration. Atherosclerosis 215, 286-293 (2011).

160. Liu, X. et al. A Necessary role of miR-221 and miR-222 in vascular smooth muscle cell proliferation and neointimal hyperplasia. Circ. Res. 104, 476-486 (2009).

161. Bischoff, F. C. et al. Identification and Functional Characterization of Hypoxia-Induced Endoplasmic Reticulum Stress Regulating IncRNA (HypERInc) in Pericytes. Circ. Res. 121, 368-375 (2017).

162. Lakatta, E. G. \& Levy, D. Arterial and Cardiac Aging: Major Shareholders in Cardiovascular Disease Enterprises Part I: Aging Arteries : A “Set Up” for Vascular Disease. Circulation 107, 139-146 (2003).

163. Lakatta, E. G. Arterial and Cardiac aging: Major Shareholders in Cardiovascular Disease Enterprises Part III: Cellular and Molecular Clues to Heart and Arterial Aging. Circulation 107, 490-497 (2003).

164. Lakatta, E. G. \& Levy, D. Arterial and Cardiac Aging: Major Shareholders in Cardiovascular Disease Enterprises Part II : The Aging Heart in Health : Links to Heart Disease. Circulation 107, 346-354 (2003).

165. Costantino, S., Paneni, F. \& Cosentino, F. Ageing, metabolism and cardiovascular disease. J. Physiol. 594, 2061-2073 (2016). 
166. Sinclair, D., North, B., Editors, G., North, B. J. \& Sinclair, D. A. The Intersection Between Aging and Cardiovascular Disease. 02115, 1097-1108 (2012).

167. Childs, B. G., Durik, M., Baker, D. J. \& van Deursen, J. M. Cellular senescence in aging and age-related disease: from mechanisms to therapy. Nat. Med. 21, 1424-1435 (2015).

168. Siddiqi, S. \& Sussman, M. A. Cardiac Hegemony of Senescence. Curr. Transl. Geriatr. Exp. Gerontol. Rep. 2, 247-254 (2013).

169. Sharifi-Sanjani, M. et al. Cardiomyocyte-Specific Telomere Shortening is a Distinct Signature of Heart Failure in Humans. J. Am. Heart Assoc. 6, e005086 (2017).

170. Maicher, A., Kastner, L., Dees, M. \& Luke, B. Deregulated telomere transcription causes replicationdependent telomere shortening and promotes cellular senescence. Nucleic Acids Res. 40, 6649-6659 (2012).

171. Yu, T.-Y., Kao, Y. \& Lin, J.-J. Telomeric transcripts stimulate telomere recombination to suppress senescence in cells lacking telomerase. Proc. Natl. Acad. Sci. 111, 3377-3382 (2014).

172. Abdelmohsen, K. et al. Senescence-associated IncRNAs: Senescence-associated long noncoding RNAs Aging Cell 12, 890-900 (2013).

173. Tripathi, V. et al. Long Noncoding RNA MALAT1 Controls Cell Cycle Progression by Regulating the Expression of Oncogenic Transcription Factor B-MYB. PLoS Genet. 9, (2013).

174. Wang, $X$. et al. Silencing of long noncoding RNA MALAT1 by miR-101 and miR-217 inhibits proliferation, migration, and invasion of esophageal squamous cell carcinoma cells. J. Biol. Chem. 290, 3925-3935 (2015).

175. Pocock, S. J. et al. Predicting survival in heart failure: A risk score based on 39372 patients from 30 studies. Eur. Heart J. 34, 1404-1413 (2013).

176. Watts, J. K. \& Corey, D. R. Silencing disease genes in the laboratory and the clinic. J. Pathol. 226, 365-379 (2012).

177. Wahlestedt, C. et al. Potent and nontoxic antisense oligonucleotides containing locked nucleic acids. Proc. Natl. Acad. Sci. 97, 5633-5638 (2000).

178. Kurreck, J. Design of antisense oligonucleotides stabilized by locked nucleic acids. Nucleic Acids Res. $\mathbf{3 0}$ 1911-1918 (2002).

179. Hagedorn, P. H., Hansen, B. R., Koch, T. \& Lindow, M. Managing the sequence-specificity of antisense oligonucleotides in drug discovery. Nucleic Acids Res. 45, 2262-2282 (2017).

180. Siomi, H. \& Siomi, M. C. On the road to reading the RNA-interference code. Nature 457, 396-404 (2009).

181. Zhang, X. et al. UCA1 Regulates the Growth and Metastasis of Pancreatic Cancer By Sponging MiR-135a. Oncol. Res. Featur. Preclin. Clin. Cancer Ther. 25, 1529-1541 (2017).

182. Lu, Y. et al. MYC targeted long non-coding RNA DANCR promotes cancer in part by reducing p21 levels. Cancer Res. 78, canres.0815.2017 (2017).

183. Leucci, E. et al. Melanoma addiction to the long non-coding RNA SAMMSON. Nature 531, 518-522 (2016).

184. Lin, A. et al. The LINK-A IncRNA activates normoxic HIF1a signalling in triple-negative breast cancer. Nat. Cell Biol. 18, 213-224 (2016).

185. Qiu, L., Tang, Q., Li, G. \& Chen, K. Long non-coding RNAs as biomarkers and therapeutic targets: Recent insights into hepatocellular carcinoma. Life Sci. 191, 273-282 (2017).

186. Roopesh S. Gangwar, Sanjay Rajagopalan, Rama Natarajan, and J. A. D. Non-coding RNAs in cardiovascular disease: pathological relevance and emerging role as biomarkers and therapeutics. Am. J. Hypertens. (2017). doi:10.1093/ajh/hpx197/4654930 
187. Wang, C. et al. Screening and identification of IncRNAs as potential biomarkers for pulmonary tuberculosis. Tuberculosis 108, 26-34 (2018).

188. Greco, S., Salgado-Somoza, A., Devaux, Y. \& Martelli, F. Long noncoding RNAs and cardiac disease. Antioxid. Redox Signal. 00, 7126 (2017).

189. Greco, S. et al. Long noncoding RNA dysregulation in ischemic heart failure. J. Transl. Med. 14, 183 (2016).

190. Harrow, J. et al. GENCODE: The Reference Human Genome Annotation for The ENCODE Project. Genome Res 22, 1760-1774 (2012). 




\section{Chapter 3}

\section{Long non-coding RNA Malat1 is dispensable during pressure overload-induced cardiac remodeling and failure in mice.}

Peters $\mathrm{T}^{1}$, Hermans-Beijnsberger $\mathbf{S}^{1}$, Beqqali $\mathrm{A}^{2}$, Bitsch $\mathrm{N}^{1}$, Nakagawa $\mathrm{S}^{3}$, Prasanth $\mathrm{KV}^{4}$, de Windt $\mathrm{LJ}^{1}$, van Oort RJ ${ }^{2}$, Heymans $\mathrm{S}^{1,5,6}$, Schroen $\mathrm{B}^{1}$

1 Department of Cardiology, CARIM School for Cardiovascular Diseases, Maastricht University, Universiteitssingel 50, 6200 MD Maastricht, the Netherlands.

2 Department of Experimental Cardiology, Academic Medical Center, Amsterdam, The Netherlands.

3 RNA Biology Laboratory, RIKEN, Wako, Saitama, Japan.

4 Department of Cell and Developmental Biology, University of Illinois at Urbana-Champaign, Urbana, IL, United States of America.

5 Netherlands Heart Institute (ICIN), Utrecht, The Netherlands.

6 Centre for Molecular and Vascular Biology (CMVB), Department of Cardiovascular Sciences, Katholieke Universiteit Leuven, Leuven, Belgium.

PLoS One. 2016 Feb 26;11(2):e0150236.

doi: 10.1371/journal.pone.0150236 



\begin{abstract}
Background

Long non-coding RNAs (IncRNAs) are a class of RNA molecules with diverse regulatory functions during embryonic development, normal life, and disease in higher organisms. However, research on the role of IncRNAs in cardiovascular diseases and in particular heart failure is still in its infancy. The exceptionally well conserved nuclear IncRNA Metastasis associated in lung adenocarcinoma transcript 1 (Malat1) is a regulator of mRNA splicing and highly expressed in the heart. Malat1 modulates hypoxia-induced vessel growth, activates ERK/MAPK signaling, and scavenges the anti-hypertrophic microRNA-133. We therefore hypothesized that Malat1 may act as regulator of cardiac hypertrophy and failure during cardiac pressure overload induced by thoracic aortic constriction (TAC) in mice.
\end{abstract}

\title{
Results
}

Absence of Malat1 did not affect cardiac hypertrophy upon pressure overload: Heart weight to tibia length ratio significantly increased in WT mice (sham: $5.78 \pm 0.55$, TAC $9.79 \pm 1.82$ $\mathrm{g} / \mathrm{mm} ; \mathrm{p}<0.001$ ) but to a similar extend also in Malat1 knockout (KO) mice (sham: $6.21 \pm 1.12$, TAC $8.91 \pm 1.74 \mathrm{~g} / \mathrm{mm} ; \mathrm{p}<0.01$ ) with no significant difference between genotypes. As expected, TAC significantly reduced left ventricular fractional shortening in WT (sham: $38.81 \pm 6.53 \%$, TAC: $23.14 \pm 11.99 \%$; $p<0.01$ ) but to a comparable degree also in KO mice (sham: $37.01 \pm 4.19 \%$, TAC: $25.98 \pm 9.75 \%$; $p<0.05$ ). Histological hallmarks of myocardial remodeling, such as cardiomyocyte hypertrophy, increased interstitial fibrosis, reduced capillary density, and immune cell infiltration, did not differ significantly between WT and KO mice after TAC. In line, the absence of Malat1 did not significantly affect angiotensin IIinduced cardiac hypertrophy, dysfunction, and overall remodeling. Above that, pressure overload by TAC significantly induced mRNA levels of the hypertrophy marker genes Nppa, $N p p b$ and Acta1, to a similar extend in both genotypes. Alternative splicing of Ndrg2 after TAC was apparent in WT (isoform ratio; sham: $2.97 \pm 0.26$, TAC 1.57 $\pm 0.40 ; p<0.0001$ ) and KO mice (sham: $3.64 \pm 0.37$; TAC: $2.24 \pm 0.76$; $p<0.0001$ ) and interestingly differed between genotypes both at baseline and after pressure overload ( $p<0.05$ each).

\section{Conclusion}

These findings confirm a role for the IncRNA Malat1 in mRNA splicing. However, no critical role for Malat1 was found in pressure overload-induced heart failure in mice, despite its reported role in vascularization, ERK/MAPK signaling, and regulation of miR-133. 


\section{Introduction}

The complexity of an organism is not related to the size of its genome nor to the number of proteins encoded therein but rather correlates with the number of genes that produce noncoding RNA ${ }^{1,2}$. Long non-coding RNAs (LncRNAs) were discovered in the early 1990's 3,4 and are nowadays defined as RNA molecules of $>200$ nucleotides in length, lacking a significant open reading frame. They are able to bind other RNA or DNA species as well as proteins and may thereby regulate processes at all stages from gene transcription and translation to protein function. The functions of many IncRNAs in transcriptional regulation have recently attracted much attention in the field of developmental biology (reviewed in ${ }^{5}$ ) and cancer research (reviewed in ${ }^{6}$ ). However, also cardiovascular research is beginning to recognize the importance of IncRNAs for heart development (e.g. SRA1) and pathology (e.g. MIAT) as recently reviewed ${ }^{7,8}$. The IncRNA Metastasis-associated adenocarcinoma transcript 1 (Malat1; also known as Nuclear Enriched Abundant Transcript 2, Neat2) was discovered in metastasizing non-small cell lung cancer ${ }^{9}$ and is highly expressed in most cell types and organs, including the heart. Increased expression of Malat1 is by now recognized as an established feature of many tumors and indicates poor prognosis ${ }^{10,11}$. Malat1 can bind to active chromatin sites ${ }^{12}$ and co-localizes with nuclear speckles, where it regulates pre-mRNA splicing ${ }^{13,14}$. Above that, a cis-regulatory role has been assigned to the Malat1 locus ${ }^{15}$. Given the high conservation and expression level of Malat1, several research groups simultaneously undertook the effort to generate Malat1 knockout mice. Surprisingly but consistently, none of the strains lacking Malat1 showed any obvious abnormalities during embryonic or post-natal development ${ }^{15-17}$, indicating that Malat1 is either completely dispensable or becomes important only under pathological conditions.

Heart failure (HF) is a condition in which the heart is unable to sustain sufficient blood flow through the body and is the fatal end stage of many heart diseases. About 23 million people worldwide suffer from $\mathrm{HF}$, with the highest prevalence in the growing elderly population ${ }^{18}$. A common cause for HF is cardiac pressure overload, which can be a consequence of hypertension or aortic valve stenosis. Pressure overload of the left ventricle (LV) causes a transient increase in vascularization that is necessary for adaptive cardiomyocyte growth and myocardial vessel density correlates with cardiac function ${ }^{19-21}$. Importantly, genetic ablation of Malat1 has recently been shown to reduce revascularization capacity after hind limb ischemia ${ }^{22}$. Above that, two groups have shown impaired myogenic differentiation after silencing of Malat1 in vitro ${ }^{23,24}$, possibly via regulation of microRNA-133. This microRNA has central roles in cardiac contractility and hypertrophy by repressing $\beta_{1}$-adrenergic receptor and serum response factor (SRF), respectively ${ }^{25,26}$. Scavenging of microRNA-133 by Malat1 may therefore increase levels of SRF, an important mediator of cardiac hypertrophy ${ }^{27}$. Similarly, ERK/MAPK signaling propagates pro-hypertrophic signaling in the heart ${ }^{28}$ and Malat1 was found to activate this pathway ${ }^{29}$. These reports strongly suggest a role for Malat1 in the development of cardiac hypertrophy and failure. Therefore, we subjected Malat1 knockout mice to either thoracic aortic constriction (TAC) or chronic infusion of angiotensin II (Angll) to induce pressure overload of the LV, mimicking aortic valve stenosis or systemic hypertension, respectively. Surprisingly, detailed analysis of cardiac morphology, function, and histology did not reveal an implication of Malat1 in myocardial hypertrophy, angiogenesis, inflammation, fibrosis, or dysfunction upon chronic cardiac pressure overload. 


\section{Methods}

\section{Mouse models}

Heterozygous Malat $1^{+/-}$mice derived from CBA $\times$C57BI/6 chimeric animals were provided by Shinichi Nakagawa after 6 backcrosses into C57BI/6N mice ${ }^{17}$. The offspring was genotyped before the start of the studies to match group sizes and only homozygous Malat ${ }^{+/+}$and Malat $1^{-/-}$mice were used. DNA was isolated from toes of new born mice and genotyping PCR was performed using a standard 3-step protocol with 30 cycles and 62$66^{\circ} \mathrm{C}$ annealing temperature. Primer sequences were: WT-FW AGAGCAGAGCAGCGTAGAGC, WT-Rev GCTCTGGTCAGCCTCCATTA, KO-Fw TTGAAGTGGCGAGCGATAC, and KO-Rev AGATCCCAGCGGTCAAAAC.

Mice were operated at 8-12 weeks of age to induce cardiac hypertrophy by either continuous infusion of angiotensin II (Angll, $2.5 \mathrm{mg} \cdot \mathrm{kg}^{-1} \cdot \mathrm{d}^{-1}$ ) using osmotic minipumps (Alzet) or thoracic aortic constriction (TAC) between the brachiocephalic artery and the left common carotid artery. Aortic diameter was reduced to $0.41 \mathrm{~mm}$ ( $27 \mathrm{G}$ needle) for mice weighing up to $25.5 \mathrm{~g}$ or to $0.46 \mathrm{~mm}$ (26G needle) for larger animals. TAC mimics the situation in patients with aortic valve stenosis with pure pressure overload but without direct hormonal effects. On the other hand, Angll infusion causes systemic hypertension and additionally has direct cellular effects in heart tissue which further promote heart failure ${ }^{30}$. In both studies the duration of the experiment was 4 weeks and sham operated animals served as controls. Conscious heart rate and blood pressure of mice enrolled in the Angll study were measured by CODA tail cuff (Kent Scientific) three weeks after surgery. After four weeks of pressure overload, echocardiography was performed on a Vevo2100 system (Visualsonics) to acquire M-mode images at the height of the papillary muscles. Afterwards, animals were sacrificed to harvest organs for histological analysis and RNA isolation. All animal experiments were carried out in accordance with Dutch law and approved by the animal experimental committee at Maastricht University (permit number 2012-007).

\section{Histology}

After sacrifice, organs were rinsed in PBS and Zinc fixed for 48 hours (BD Pharmingen, \#552658). $4 \mu \mathrm{m}$ paraffin sections were cut to analyze histological changes of the left ventricle and septum. Collagen was stained with Picrosirius Red F3B (Klinipath, \#80115) and interstitial collagen area was quantified after exclusion of vessels and endo- and epicardial connective tissue. Laminin staining was performed using rabbit anti-mouse laminin (Sigma, L9393, 1:100) and Vectastain Elite ABC kit (Vector laboratories) to assess cardiomyocyte size. Epicardial cardiomyocytes as well as longitudinal cells and cells without visible nucleus were excluded from cell size analysis. CD45 positive cells were stained with rat anti-mouse CD45 antibody (BD Pharmingen, \#553076, 1:500) and Vectastain ABC-AP kit (Vector laboratories) and counted in the whole LV and septum. Capillaries were stained with biotinylated Griffonia (Bandeiraea) Simplicifolia Lectin I (Vector Laboratories, B-1105, $20 \mu \mathrm{g} / \mathrm{mL}$ ) and Vectastain ABC-AP kit and cross-sectioned capillaries near the endocardium were counted. All analysis was performed in a blinded manner using a Leica DM2000 equipped with a Leica DFC450C camera and ImageJ software. 


\section{$R T-P C R$ and analysis of alternative splicing}

Myocardial RNA was isolated using mirVana microRNA isolation kit (Ambion) according to manufacturer's instructions. RNA was reverse transcribed using iScript RT kit (Biorad) and RT-qPCR was performed using SYBR Green (Biorad). Primer sequences for Malat1 and for cardiac hypertrophy markers Atrial natriuretic peptide (Nppa), Brain natriuretic peptide $(N p p b)$ and Skeletal alpha actin (Acta1) were: Malat1_Fw CTTTTCCCCCACATTTCCAA, Malat1_Rev CTCGTGGCTCAAGTGAGGTG; Nppa_Fw ATTGACAGGATTGGAGCCCAGAGT, Nppa_Rev TGACACACCACAAGGGCTTAGGAT; Nppb_Fw GTTTGGGCTGTAACGCACTGA, Nppb_Rev GAAAGAGACCCAGGCAGAGTCA; Acta1_Fw TGAGACCACCTACAACAGCA, Acta1_Rev CCAGAGCTGTGATCTCCTTC. Gene expression was normalized to Cyclophilin-A (Ppia) as internal control: Ppia_Fw CAAATGCTGgACCAAACACAA, Ppia_Rev GCCATCCAGCCATTCAGTCT.

Alternative mRNA splicing of $\mathrm{N}$-myc downstream-regulated gene 2 (Ndrg2) and Eukaryotic translation initiation factor $4 \mathrm{H}$ (Eif4h) has been reported in hypertrophic and failing mouse hearts, respectively ${ }^{31,32}$. 500 ng of RNA was reverse-transcribed using Oligo(dT) primers and Superscript II reverse transcriptase (Invitrogen). Primers based on mouse Ndrg2 (exon 1 Fw: TCAAAGGCAAGTGAAGGTGG, exon 4 Rev: CGAGCCATAAGGTGTCTCCA) and Eif4h (exon 3 Fw: GTGGATTCCCTGAAGGAGGC, exon 6 Rev: GAAAGCGACTCCCCATTGGA) were used to detect splicing changes. PCR amplification was performed at $58^{\circ} \mathrm{C}$ for 30 and 35 cycles, respectively. Electrophoretically separated PCR products were quantified by densitometric analysis using ImageJ software and the ratio of the mRNA isoforms (long/short) was calculated.

\section{Statistics}

Data are presented as median and range with individual data points depicted. Statistical analysis was performed using Prism (GraphPad) and SPSS (IBM). Equality of variances was tested by Levene's test. One-way ANOVA (with Welch's correction if appropriate) followed by Tukey or Games-Howell post-hoc test was deployed to compare groups with equal or unequal variances, respectively. In all cases a $p$-value $<0.05$ was considered statistically significant.

\section{Results}

\section{Pressure overload-induced heart failure develops independently of Malat1}

Four weeks after TAC surgery, the effect of LV pressure overload on cardiac dimensions and function were assessed by echocardiography. Both Malat1 WT and KO mice showed a significant increase in cardiac mass and wall thickness (Figure 1A-C). Impaired heart function was evidenced by reduced fractional shortening of the left ventricle and in some cases by backward failure leading to lung edema (Figure 1D-E). Importantly, the degree of hypertrophy and dysfunction did not significantly differ between WT and Malat1 KO mice. Similarly, chronic infusion of angiotensin II for four weeks induced comparable degrees of hypertrophy and left ventricular dysfunction in Malat1 WT and KO mice (Figure S1A-F). A summary of animal characteristics, including organ weights can be found in Table S1. In 
conclusion, absence of Malat1 in mice does not affect the development of heart failure upon pressure overload.

A

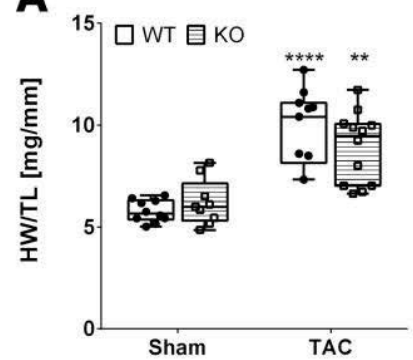

D

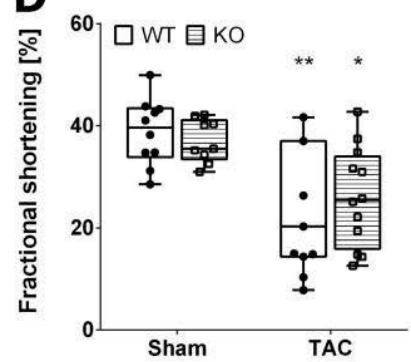

B

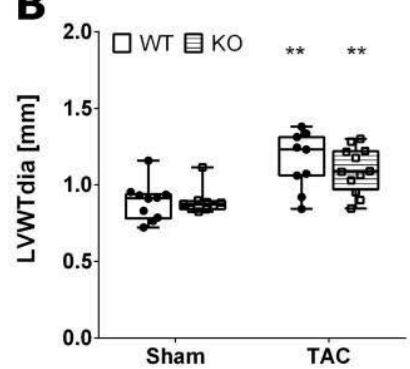

$\mathbf{E}$

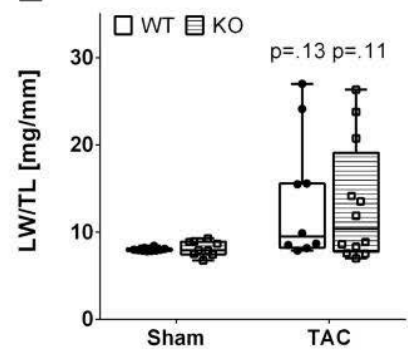

C

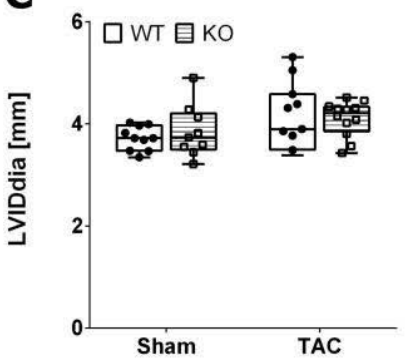

$\mathbf{F}$

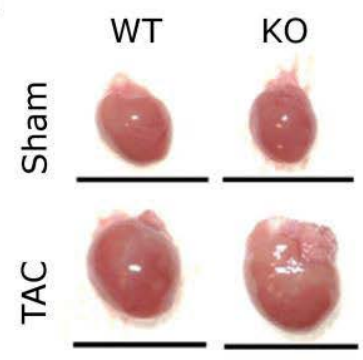

Figure 1: Gross morphological and functional analysis of Malat1 WT and KO hearts after TAC. Increased heart weight/tibia length (A) and diastolic LV wall thickness (B) confirm concentric hypertrophy in both Malat1 WT and KO mice without effects on diastolic LV inner diameter (C). Decreased fractional shortening (D) and lung congestion with increased lung weight/tibia length in some animals (E) indicate heart failure independent of Malat1 deficiency. (F) Representative photographs of mouse hearts, Scale bar: $1 \mathrm{~cm}$.

${ }^{*} p<0.05,{ }^{* *} p<0.01,{ }^{* * * *} p<0.0001$ TAC versus Sham. 


\section{Myocardial remodeling during pressure overload is independent of Malat1}

Hallmarks of maladaptive cardiac remodeling, including cardiomyocyte hypertrophy, interstitial fibrosis, capillary density, and immune cell infiltration was assessed in heart tissue slides four weeks after induction of pressure overload. Hypertrophy of cardiomyocytes was apparent upon TAC and was unaffected by knockout of Malat1 (Figure 2A). Similarly, Angll caused a comparable increase in cardiomyocyte area in both Malat1 WT and KO mice (Figure S2A). The fraction of interstitial collagen area as assessed by staining with Sirius Red was increased significantly after both TAC and Angll, and was independent of Malat1 expression (Figure 2B and Figure S2B). Capillary density was significantly reduced by TAC in WT mice and showed a similar trend in Malat1 KO mice, signifying the transition towards heart failure (Figure 2C). However, no significant difference could be found between the two genotypes, suggesting no effect of Malat1 deficiency on myocardial microvascular perfusion during pressure overload. Finally, while TAC increased the influx of CD45 ${ }^{+}$immune cells into the heart, Malat1 deficiency did not affect the number of cardiac CD45 ${ }^{+}$cells (Figure 2D). In this genetic background, Angll had milder effects on capillary density and immune cell infiltration than TAC, but again no effects of Malat1 were identified (Figure S2C-D). Taken together, these findings show that Malat1 is dispensable for cardiac remodeling upon pressure overload. 
A
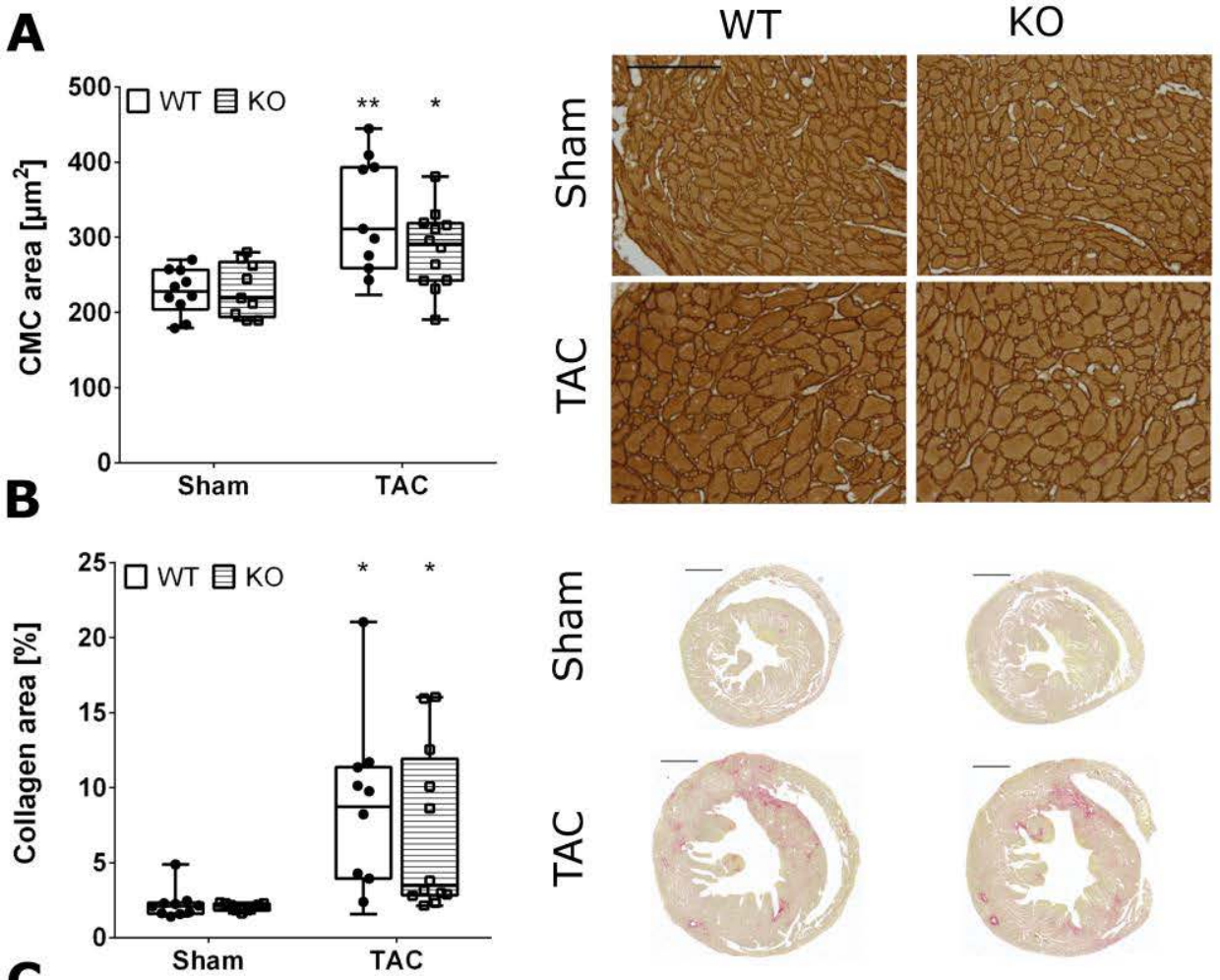

$\frac{\frac{E}{\sigma}}{\frac{\sigma}{n}}$

$\stackrel{U}{\leftarrow}$

C

Sham

$$
\text { TAC }
$$
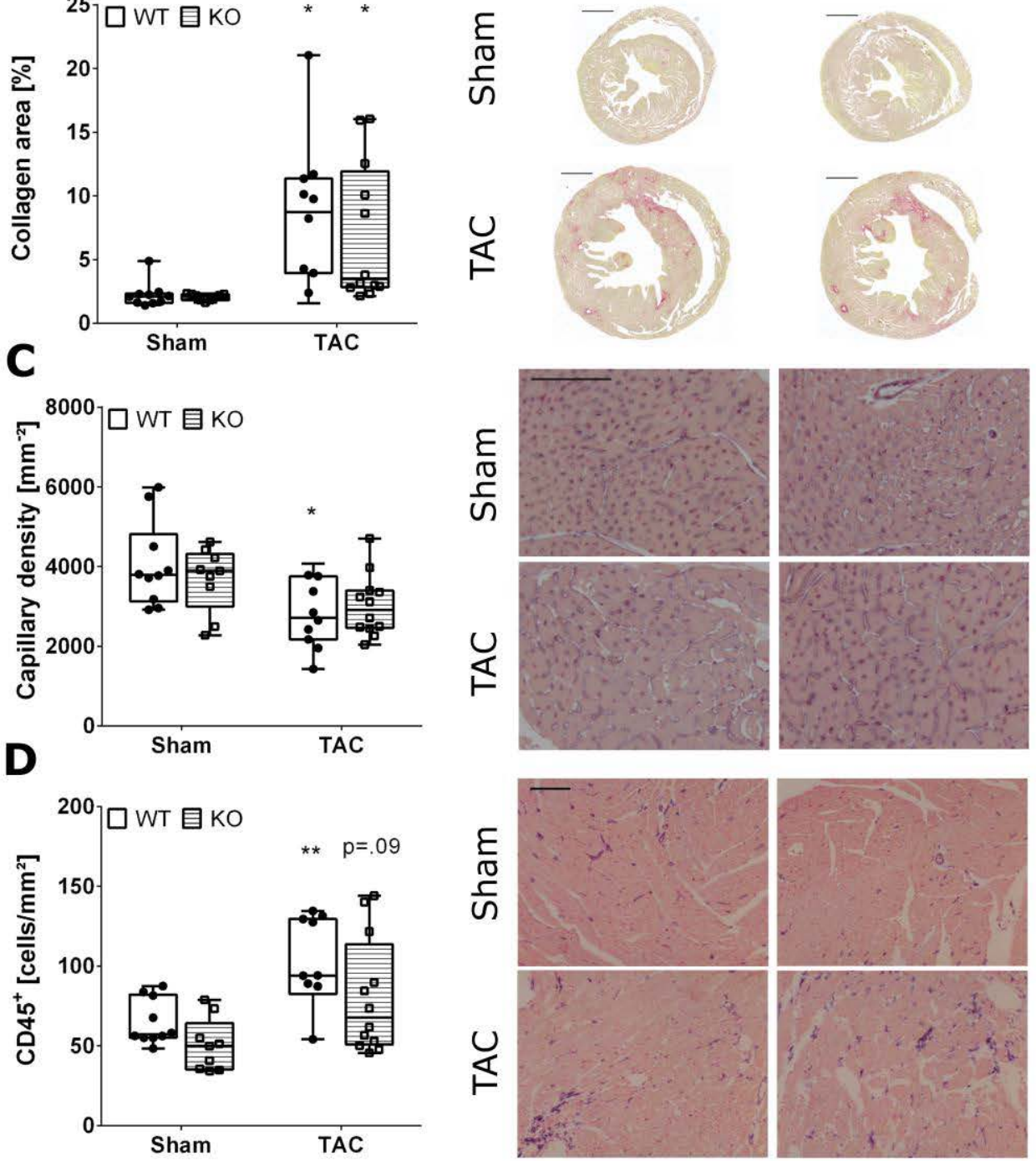

$\stackrel{U}{\vdash}$
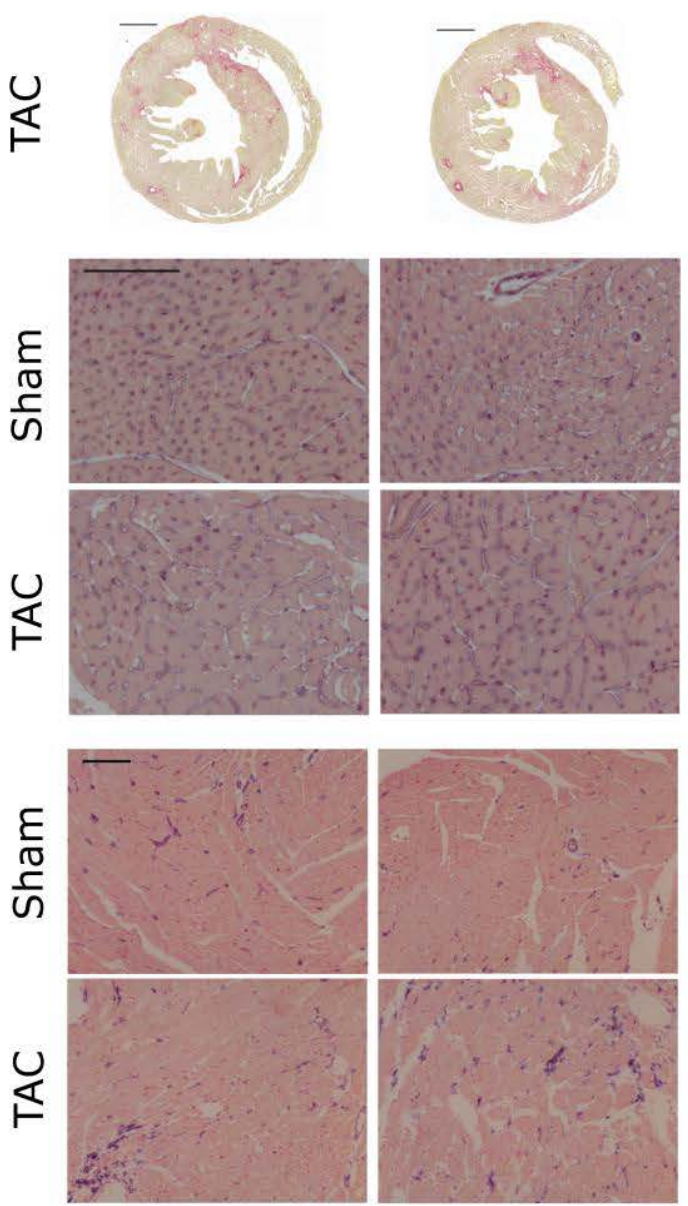
Figure 2: Histological analysis of LV and septal myocardium after TAC. Significant cardiomyocyte hypertrophy (A) and interstitial fibrosis (B) were induced by TAC, whereas the density of endocardial capillaries was mildly decreased (C). (D) Infiltration of CD45 positive leukocytes was apparent after TAC, although this did not reach statistical significance in Malat1 KO mice. Importantly, no significant differences could be detected between Malat1 WT and $\mathrm{KO}$ mice for any of the histological parameters.

${ }^{*} p<0.05,{ }^{* *} p<0.01$ TAC versus Sham. Scale bars: Sirius Red: $1 \mathrm{~mm}$; all other stains: $100 \mu \mathrm{m}$.

\section{Afterload-induced expression of fetal genes is independent of Malat1}

Cardiac hypertrophy goes along with the upregulation of mRNA levels of the natriuretic peptides $\mathrm{A}(\mathrm{Nppa})$ and $\mathrm{B}(\mathrm{Nppb})$ and the cytoskeletal protein skeletal alpha actin (Acta1) in the myocardium. We found mRNA levels of all three hypertrophy markers to be significantly increased after TAC, whereas ablation of Malat1 did not interfere with upregulation of these genes (Figure 3A-C).
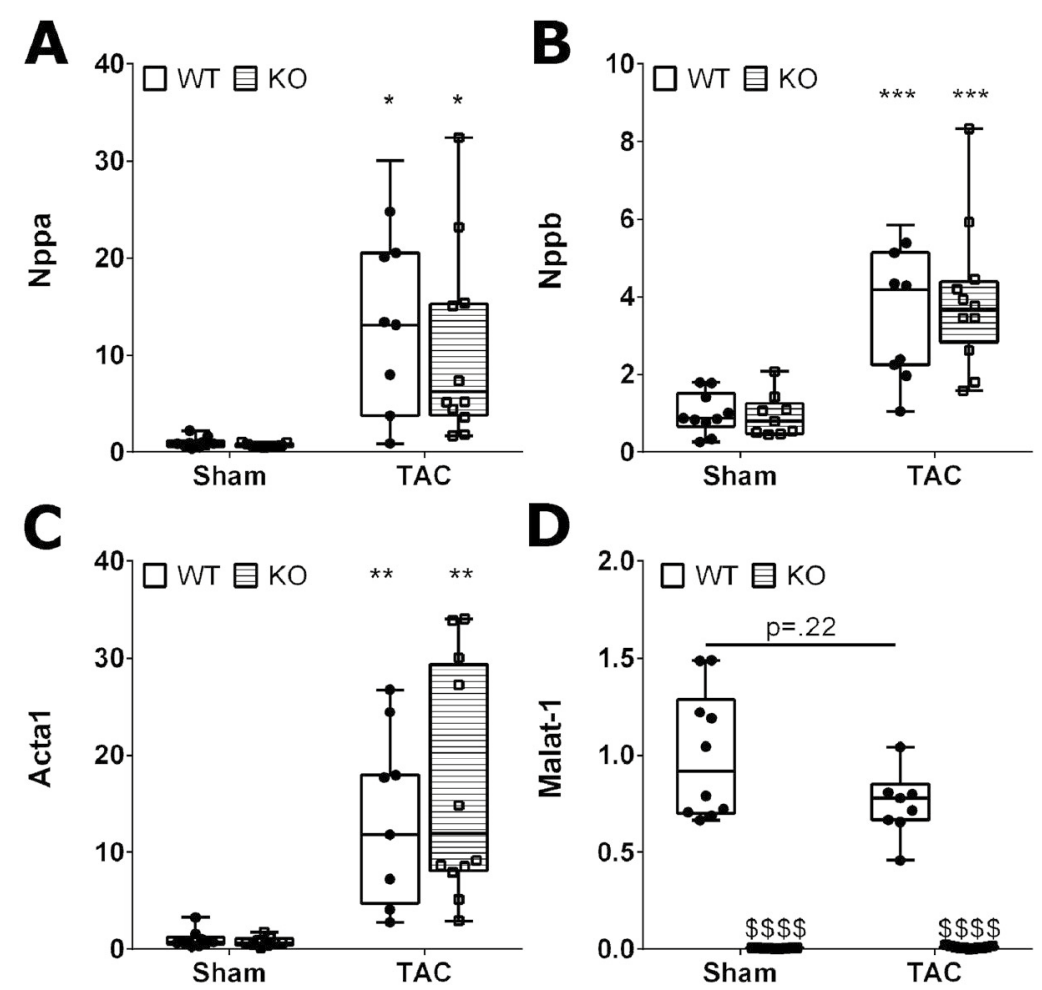

Figure 3: mRNA levels of hypertrophy markers. The hypertrophy marker genes Nppa (A), Nppb (B) and Acta1 (C) were upregulated by TAC and not different between Malat1 WT and KO mice. (D) Malat1 itself was not significantly deregulated after TAC.

${ }^{*} p<0.05,{ }^{* *} p<0.01,{ }^{* * *} p<0.001$ TAC versus Sham; ${ }^{\$ \$ \$} p<0.0001$ KO versus $W T$. 
Next to transcriptional changes, cardiac hypertrophy and failure also induce alternative splicing of certain mRNAs. We measured the fraction of alternatively spliced mRNA of Ndrg2 and Eif4h and found that TAC as expected induced skipping of exon 3 of $\mathrm{Ndrg} 2$, as well as inclusion of exon 5 of Eif4h 31,32. Interestingly, Ndrg2 showed a higher splice ratio in Malat1 KO mice both with and without pressure overload (Figure 4A-C) confirming a role of Malat1 in splicing, whereas the splicing pattern of Eif4h was not different between genotypes.
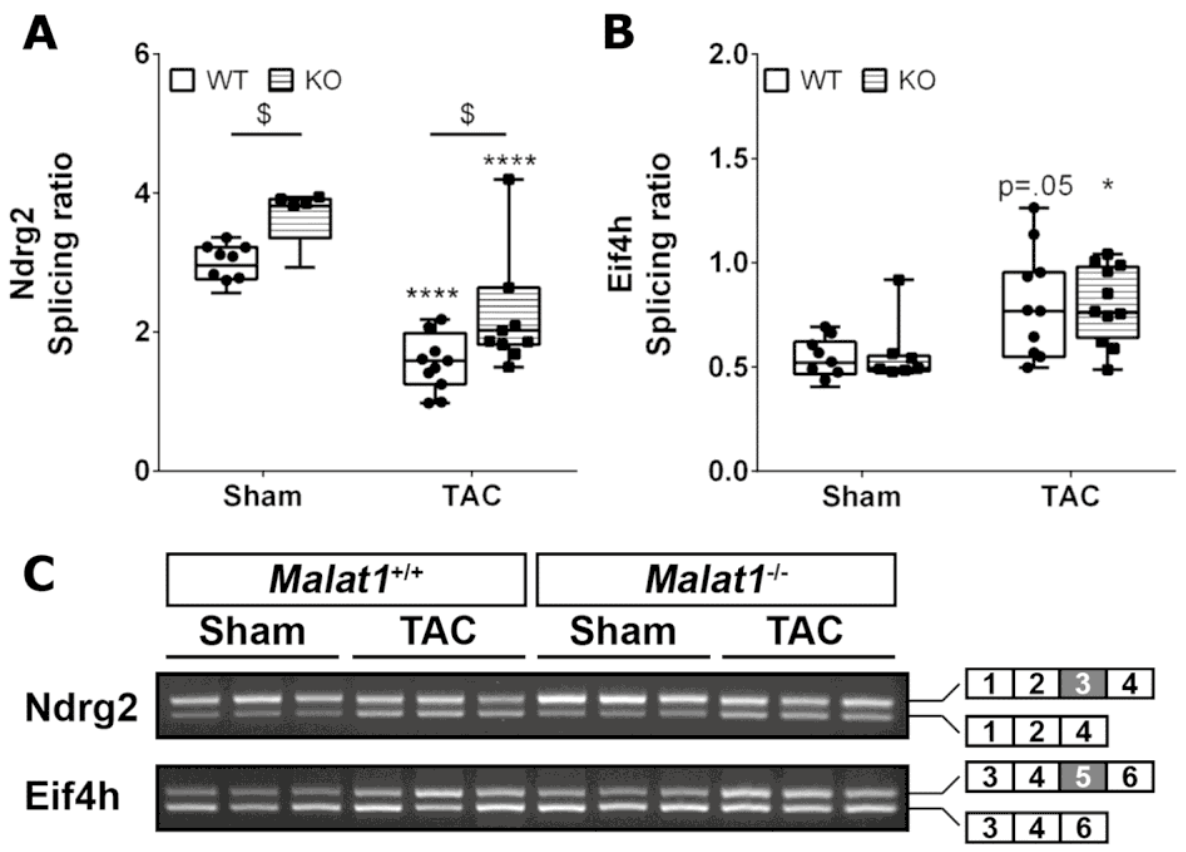

Figure 4: Alternative splicing of Ndrg2 and Eif4h is evident after TAC. (A) Skipping of Ndrg2 exon 3 is apparent after TAC in Malat1 WT and KO mice, but absence of Malat1 reduces this event both at baseline and after pressure overload. (B) Exon 5 inclusion of Eif $4 h$ is induced by TAC but not affected by absence of Malat1. (C) Representative images of PCR products of Eif4h and Ndrg2.

${ }^{*} p<0.05,{ }^{* * * *} p<0.0001$ TAC versus Sham; ${ }^{\$} p<0.05$ KO versus $W T$.

\section{Discussion}

Long non-coding RNAs are emerging as important players in several pathologic conditions, such as cancer and cardiovascular disorders. The nuclear IncRNA Malat1 is exceptionally well-conserved among vertebrates and abundantly expressed in most organs and cell types investigated so far, implying an important role throughout evolution. However, different approaches to knockout Malat1 in mice have shown no effect on development and normal life ${ }^{15-17}$, leading researchers to assume that Malat1 becomes relevant only under stressed conditions. Heart failure is the final end stage of many cardiac diseases and a major cause of death worldwide. We investigated the effect of genetic ablation of Malat1 on molecular, 
histological, morphological, and functional changes during development of heart failure in two different mouse models. Although we confirm a role for Malat1 in mRNA splicing, we found that this IncRNA has no crucial role in pressure overload induced cardiac hypertrophy and failure.

In vivo, Malat1 abrogation was recently found to cause aberrant vessel growth in a model of hind limb ischemia ${ }^{22}$. However, the functional relevance of this finding was not assessed in the study. In the pressure-overloaded heart, a transient increase in capillary density and concomitant improved perfusion is indispensable for development of compensated hypertrophy and maintained cardiac function ${ }^{19}$. Therefore, we expected Malat1 to accelerate heart failure development by impeding the compensatory response of capillary growth upon pressure overload. However, while four weeks of TAC resulted in heart failure with decreased capillary density, we found no role for Malat1 in regulating cardiac capillary density both under normal physiological and under pressure overloaded conditions. Next to vessel growth, Malat1 is essential for proliferation and migration of several cancer cell lines and was reported to activate the ERK/MAPK growth signaling pathway ${ }^{29}$, which is wellknown for its central role in cardiomyocyte hypertrophy. Additionally, Malat1 has been proposed to act as a competing endogenous RNA for microRNA-133, thereby attenuating miR-133 mediated repression of serum response factor (SRF) ${ }^{24}$. The muscle-specific miR133 has critical functions in the heart and is a powerful inhibitor of cardiac hypertrophy ${ }^{25,26,33}$ and the transcription factor SRF is an important regulator of several hypertrophy associated genes, such as Nppa, Nppb and Acta ${ }^{34}$. However, our findings indicate no role of Malat1 on transcriptional changes or on overall cardiac hypertrophy during pressure overload. These findings argue against a relevant influence of Malat1 on ERK/MAPK signaling or miR$133 /$ SRF regulation in the heart.

Cardiac pro-hypertrophic signaling together with cardiomyocyte damage leads to the activation of resident fibroblasts and deposition of interstitial connective tissue. Indeed, both Angll and TAC induced myocardial collagen deposition and ablation of Malat1 did not affect this process, ruling out an important role of this IncRNA in fibroblast activation. Additionally, the number of $\mathrm{CD} 45^{+}$cells in the pressure-overloaded heart was not affected by presence or absence of Malat1, although a role for Malat1 in pro-inflammatory cytokine production by HUVECS has recently been suggested ${ }^{35}$. On the cellular level, knockdown of Malat 1 results in alternative splicing of several genes ${ }^{14}$, and in line with this, it was found that Malat1 colocalizes with the splicing factors ASF/SF2 in nuclear speckles of mouse embryonic fibroblasts and cultured neurons ${ }^{36}$. Interestingly, a deficiency of ASF/SF2 has been shown to alter cardiomyocyte function by affecting splicing of calcium/calmodulin-dependent kinase $1 I \delta^{37}$ and perturbation of mRNA splicing is a feature of heart failure ${ }^{38}$. Interestingly, we found alternative splicing of Ndrg2, which shows skipping of exon 3 in hypertrophic mouse hearts ${ }^{31}$, to be less common in Malat1 $\mathrm{KO}$ mice both at baseline and after pressure overload. In contrast, alternative splicing of Eif4h was apparent after pressure overload as previously reported ${ }^{32}$ but not affected by ablation of Malat1. These data confirm that Malat 1 can influence splicing of individual mRNAs but do not indicate an important role of this effect in cardiac pressure overload. The named molecular and histological changes entail effects on cardiac morphology and function both in Malat1 WT and KO mice. Our echocardiographic analysis is limited to systolic function, but in view of the comparable cardiomyocyte hypertrophy and myocardial fibrosis it appears unlikely that diastolic function 
is affected by absence of Malat1. In conclusion, despite extensive phenotyping of cardiac function, morphology, histological appearance, and gene expression, no important differences could be found in the hearts of Malat1 WT and KO mice after TAC- or Angllinduced cardiac pressure overload.

While this manuscript was in preparation, another group reported that inhibition of Malat1 may have protective effects on LV dilation and dysfunction in a model of streptozotocininduced diabetic cardiomyopathy. This was associated with dampening of cytokine expression and cardiomyocyte apoptosis ${ }^{39,40}$. However, no information was given on possible cell types and signaling pathways responsible for this effect, which impedes a proper comparison with other findings. Above that, the power and relevance of these two short reports are difficult to assess due to the lack of information on data presentation and statistical analysis. Therefore, more detailed knowledge is needed to reconcile a possible role of Malat1 in diabetic cardiomyopathy with its insignificance during pressure overloadinduced cardiac hypertrophy and failure.

Interestingly, only an effect of Malat1 on vascularization of the retina was shown in Malat1 $\mathrm{KO}$ mice ${ }^{22}$, whereas its functions in hind limb ischemia, ERK/MAPK signaling, miR-133 scavenging, and possibly diabetic cardiomyopathy were exclusively shown by posttranscriptional knockdown of Malat ${ }^{22-24,29,39,40}$. It is therefore conceivable that compensatory pathways are activated in Malat1 KO mice during embryonic development that allow for normal cardiac function and adaptation in our study. Inducible knock-out strategies or deep RNA sequencing may help to circumvent and to identify possible compensatory mechanisms, respectively. Importantly, the nature of such compensatory changes would directly help to deduce the regular function of Malat1. Above that, phenotypical changes upon deletion of a IncRNA can depend on the knockout strategy employed, which constitutes a major difficulty for investigating IncRNA functions in vivo ${ }^{41}$. Subtle phenotypical differences have been observed between the three different Malat1 knockout lines generated so far $^{42}$ and it is therefore conceivable that the promoter or other parts of the Malat1 locus may have a function independent of the actual Malat1 transcript. However, our results clearly show that the Malat1 IncRNA transcript is dispensable during pressure overload induced cardiac hypertrophy and dysfunction. While we cannot exclude transcript-independent functions of the Malat1 locus or the existence of compensatory mechanisms, our findings suggest no important role for Malat1 in heart failure.

\section{Conclusions}

We deployed two mouse models of pressure overload-induced heart failure to investigate the function of the IncRNA Malat1 in a highly relevant human disease. Despite its reported function as regulator of vascularization, activator of ERK/MAPK signaling, and scavenger for the muscle-specific miR-133, we conclude that Malat1 has no important role for cardiac hypertrophy and failure in vivo. Our findings therefore stress the importance of validating proposed IncRNA functions in clinically relevant disease models. 


\section{References}

1. Taft, R. J., Pheasant, M. \& Mattick, J. S. The relationship between non-protein-coding DNA and eukaryotic complexity. Bioessays 29, 288-299 (2007).

2. Mattick, J. S. The central role of RNA in human development and cognition. FEBS Lett. 585, 1600-1616 (2011).

3. Brockdorff, N. et al. The product of the mouse Xist gene is a $15 \mathrm{~kb}$ inactive X-pecific transcript containing no conserved ORF and located in the nucleus. Cell 71, 515-526 (1992).

4. Brown, C. J. et al. The human XIST gene: Analysis of a $17 \mathrm{~kb}$ inactive X-specific RNA that contains conserved repeats and is highly localized within the nucleus. Cell 71, 527-542 (1992).

5. Grote, P. \& Herrmann, B. G. Long noncoding RNAs in organogenesis: making the difference. Trends Genet. 31, 329-335 (2015).

6. Yang, G., Lu, X. \& Yuan, L. LncRNA: A link between RNA and cancer. Biochim Biophys Acta 1839, 10971109 (2014).

7. Peters, T. \& Schroen, B. Missing links in cardiology: long non-coding RNAs enter the arena. Pflugers Arch 466, 1177-1187 (2014).

8. Thum, T. \& Condorelli, G. Long noncoding RNAs and microRNAs in cardiovascular pathophysiology. Circ. Res. 116, 751-762 (2015).

9. Ji, P. et al. MALAT-1, a novel noncoding RNA, and thymosin $\beta 4$ predict metastasis and survival in earlystage non-small cell lung cancer. Oncogene 22, 8031-8041 (2003).

10. Gutschner, T., Hämmerle, M. \& Diederichs, S. MALAT1 - a paradigm for long noncoding RNA function in cancer. J Mol Med 91, 791-801 (2013).

11. Wu, Y. et al. Prognostic value of long non-coding RNA MALAT1 in cancer patients. Tumour Biol 37, 897903 (2016).

12. West, J. A. et al. The Long Noncoding RNAs NEAT1 and MALAT1 Bind Active Chromatin Sites. Mol. Cell 55, 791-802 (2014).

13. Hutchinson, J. N. et al. A screen for nuclear transcripts identifies two linked noncoding RNAs associated with SC35 splicing domains. BMC Genomics 8, 39 (2007).

14. Tripathi, V. et al. The nuclear-retained noncoding RNA MALAT1 regulates alternative splicing by modulating SR splicing factor phosphorylation. Mol. Cell 39, 925-938 (2010).

15. Zhang, B. et al. The IncRNA Malat1 is dispensable for mouse development but its transcription plays a cisregulatory role in the adult. Cell Rep. 2, 111-123 (2012).

16. Eißmann, M. et al. Loss of the abundant nuclear non-coding RNA MALAT1 is compatible with life and development. RNA Biol. 9, 1076-87 (2012).

17. Nakagawa, S. et al. Malat1 is not an essential component of nuclear speckles in mice. RNA 18, 1487-1499 (2012).

18. Bui, A. L., Horwich, T. B. \& Fonarow, G. C. Epidemiology and risk profile of heart failure. Nat. Rev Cardiol 8, 30-41 (2010).

19. Sano, M. et al. p53-induced inhibition of Hif-1 causes cardiac dysfunction during pressure overload. Nature 446, 444-448 (2007). 
20. Giordano, F. J. et al. A cardiac myocyte vascular endothelial growth factor paracrine pathway is required to maintain cardiac function. Proc Natl Acad Sci USA 98, 5780-5785 (2001).

21. Yoon, Y. et al. Progressive Attenuation of Myocardial Vascular Endothelial Diabetic Cardiomyopathy Restoration of Microvascular Homeostasis and Recovery of Cardiac Function in Diabetic Cardiomyopathy After Replenishment of Local vascular endothelial growth factor. Circulation 111, 2073-2085 (2005).

22. Michalik, K. M. et al. Long noncoding RNA MALAT1 regulates endothelial cell function and vessel growth. Circ Res 114, 1389-1397 (2014).

23. Watts, R., Johnsen, V. L., Shearer, J. \& Hittel, D. S. Myostatin-induced inhibition of the long noncoding RNA Malat1 is associated with decreased myogenesis. Am J Physiol Cell Physiol 304, 995-1001 (2013).

24. Han, X., Yang, F., Cao, H. \& Liang, Z. Malat1 regulates serum response factor through miR-133 as a competing endogenous RNA in myogenesis. FASEB J 29, 3054-3064 (2015).

25. Castaldi, A. et al. MicroRNA-133 modulates the $\beta 1$-adrenergic receptor transduction cascade. Circ Res 115, 273-283 (2014).

26. Carè, A. et al. MicroRNA-133 controls cardiac hypertrophy. Nat Med 13, 613-618 (2007).

27. Zhang, $X$. et al. Cardiomyopathy in transgenic mice with cardiac- specific overexpression of serum response factor. Am J Physiol Hear. Circ Physiol 280, 1782-1792 (2001).

28. Muslin, A. MAPK signalling in cardiovascular health and disease: molecular mechanisms and therapeutic targets. Clin Sci 115, 203-218 (2008).

29. Wu, X. et al. MALAT1 promotes the proliferation and metastasis of gallbladder cancer cells by activating the ERK / MAPK pathway. Cancer Biol Ther 15, 806-814 (2014).

30. Kurdi, M. \& Booz, G. W. New Take on the Role of Angiotensin II in Cardiac Hypertrophy and Fibrosis. Hypertension 57, 1034-1038 (2011).

31. Song, H. K., Hong, S. E., Kim, T. \& Kim, D. H. Deep RNA sequencing reveals novel cardiac transcriptomic signatures for physiological and pathological hypertrophy. PLOS One 7, e35552 (2012).

32. Lee, J. H. et al. Analysis of transcriptome complexity through RNA sequencing in normal and failing murine hearts. Circ. Res. 109, 1332-1341 (2011).

33. Townley-tilson, W. H. D., Callis, T. E. \& Wang, D. MicroRNAs 1, 133 , and 206: Critical factors of skeletal and cardiac muscle development, function, and disease. Int J Biochem Cell Biol 42, 1252-1255 (2010).

34. Nelson, T. J., Balza, R. J., Xiao, Q. \& Misra, R. P. SRF-dependent gene expression in isolated cardiomyocytes: Regulation of genes involved in cardiac hypertrophy. J Mol Cell Cardiol 39, 479-489 (2005).

35. Puthanveetil, P., Chen, S., Feng, B., Gautam, A. \& Chakrabarti, S. Long non-coding RNA MALAT1 regulates hyperglycaemia induced inflammatory process in the endothelial cells. J Cell Mol Med 19, 1418-1425 (2015).

36. Bernard, D. et al. A long nuclear-retained non-coding RNA regulates synaptogenesis by modulating gene expression. EMBO J 29, 3082-3093 (2010).

37. $\mathrm{Xu}, \mathrm{X}$. et al. ASF/SF2-Regulated CaMKIld Alternative Splicing Temporally Reprograms ExcitationContraction Coupling in Cardiac Muscle. Cell 120, 59-72 (2005).

38. Kong, S. W. et al. Heart Failure - Associated Changes in RNA Splicing of Sarcomere Genes. Circ Cardiovasc Genet 3, 138-146 (2010). 
39. Zhang, M., Gu, H., Chen, J. \& Zhou, X. Involvement of long noncoding RNA MALAT1 in the pathogenesis of diabetic cardiomyopathy. Int. J. Cardiol. 202, 753-755 (2016).

40. Zhang, M., Gu, H., Xu, W. \& Zhou, X. Down-regulation of IncRNA MALAT1 reduces cardiomyocyte apoptosis and improves left ventricular function in diabetic rats. Int. J. Cardiol. 203, 214-216 (2016).

41. Bassett, A. R. et al. Considerations when investigating IncRNA function in vivo. Elife 14, e03058 (2014).

42. Nakagawa, S. Lessons from reverse-genetic studies of IncRNA. Biochim Biophys Acta 1859, 177-183 (2016). 


\section{Supporting Information}
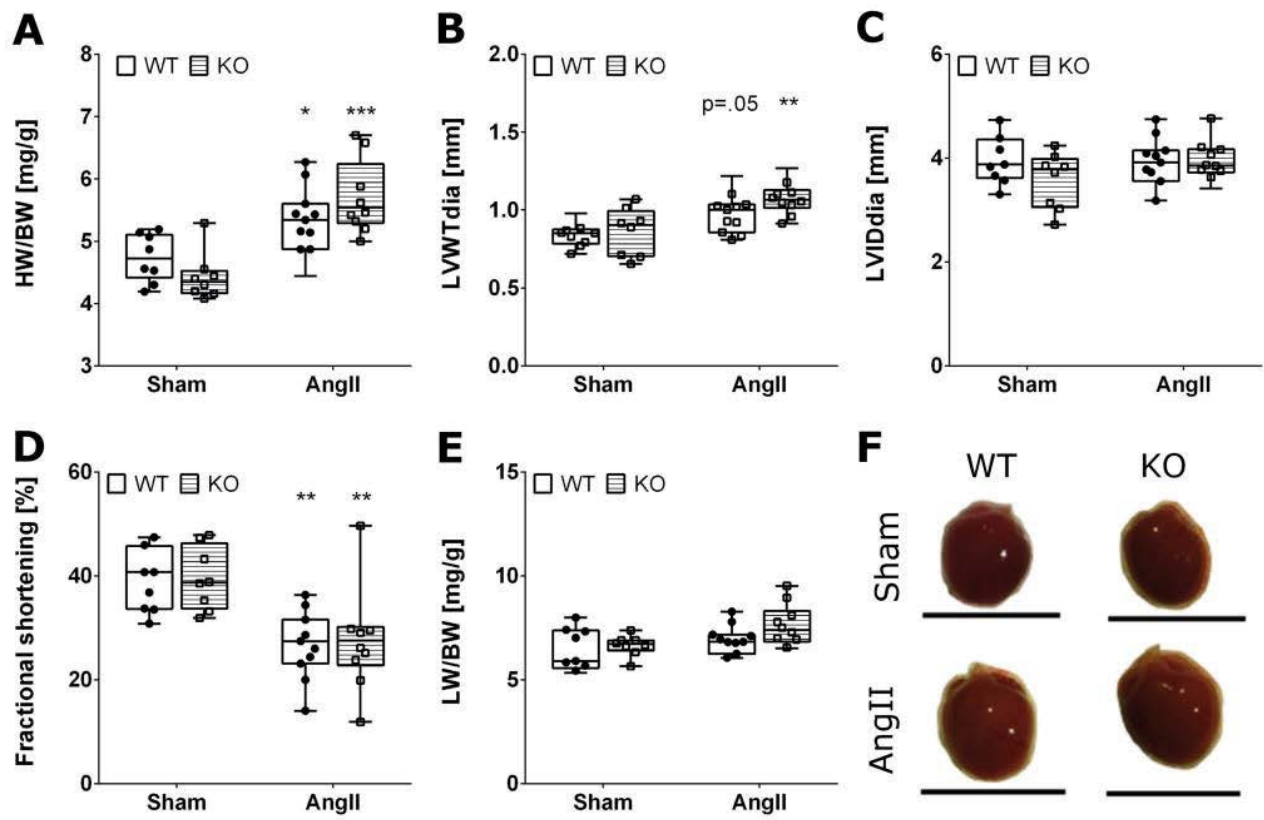

Figure S1: Gross morphological and functional analysis of Malat1 WT and KO hearts after Angll infusion. Increased heart weight/body weight (A) and diastolic left ventricular wall thickness (B) without effects on diastolic left ventricular inner diameter (C) indicate concentric hypertrophy in both Malat1 WT and KO mice. Decreased fractional shortening (D) without increased lung weight/body weight $(E)$ indicate beginning of heart failure independent of Malat1 deficiency. (F) Representative photographs of mouse hearts, Scale bar: $1 \mathrm{~cm}$.

${ }^{*} p<0.05,{ }^{* *} p<0.01,{ }^{* * *} p<0.001$ Angll versus Sham. 

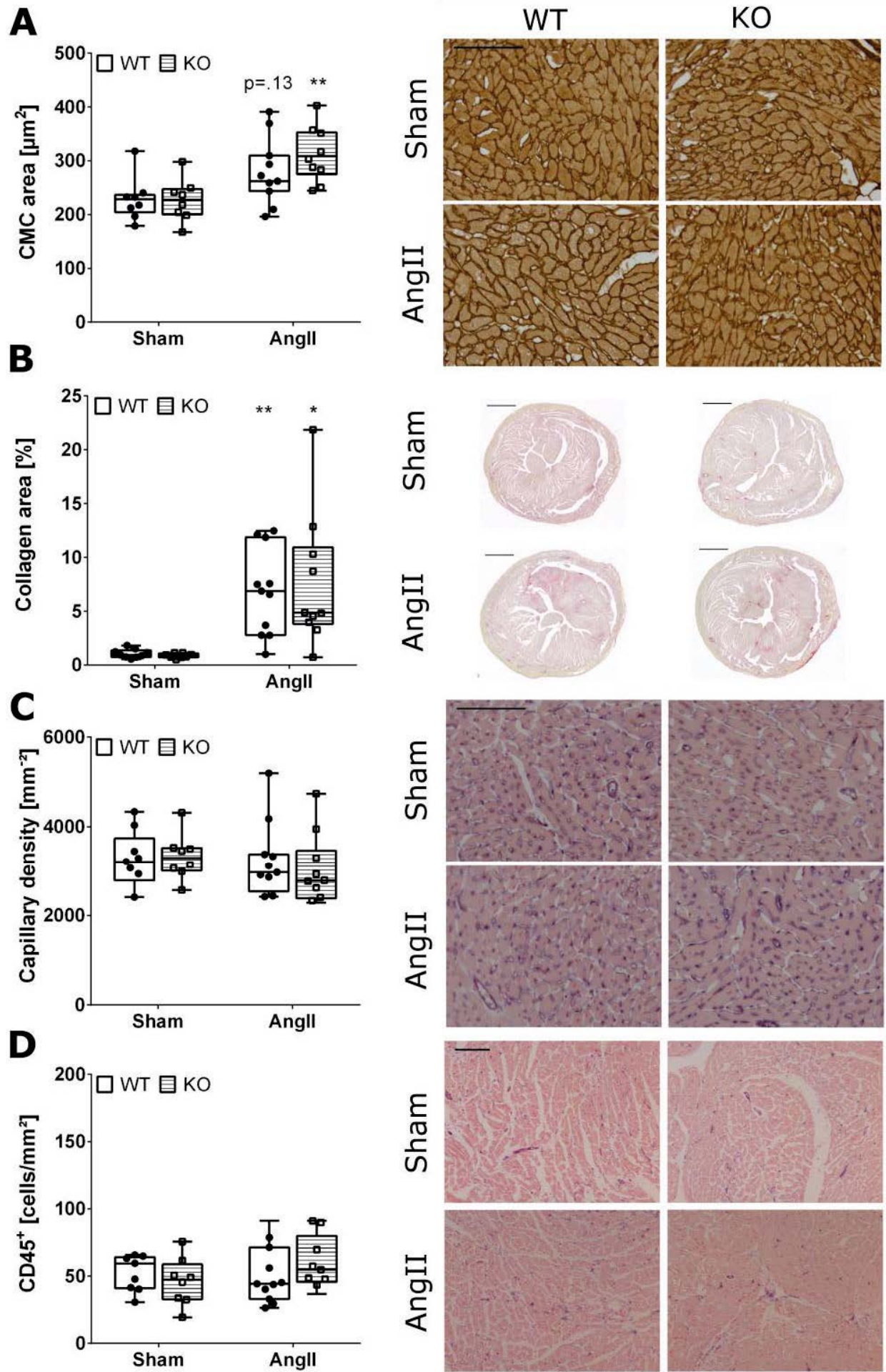
4 Figure S2: Histological analysis of LV and septal myocardium after Angll. No significant differences between WT and Malat1 KO mice were found regarding cardiomyocyte hypertrophy (A), interstitial fibrosis (B), endocardial capillary density (C), or leucocyte infiltration (D).

${ }^{*} p<0.05,{ }^{* *} p<0.01$ Angll versus Sham. Scale bars: Sirius Red: $1 \mathrm{~mm}$; all other stains: $100 \mu \mathrm{m}$. 
Table S1: Characteristics of Malat1 WT and KO mice after sham surgery or pressure overload.

\begin{tabular}{|c|c|c|c|c|c|c|c|c|c|c|c|c|c|c|c|}
\hline \multirow{3}{*}{$\begin{array}{l}\text { Sex } \\
\text { Age at surgery }\end{array}$} & \multirow{3}{*}{$\begin{array}{l}{[\mathrm{m} / \mathrm{f}]} \\
{[\text { weeks] }}\end{array}$} & \multicolumn{3}{|c|}{ WT/Sham } & \multicolumn{3}{|c|}{ WT/TAC } & \multicolumn{4}{|c|}{ KO/Sham } & \multicolumn{4}{|c|}{$\mathrm{KO} / \mathrm{TAC}$} \\
\hline & & \multicolumn{3}{|c|}{ Mean $\begin{array}{c} \pm S D \\
5 / 5 \\
\end{array}$} & \multicolumn{3}{|c|}{$\begin{array}{c}\text { Mean } \pm \text { SD } \\
6 / 5\end{array}$} & \multicolumn{4}{|c|}{$\begin{array}{c}\text { Mean } \pm \text { SD } \\
5 / 4\end{array}$} & \multicolumn{4}{|c|}{$\begin{array}{c}\text { Mean } \pm S D \\
6 / 6\end{array}$} \\
\hline & & 9.0 & \pm & 0.4 & $9.1 \pm$ & \pm 0.4 & & 8.4 & \pm & 0.4 & & 8.6 & \pm & 0.6 & \\
\hline Bodyweight at surgery & [g] & 22.53 & \pm & 2.28 & $22.49 \pm$ & \pm 2.46 & & 21.10 & \pm & 3.39 & & 21.63 & \pm & 3.22 & \\
\hline Tibia lenght (day 28) & {$[\mathrm{mm}]$} & 17.82 & \pm & 0.23 & $17.83 \pm$ & \pm 0.20 & & 17.60 & \pm & 0.49 & & $17.66=$ & \pm & 0.38 & \\
\hline Heart weight & [mg] & 103.10 & \pm & 10.37 & $174.55 \pm$ & \pm 31.97 & & 109.67 & \pm & 22.02 & & 157.58 & \pm & 32.47 & 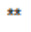 \\
\hline HW/BW & {$[\mathrm{mg} / \mathrm{g}]$} & 4.58 & \pm & 0.23 & $7.83 \pm$ & \pm 1.58 & 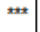 & 5.19 & \pm & 0.41 & $\$$ & 7.28 & \pm & 1.01 & $\approx$ \\
\hline HW/TL & {$[\mathrm{mg} / \mathrm{mm}]$} & 5.78 & \pm & 0.55 & $9.79 \pm$ & \pm 1.82 & 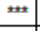 & 6.21 & \pm & 1.12 & & 8.91 & \pm & 1.74 & \pm \\
\hline Lung weight & [mg] & 142.40 & \pm & 4.58 & $231.91 \pm$ & \pm 122.69 & & 143.33 & \pm & 18.46 & & 233.50 & \pm & 122.36 & \\
\hline LW/BW & {$[\mathrm{mg} / \mathrm{g}]$} & 6.36 & \pm & 0.51 & $10.49 \pm$ & \pm 5.87 & & 6.85 & \pm & 0.60 & & 10.65 & \pm & 5.13 & \\
\hline LW/TL & {$[\mathrm{mg} / \mathrm{mm}]$} & 7.99 & \pm & 0.19 & $12.99 \pm$ & \pm 6.82 & & 8.12 & \pm & 0.85 & & $13.18=$ & \pm & 6.81 & \\
\hline Liver weight & [mg] & 1133.30 & \pm & 142.04 & $1023.73 \pm$ & \pm 195.41 & & 1030.00 & \pm & 154.85 & & 1080.00 & \pm & 220.36 & \\
\hline LiW/BW & {$[\mathrm{mg} / \mathrm{g}]$} & 50.28 & \pm & 3.17 & $45.44 \pm$ & \pm 6.43 & & 49.33 & \pm & 6.66 & & $49.92=$ & \pm & 6.59 & \\
\hline LiW/TL & {$[\mathrm{mg} / \mathrm{mm}]$} & 63.57 & \pm & 7.63 & $57.41 \pm$ & \pm 10.88 & & 58.44 & \pm & 7.98 & & 61.07 & \pm & 11.83 & \\
\hline Kidney weight & [mg] & 144.15 & \pm & 17.11 & $146.27 \pm$ & \pm 20.07 & & 158.00 & \pm & 37.97 & & 144.96 & \pm & 22.88 & \\
\hline KW/BW & {$[\mathrm{mg} / \mathrm{g}]$} & 6.39 & \pm & 0.22 & $6.49 \pm$ & \pm 0.31 & & 7.42 & \pm & 0.70 & $\$ \$$ & 6.70 & \pm & 0.46 & \\
\hline KW/TL & {$[\mathrm{mg} / \mathrm{mm}]$} & 8.08 & \pm & 0.91 & $8.20 \pm$ & \pm 1.11 & & 8.94 & \pm & 1.96 & & 8.19 & \pm & 1.18 & \\
\hline Spleen weight & [mg] & 79.70 & \pm & 6.41 & $86.82 \pm$ & \pm 19.04 & & 83.13 & \pm & 20.78 & & $98.25=$ & \pm & 29.44 & \\
\hline SW/BW & {$[\mathrm{mg} / \mathrm{g}]$} & 3.57 & \pm & 0.49 & $3.91 \pm$ & \pm 1.03 & & 3.79 & \pm & 0.82 & & $4.63=$ & \pm & 1.51 & \\
\hline SW/TL & {$[\mathrm{mg} / \mathrm{mm}]$} & 4.47 & \pm & 0.36 & $4.86 \pm$ & \pm 1.04 & & 4.68 & \pm & 1.11 & & $5.56=$ & \pm & 1.64 & \\
\hline Heart rate during echo & [bpm] & 521 & \pm & 41 & $521 \pm$ & \pm 49 & & 506 & \pm & 69 & & $535=$ & \pm & 33 & \\
\hline Fractional shortening & [\%] & 38.81 & \pm & 6.53 & $23.14 \pm$ & \pm 11.99 & $*$ & 37.01 & \pm & 4.19 & & 25.98 & \pm & 9.75 & $*$ \\
\hline Diastolic LV wall thickness & {$[\mathrm{mm}]$} & 0.89 & \pm & 0.24 & $1.16 \pm$ & \pm 0.18 & \pm & 0.89 & \pm & 0.09 & & $1.10=$ & \pm & 0.15 & 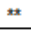 \\
\hline Diastolic LV inner diameter & {$[\mathrm{mm}]$} & 3.72 & \pm & 0.12 & $4.14 \pm$ & \pm 0.64 & & 3.85 & \pm & 0.51 & & $4.10=$ & \pm & 0.34 & \\
\hline
\end{tabular}




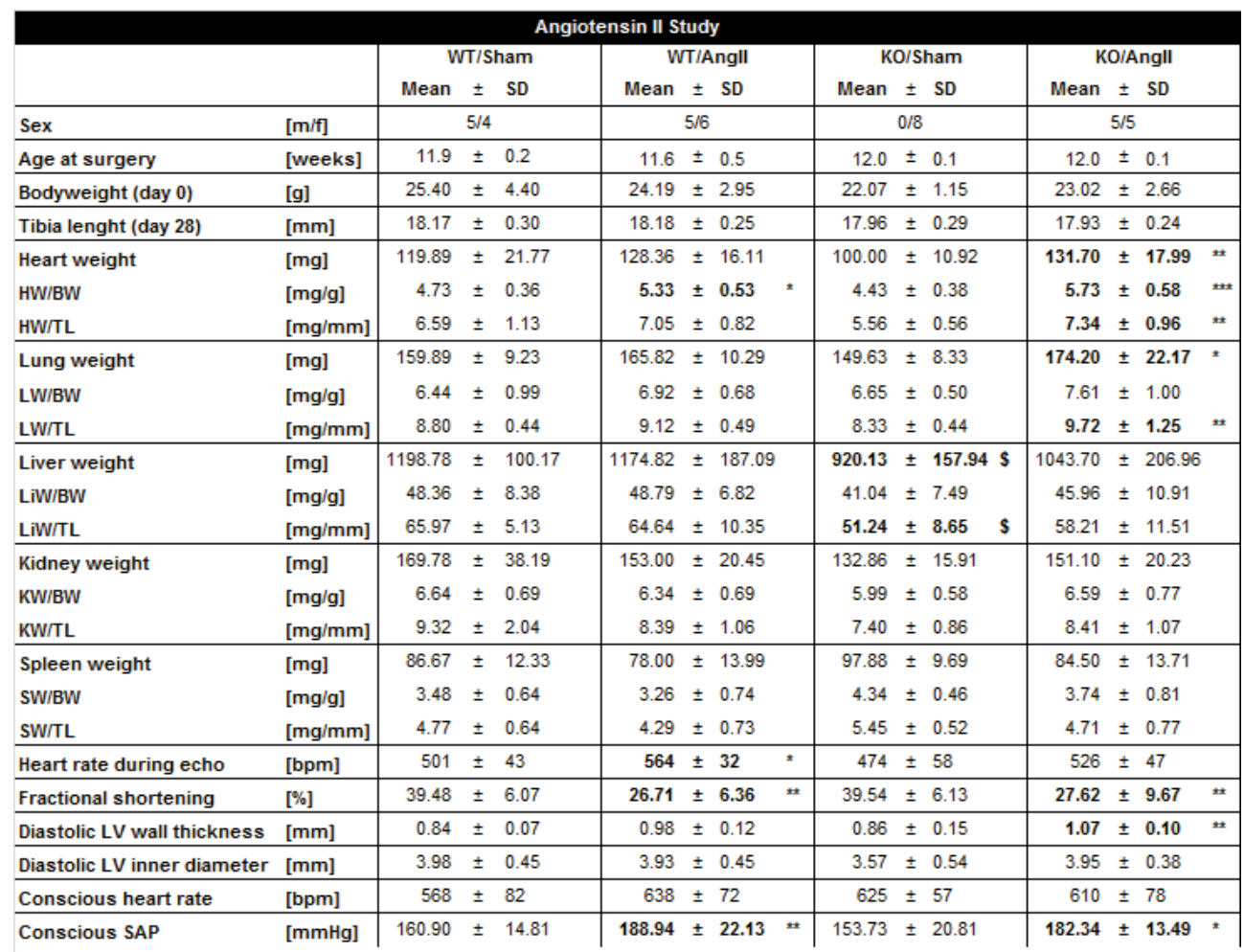

$\begin{array}{lrr}{ }^{*} p<0.05 \text { vs Sham } & \text { S } p<0.05 \text { vs WT } & { }^{*} p<0.05 \text { vs Sham } \\ { }^{* *} p<0.01 \text { vs Sham } & \text { SS } p<0.01 \text { vs WT } & { }^{* \pm} p<0.01 \text { vs Sham } \\ & & { }^{* * *} p<0.001 \text { vs Sham }\end{array}$

Table S2: Complete dataset used to generate the graphs.

Please find further details on the complete dataset online:

https://doi.org/10.1371/journal.pone.0150236.s004 



\section{Chapter 4}

\section{Absence of long non-coding RNA}

Neat1 protects from pressure

overload-induced cardiac

remodelling and failure

Steffie Hermans-Beijnsberger ${ }^{1}$, Rick van Leeuwen ${ }^{1}$, Monika Rech ${ }^{1}$, Wouter Verhesen ${ }^{1}$, Edward Corrigan ${ }^{1}$, Cindya Perthy Iswandi ${ }^{1}$, Shinichi Nakagawa $^{3}$, Marc van Bilsen ${ }^{1,2}$, Blanche Schroen ${ }^{1}$

1 Department of Cardiology, CARIM School for Cardiovascular Diseases, Maastricht University, Universiteitssingel 50, 6200 MD Maastricht, the Netherlands.

2 Department of Physiology, CARIM School for Cardiovascular Diseases, Maastricht University, Universiteitssingel 50, 6200 MD Maastricht, the Netherlands

3 RNA Biology Laboratory, Faculty of Pharmaceutical Sciences, Hokkaido University, Sapporo, Japan

In preparation 


\section{Chapter 5}

\section{The tRNA-like molecule, mascRNA, affects cardiomyocyte cell cycle progression and viral replication}

Steffie Hermans-Beijnsberger ${ }^{1}$, Wouter Verhesen ${ }^{1}$, Robin Verjans ${ }^{1}$, Rick van Leeuwen ${ }^{1}$, Tim Peters ${ }^{1}$, Paolo Carai ${ }^{2}$, Eleni Liapi ${ }^{1}$, Wolfgang Poller ${ }^{3}$, Marc van Bilsen ${ }^{1,4}$, Blanche Schroen ${ }^{1}$

1 Department of Cardiology, CARIM School for Cardiovascular Diseases, Maastricht University, Universiteitssingel 50, 6200 MD Maastricht, the Netherlands.

2 Center for Heart Failure Research, Cardiovascular Research Institute Maastricht, The Netherlands; Molecular and Vascular Biology, Department of Cardiovascular Sciences, KU Leuven, Belgium

3 Department of Cardiology and Pneumology, Campus Benjamin Franklin, Charité - Universitätsmedizin Berlin, Berlin, Germany Berlin Center for Regenerative Therapies (BCRT), Charité - Universitätsmedizin Berlin, Berlin, Germany German Center for Cardiovascular Research (DZHK), Site Berlin, Germany

4 Department of Physiology, CARIM School for Cardiovascular Diseases, Maastricht University, Universiteitssingel 50, 6200 MD Maastricht, the Netherlands

In preparation 


\section{Chapter 6}

\section{MicroRNA-200c-3p induces cardiomyocyte hypertrophy and cardiac dysfunction, and is involved in titin signalling}

Steffie Hermans-Beijnsberger ${ }^{1}$, Robin Verjans ${ }^{1}$, Patrick Schönleitner ${ }^{2}$, Annika Kuhn ${ }^{1}$, Rick van Leeuwen ${ }^{1}$, Wouter Verhesen ${ }^{1}$, Paolo Carai ${ }^{3}$, Silvia Bonilla García', Jolanda van der Velden ${ }^{4}$, Gudrun Antoons ${ }^{2}$, Nazha Hamdani $^{5}$, Marc van Bilsen ${ }^{1,2}$, Blanche Schroen $^{1}$

1 Department of Cardiology, CARIM School for Cardiovascular Diseases, Maastricht University, Universiteitssingel 50, 6200 MD Maastricht, the Netherlands.

2 Department of Physiology, CARIM School for Cardiovascular Diseases, Maastricht University, Universiteitssingel 50, 6200 MD Maastricht, the Netherlands

3 Center for HeartFailure Research, Cardiovascular Research Institute Maastricht, The Netherlands; Molecular and Vascular Biology, Department of Cardiovascular Sciences, KU Leuven, Belgium

4 Amsterdam UMC, Department of Physiology, Vrije Universiteit Amsterdam, Amsterdam Cardiovascular Sciences, O2 building 11W53, De Boelelaan 1117, 1081HV, Amsterdam, The Netherlands.

5 Department of Systems Physiology, Ruhr University Bochum, Bochum, Germany.

In preparation 


\section{Chapter 7}

General discussion 



\section{Conclusion thesis}

In this thesis we investigated the role of candidate non-coding RNAs (ncRNAs) in the pathophysiology of heart failure (HF). HF can have different etiologies, including pressure overload leading to maladaptive cardiac hypertrophy, and viral infections leading to myocarditis ${ }^{1}$. Despite the major advancements in therapies for HF patients, quality of life after HF diagnosis is still poor ${ }^{2}$. Indeed, current therapies are only partly effective as evidenced by a mortality rate of $300,000 \mathrm{HF}$ patients each year ${ }^{3}$. With the molecular exploration of the pathophysiology underlying this disease, we will be able to understand better the biological reactions of the cardiac cells in response to the diverse stressors implicated in HF, like increased pressure and (neurohormonal) stress signaling leading to cardiomyocyte growth and remodeling, cardiac interstitial fibrosis, (micro)vascular dysfunction and inflammation. In this thesis we focus on the cardiomyocyte specifically, and contribute to the understanding of ncRNA mechanisms involved in the development of HF. In the current chapter, we will discuss briefly the main results of each chapter, and place the findings in the broader perspective of the state-of-the-art in cardiovascular research.

\section{LncRNAs in the cellular processes underlying HF}

Pathophysiological processes underlying the development of HF include cardiac hypertrophy, cardiac fibrosis, inflammation, vascular disease, and ageing ${ }^{4,5}$. NcRNAs have been proven to play significant roles in many cellular processes in the heart, and gaining knowledge on their functions will increase our understanding of HF pathophysiology. MicroRNAs (miRs) were the first ncRNA molecules that attracted scientific interest in the cardiac field $^{6,7}$, starting over 10 years ago. In the meantime, tremendous resources, time and effort have been put into moving miR-based therapies towards clinical practice, but it is too early to speak of successes and there are still some hurdles to overcome. More recently, long ncRNAs (IncRNAs) started to gain attention across biological fields. Although their nucleotide sequences are less conserved than those of miRs, their roles in cellular processes are widespread, as we summarized for cardiovascular disease (CVD) in Chapter $2^{8}$. So far, studies investigating the role of IncRNAs in CVD and ageing leading to HF are limited, and understanding their role in HF-associated processes is important to find new therapeutic candidates. However, experimental challenges to study biological roles for IncRNAs are substantial. Unlike miRs, IncRNAs act by various mechanisms and function in a broad range of processes, from DNA binding to affect gene expression, to diverse roles in the cytoplasm. LncRNAs often function in a highly spaciotemporal restricted manner, and therefore their manipulation by knockout or overexpression may be too artificial. Moreover, IncRNAs are often too long to fit into expression vectors to study the cellular consequences of their increased presence, and knockdown is at times difficult because of the temporary nature of their expression, inaccessible subcellular localization and/or complex tertiary structures. It is unknown but plausible that IncRNAs, like proteins, have functional domains, and the prediction of these domains based on structure is still in its infancy. Developing modifiers for these domains, like small molecules or aptamers, will shed light on their functions ${ }^{9}$. In addition, CRISPR/Cas technology makes it easy to investigate functionalities of (parts/domains) of IncRNAs in higher throughput ${ }^{10}$. Taken together, IncRNA research may need more time than miR research for the design of standardized experimental approaches, compared to antagomiRs and mimics for miRs. On the other hand, IncRNA 
research will profit from the methods already established for miR research, including the antagomiR-equals for IncRNAs, gapmeRs ${ }^{11}$, and from the major recent advancements in molecular biological and genetical tools in general, like CRISPR Cas and single cell RNA sequencing technologies ${ }^{12}$. Using the latter, IncRNA presence in different cellular stages can be analysed ${ }^{13}$.

Currently, IncRNAs are mostly studied for their use as biomarkers, especially in CVD. The same was true for miRs in their early days, with huge expectations for their biomarker potential. Although circulating miRs are stable, their reliable and fast detection represents a challenge that has not yet been fully overcome ${ }^{14}$. Time will tell if IncRNAs are more suitable as biomarkers, but initial reports show that their levels in the circulation are very low ${ }^{15}$.

\section{Roles for IncRNAs in the cellular processes underlying pressure overload-induced HF}

In Chapter $\mathbf{3}$ and $\mathbf{4}$ of this thesis we contribute to the current knowledge of IncRNAs in HF, in which we investigate Malat1 and Neat1 in cardiac hypertrophy and failure. These IncRNAs both are abundantly present in the nucleus of each mammalian cell, and are encoded from adjacent genomic regions. In Chapter 3, Malat1 was found to be dispensable during pressure-overload ${ }^{16}$. The Malat1 gene gives rise to many transcripts in human and mice ${ }^{17}$. As only the first exon was knocked-out in the mouse model that was used to study its cardiac roles, we cannot exclude that some transcripts were not depleted in our mouse model. Therefore, additional studies are required. In contrast, depletion of Neat1 was found to be protective against pressure overload-induced HF (Chapter 4). We demonstrate that mice lacking Neat1 respond differently to an increased afterload (induced by transverse aortic constriction): cardiac remodeling pathways and processes were attenuated, preventing cardiac remodeling and failure. The exact manner in which Neat1 exerts its function in the heart and contributes to HF remains elusive, and unraveling the underlying mechanism is crucial to understand the pathophysiology of cardiac hypertrophy and failure. Maybe in the future, therapeutic depletion of Neat1 transcripts in cardiomyocytes in humans will be effective to stop HF progression during e.g. chronic hypertension or aortic valve stenosis.

\section{NcRNAs as therapeutic targets for virus-induced HF}

Excessive inflammation of the heart, commonly referred to as myocarditis, can be the result of a viral infection ${ }^{18}$. Myocarditis is characterized by a broad range of pathological processes, which include immune cell activation, cardiomyocyte dysfunction and apoptosis, structural changes like fibrosis, and overall cardiac dysfunction. The diagnosis and treatment of viral myocarditis (VM) patients are the most challenging in cardiology. Depending on the etiology, treatment consists of antiviral or immune suppressive agents. Still, a substantial number of patients with VM shows viral persistence and/or develops dilated cardiomyopathy which can progress into HF ${ }^{19}$. Therefore, there is a need for new insights in the pathophysiology of VM and for alternative therapies. Although it is still early days, a few studies have proven in murine models of acute VM that miR inhibtors can serve as antiviral or anti-inflammatory agents ${ }^{20}$. Treatment with anti-miR-1 was shown to inhibit Coxsackie virus B3 (CVB3) replication in cardiomyocytes in CVB3-induced murine myocarditis ${ }^{21,22}$, 
possibly via Cx43 which has been associated with HIV-related CVD. Additionally, our lab demonstrated that anti-miR-155 could serve as anti-inflammatory therapy in VM ${ }^{23}$. In this study miR-155 can regulate PU.1, an inhibitor for antigen presentation by dendritic cells ${ }^{24}$, and anti-miR-155 treatment of CVB3-infected mice improved cardiac function with reduced mortality after 7 weeks of VM ${ }^{23}$. Additionally our lab identified $m i R-221 / 222$ as crucial regulators of both the antiviral and immune response in $\mathrm{VM}{ }^{25}$. These studies together provide evidence that miRs regulate processes crucial for the development of VM, and show that miR inhibition has therapeutic potential for both the inhibition of immune responses as well as the control of viral replication. However, how these studies will be transited towards clinical reality, and in which patients these therapies can be successful (due to diversity of other cardiotropic viruses and often more long-term cardiac issues), remains an open issue.

In this thesis, we addressed the potential of synthetic mascRNA (s-mascRNA) as a new therapeutic bioagent for viral myocarditis (Chapter 5). MascRNA is a small tRNA-like ncRNA molecule that we identified before for its ability to inhibit viral replication in cardiomyocytes. Here, we confirm the antiviral function of (s-)mascRNA both in vitro and in vivo. We show that s-mascRNA reduces CVB3 infectious particles secreted by cardiomyocytes, but has no effect on viral protein production in infected cardiomyocytes. In addition, s-mascRNA shifts the cell cycle distribution in cardiomyocytes. Both effects may be, at least in part, mediated by binding of s-mascRNA to Poly(C)-binding protein 2 (PCBP2), an endogenous factor important for both CVB3 replication and cell cycle progression ${ }^{26,27}$. S-mascRNA has a great potential of being developed into a therapy, as it has very potent antiviral effects and it is relatively easy to produce. We used a 'naked' oligo that was transfected into cardiomyocytes, which without any additional modifications, had significant impact on viral levels. However, further studies will need to investigate timing and dosing strategies.

\section{NcRNAs as novel therapeutic targets for diastolic dysfunction and HFpEF}

Diastolic dysfunction is one of the characteristics of clinical HF, particularly HF with preserved ejection fraction (HFpEF), and is characterised by cardiomyocyte hypertrophy and increased passive tension ${ }^{28,29}$. Cardiomyocyte hypertrophy is associated with increased cardiomyocyte volumes, re-expression of fetal genes and upregulation of protein synthesis

30. The biggest protein in cardiomyocytes is titin, which has been extensively studied for its role in regulating passive tension ${ }^{31}$. Changes in titin isoform expression, mutations in the genomic region that code for the titin gene, and protein-binding partners affecting the titin molecule, can all affect cardiomyocyte and cardiac stiffness, as well as cardiomyocyte hypertrophy although the latter is incompletely understood ${ }^{32}$. Protein-binding partners of cardiac titin, including muscle-specific LIM protein (MLP), FHL1 and 2, ERK2 and muscle specific RING finger protein (MURF), are part of a titin-associated signalosome that can regulate hypertrophic signalling, especially in the cardiac muscle ${ }^{32}$. Understanding the regulation and function of titin is key to find new possible therapies to counteract HFassociated stiffness and possibly hypertrophy of the myocardium.

To our knowledge, no evidence exists for ncRNAs regulating functions of titin. Only one miR has been associated with titin: $m i R-22$ knock-out mice have reduced cardiac titin levels upon 
pressure overload, as well as reduced levels of additional proteins associated with the cardiac $Z$ disk/titin cytoskeleton ${ }^{33}$. Whether this effect of miR-22 on cytoskeletal genes is direct or indirect, remains elusive.

Studying titin functions is challenging and requires specialised expertise in both the molecular biology of titin, with its many isoforms and phosphorylation sites and stressresponsive alternative splicing and phosphorylation, as well as in experimental tools to address this giant protein in the lab. Collaborations with dedicated "titin labs" are therefore crucial. By doing so, we here demonstrate that a ncRNA, miR-200c, can affect titin isoform levels and phosphorylation in the heart and in the hypertrophic cardiomyocyte (Chapter 6). In cardiomyocytes, overexpression of miR-200c caused an increase in cell size and upregulation of fetal genes. These effects may be mediated by the direct miR-200c target, FHL1, but this needs further investigation. Interestingly, miR-200c affected titin isoform expression in vitro and in vivo, and in vivo phosphorylation of the N2B isoform. Long-term overexpression of $m i R-200 c$ in the heart caused an increase in heart weight combined with impaired function. These findings can have major impact in the field of cardiology, since this suggests ncRNAs can modulate functions of the giant protein titin, although further studies are required to show that miR-200c effects on titin lead to differential titin stiffness and cardiomyocyte passive tension.

Metabolic diseases including diabetes, obesity and hypertension are important risk factors for diastolic dysfunction and $\mathrm{HFpEF}{ }^{34}$. HFpEF is currently a major clinical challenge, as standard HF treatment with a combination of medications including Angiotensin-converting enzyme inhibitors, beta blockers an diuretics, is ineffective in HFpEF patients ${ }^{35}$. In Chapter 6, we found increased expression of miR-200c in metabolic disease-induced murine HF models. Under normal conditions, cardiac miR-200c levels are low, but upon metabolic stress in mice and rats, cardiac miR-200c levels were induced 2- to 6-fold. If miR-200c levels also rise in the hearts of HFpEF patients, it would be therapeutically interesting to block miR-200c levels. As it is not present at baseline, it will only affect cells that upregulate miR-200c, once delivered to the heart. However, ncRNA-based therapies are still a major challenge and will be discussed hereafter.

\section{NcRNA-based therapy, reality or fantasy?}

This thesis, as well as other's scientific publications provide evidence that ncRNAs can be an interesting class of molecules for therapeutic targeting in CVD, as they are involved in a number of crucial processes in the development or progression of CVD. The challenges lie in the delivery of therapies to the right place and at the right time, and in the successful targeting of ncRNAs that either in- or decrease availability. Depleting ncRNA levels in vivo can be achieved by antisense oligonucleotides (ASOs) or small interfering RNAs (siRNAs). The most widely used ASOs are antagomiRs for miRs and GapmeRs for IncRNAs. AntagomiRs are single-stranded RNA molecules 21-23 nucleotides in length, complementary to the mature target miR. Intravenous administration is able to inhibit miR levels in many organs, including the heart ${ }^{36}$. GapmeRs are single stranded antisense oligonucleotides that bind to specific target RNA of any length, also by complementarity. The double-stranded DNA:RNA heteroduplexes are cleaved by intracellular proteins and decrease target RNA levels ${ }^{37}$. The huge disadvantage of these current methods is the 
biodistribution; the therapy will be delivered to multiple organs if injected intravenously. A solution would be to inject directly into the target organ, but a dynamic and blood-expelling organ like the heart will not be able to contain such targeted delivery. Other solutions that are under investigation are microbubbles, nanoparticules and AAV-based strategies with heart-specific promotors ${ }^{38-40}$. Still, other solutions need to be found to better control the half-life of ncRNA-based therapies. Therefore, getting the RNA-based therapy at the right moment at the right place is still a major challenge that requires further optimization.

Overexpression or sponging of ncRNAs can be achieved by viral-associated gene transfer, for example adeno-associated virus (AAV). AAV9-vectors have tropism for the heart and have been proven to induce RNA expression in cardiomyocytes with minimal off-target effects, especially smaller IncRNAs (up to $5 \mathrm{~kb}$ ) ${ }^{41}$ and miRs ${ }^{42,43}$. In addition, mimics can be used to overexpress miRs. Like antagomiRs, mimics are RNA molecules that have the exact same nucleotide sequence as its endogenous miR, thereby mimicking the role of the miR of interest ${ }^{44}$. However, causation has to be taken when applying antagomiRs or mimics as they get cleared by the liver and kidney, causing supposedly off-target effects ${ }^{45}$. Additionally, relatively high doses are needed the get to a therapeutic efficient level in the heart ${ }^{46}$.

Overall, ncRNA-based therapy is still challenging, but will become available in the future. Several clinical trials have been initiated on ncRNA therapy, including a miR-122 inhibitor to treat hepatitis $C$, supporting a future role in the clinic ${ }^{42}$. 


\section{References}

1. Metra, M. \& Teerlink, J. R. Heart failure. Lancet 6736, (2017).

2. Hobbs, F. et al. Impact of heart failure and left ventricular systolic dysfunction on quality of life A crosssectional study comparing common chronic cardiac and medical disorders and a representative adult population. Eur Hear. J 23, 1867-1876 (2002).

3. Bui, Anh, L., Horwish, Tamara, B. \& Fonarow, Gregg, C. Epidemiology and risk profile of heart failure. Nat. Publ. Gr. 8, 1-25 (2012).

4. Strait, J. B. \& Lakatta, E. G. Aging-Associated Cardiovascular Changes and Their Relationship to Heart Failure. Heart Fail. Clin. 8, 143-164 (2012).

5. Azevedo, P. S., Polegato, B. F., Minicucci, M. F., Paiva, S. A. R. \& Zornoff, L. A. M. Cardiac Remodeling: Concepts, Clinical Impact, Pathophysiological Mechanisms and Pharmacologic Treatment. Arq. Bras. Cardiol. 62-69 (2016). doi:10.5935/abc.20160005

6. Barwari, T., Joshi, A. \& Mayr, M. MicroRNAs in Cardiovascular Disease. J. Am. Coll. Cardiol. 68, 25772584 (2016).

7. Verjans, R., van Bilsen, M. \& Schroen, B. MiRNA Deregulation in Cardiac Aging and Associated Disorders. International Review of Cell and Molecular Biology 334, (Elsevier Inc., 2017).

8. Hermans-Beijnsberger, S., Van Bilsen, M. \& Schroen, B. Long non-coding RNAs in the failing heart and vasculature. Non-Coding RNA Res. 3, 118-130 (2018).

9. Germer, K., Leonard, M. \& Zhang, X. RNA aptamers and their therapeutic and diagnostic applications. Int J Biochem Mol Biol 4, 27-40 (2013).

10. Li, P., Fu, X., Zhang, L. \& Li, S. CRISPR/Cas-based screening of a gene activation library in Saccharomyces cerevisiae identifies a crucial role of OLE1 in thermotolerance. Microb Biotechnol nov, (2018).

11. Grünweller, A. \& Hartmann, R. K. Locked Nucleic Acid Oligonucleotides: The Next Generation of Antisense Agents? BioDrugs 21, 235-243 (2007).

12. Hwang, B., Lee, J. H. \& Bang, D. Single-cell RNA sequencing technologies and bioinformatics pipelines. Exp. Mol. Med. 50, 96 (2018).

13. Kim, D. H. et al. Single-cell transcriptome analysis reveals dynamic changes in IncRNA expression during reprogramming. Cell Stem Cell 16, 88-101 (2015).

14. Rech, M., Barandiara, A., Empel, V. Van, Bilsen, M. Van \& Schroen, B. Pathophysiological understanding of HFpEF: microRNAs as part of the puzzle. Cardioavsc Res 114, 782-793 (2018).

15. Hermans-Beijnsberger, S., Van Bilsen, M. \& Schroen, B. Long non-coding RNAs in the failing heart and vasculature. Non-Coding RNA Res. 3, 118-130 (2018).

16. Peters, T. et al. Long non-coding RNA malat-1 is dispensable during pressure overload-induced cardiac remodeling and failure in mice. PLoS One 11, (2016).

17. Kent, W. J. et al. The Human Genome Browser at UCSC. Genome Res 12, 996-1006 (2002).

18. Sagar, S., Liu, P. P. \& Cooper, L. T. J. Myocarditis. Lancet 379, 738-747 (2012).

19. Kearney, M. T., Cotton, J. M., Richardson, P. J. \& Shah, A. M. Viral myocarditis and dilated cardiomyopathy : mechanisms, manifestations, and management. Postgr. Med J 77, 4-10 (2001). 
20. Omran, A., Elimam, D., Webster, K. A., Shehadeh, L. A. \& Yin, F. MicroRNAs: a new piece in the paediatric cardiovascular disease puzzle. Cardiol Young 23, 642-655 (2013).

21. Ye, X., Liu, Z., Hemida, M. G. \& Yang, D. Targeted Delivery of Mutant Tolerant Anti- Coxsackievirus Artificial MicroRNAs Using Folate Conjugated Bacteriophage Phi29 pRNA. PLoS One 6, (2011).

22. $\mathrm{Xu}, \mathrm{H}$. et al. MicroRNA- 1 represses Cx43 expression in viral myocarditis. Mol Cell Biochem 362, 141-148 (2012).

23. Corsten, M. F. et al. MicroRNA Profiling Identifies MicroRNA-155 as an Adverse Mediator of Cardiac Injury and Dysfunction During Acute Viral Myocarditis. Circ Res 111, 415-425 (2012).

24. Martinez-Nunez, R. T., Louafi, F., Friedmann, P. S. \& Sanchez-Elsner, T. MicroRNA-155 Modulates the Pathogen Binding Ability of Dendritic Cells ( DCs ) by Down-regulation of DC-specific Intercellular Adhesion Molecule-3 Grabbing non-integrin (DC-SIGN). J Biol Chem 284, 16334-16342 (2009).

25. Corsten, M. et al. The microRNA-221 / -222 cluster balances the antiviral and inflammatory response in viral myocarditis. Eur Hear. J 36, 2909-2919 (2015).

26. Chase, A. J., Daijogo, S. \& Semler, B. L. Inhibition of Poliovirus-Induced Cleavage of Cellular Protein PCBP2 Reduces the Levels of Viral RNA Replication. J Virol 88, 3192-3201 (2014).

27. Waggoner, S. A., Johannes, G. J. \& Liebhaber, S. A. Depletion of the poly(C)-binding proteins alphaCP1 and alphaCP2 from K562 cells leads to p53-independent induction of cyclin-dependent kinase inhibitor (CDKN1A) and G1 arrest. J Biol Chem 284, 9039-9049 (2009).

28. Rame, J. E. \& Dries, D. L. Heart Failure and Cardiac Hypertrophy. Curr Treat Options Cardiovasc Med 9, 289-301 (2007).

29. Zile, M. R. et al. Heart Failure Myocardial Stiffness in Patients With Heart Failure and a Preserved Ejection Fraction Contributions of Collagen and Titin. 1247-1259 (2015). doi:10.1161/CIRCULATIONAHA.114.013215

30. Heineke, J. \& Molkentin, J. D. Regulation of cardiac hypertrophy by intracellular signalling pathways. Nat. Rev. Mol. Cell Biol. 7, 589-600 (2006).

31. LeWinter, M. \& Grazier, H. Cardiac Titin: a multifunctional giant. Circulation 121, 2137-2145 (2010).

32. Linke, W. A. \& Krüger, M. The Giant Protein Titin as an Integrator of Myocyte Signaling Pathways. Physiology 25, 186-198 (2010).

33. Gurha, P. et al. Targeted Deletion of MicroRNA-22 Promotes Stress-Induced Cardiac Dilation and Contractile Dysfunction. Circulation 125, 2751-2761 (2012).

34. Lewinter, M. M. \& Meyer, M. Mechanisms of Diastolic Dysfunction in Heart Failure With If It's Not One Thing It's Another. Circ Hear. Fail 6, 1112-1115 (2013).

35. Berliner, D. \& Bauersachs, J. Current drug therapy in chronic heart failure - The new guidelines of the European Society of Cardiology (ESC). Korean Circ. J. 47, 543-554 (2017).

36. Mattes, J., Yang, M. \& Foster, P. S. Regulation of MicroRNA by Antagomirs A New Class of Pharmacological Antagonists for the Specific Regulation of Gene Function? Am J Respir Cell Mol Biol 36, 8-12 (2007).

37. Wahlestedt, C. et al. Potent and nontoxic antisense oligonucleotides containing locked nucleic acids. Proc. Natl. Acad. Sci. 97, 5633-5638 (2000).

38. Naso, M. F., Tomkowicz, B., Perry, W. 3rd \& Strohl, W. Adeno-Associated Virus (AAV) as a Vector for Gene Therapy. BioDrugs 31, 307-334 (2017). 
39. Wilczewska, A. Z., Niemirowicz, K., Markiewicz, K. H. \& Car, H. Nanoparticles as drug delivery systems. Pharmacol. Reports 64, 1020-1037 (2012).

40. Tsutsui, J. M., Xie, F. \& Porter, R. T. The use of microbubbles to target drug delivery. Cardiovasc Ultrasound 16, 23 (2004).

41. Viereck, J. et al. Long noncoding RNA Chast promotes cardiac remodeling. Sci. Transl. Med. 8, 326ra22$326 r a 22$ (2016).

42. Chamberlain, K., Riyad, J. M. \& Weber, T. Expressing Transgenes That Exceed the Packaging Capacity of Adeno-Associated Virus Capsids. Hum Gene Ther Methods 27, 1-12 (2016).

43. Pacak, C. A. et al. Recombinant adeno-associated virus serotype 9 leads to preferential cardiac transduction in vivo. Circ Res 99, 3-9 (2006).

44. Wang, Z. The Guideline of the Design and Validation of MiRNA Mimics. (2010).

45. Obad, S. et al. Silencing of microRNA families by seed-targeting tiny LNAs. Nat Genet 43, 371-378 (2011).

46. Ameres, S. L. et al. Target RNA-directed trimming and tailing of small silencing RNAs. Science (80-. ). 328, 1534-1539 (2010). 


Summary 

In the studies described in this thesis I investigated the cause and development of heart failure. Heart failure is a disease in which the heart is unable to pump sufficient amount of blood to the rest of the body. This causes symptoms such as shortness of breath, fatigue, and swelling (edema). Heart failure can be caused by a heart infarct, a viral infection in the heart muscle, chronic hypertension, or by a combination of obesity, diabetes and high blood pressure. The increased workload and stress experienced by the heart muscle causes compensation, in which the heart muscle growths (hypertrophy) to meet the body's needs. Unfortunately, on the long-term this will lead to more damage to the heart tissue and a deteriorated heart function. Heart failure is difficult to diagnose; there are several examinations necessary such as blood tests, physical exam, and for example an ultrasound of the heart. After diagnoses, a treatment plan will be prepared, with the goal to alter for example the cause of heart failure. These treatments can include: treatment of high blood pressure, a surgery to place a stent or a new heart valve, or treatment of arrhythmia caused by the damage heart muscle. Despite the effective treatment options, there are still many patients that suffer from heart failure. In the Netherlands 7,700 people die every year due to this devastating disease.

In the chapters of this thesis I looked for new opportunities to better understand heart failure, and tried to find new treatment options. I investigated new molecules at a cellular- and organ-level that can influence the development of heart failure. The specific molecules I studied are called non-coding RNA molecules. In this thesis I showed you that one of these molecules, Neat1, was essential for the development of hypertrophy while the heart muscle was under great pressure. We used a mouse model in which this molecule is deleted. In normal, control mice, an increased workload leads to growth of the heart muscle. However, the mice which did not have the Neat1 molecule anymore, turned out to not develop a bigger heart and moreover they did not developed heart failure (Chapter 4). Additionally we show that another non-coding RNA molecule, mascRNA, the multiplication and distribution of a viral infection in the cardiac muscle cells can counteract. We used animal cardiac muscle cells that were infected with a virus. After the addition of the mascRNA molecule we saw that the viral infection was inhibited (Chapter 5). In the last research chapter of this thesis I described a project in which we determined the effect of adding a non-coding RNA molecule, miR-200c, to cardiac muscle (cells), in cell culture as well as in mouse models. We saw that the miR-200c molecule caused the cardiac muscle cell to grow and possibly also caused heart failure. Future investigation has to find out how this miR-200c molecule exactly functions and if we perhaps can inhibit the expression to maintain a normal heart function or to prevent dysfunction (Chapter 6).

In conclusion, non-coding RNA molecules play an important role in the development of heart failure and improve the knowledge about cellular mechanisms involved that can cause this disease. 

Samenvatting 

In de studies die beschreven staan in dit proefschrift onderzocht ik de oorzaak en ontwikkeling van hartfalen. Onder hartfalen verstaan we het onvermogen van het hart om voldoende bloed naar de rest van het lichaam te pompen. Hierdoor ontstaan er symptomen zoals kortademigheid, vermoeidheid en het vasthouden van vocht. Hartfalen kan ontstaan door een hartinfarct, virale infectie van de hartspier, langdurige hoge bloeddruk, of door een combinatie van overgewicht, suikerziekte en hoge bloeddruk. Door de verhoogde werkdruk en stress die het hart ervaart, treedt er compensatie op, waardoor de hartspier groeit (hypertrofie) om aan de behoefte van het lichaam te voldoen. Helaas leidt dit op lange termijn tot meer schade aan het hartweefsel en tot een verslechterde hartfunctie. Hartfalen is moeilijk te diagnosticeren; er zijn meerdere onderzoeken voor nodig zoals bloedonderzoek, lichamelijk onderzoek, en b.v. een echo maken van het hart. $\mathrm{Na}$ de diagnose wordt er een behandelplan opgesteld, met als doel invloed uit te oefenen op b.v. de oorzaak van hartfalen. Denk aan de behandeling van hoge bloeddruk, een operatie ondergaan waarbij b.v. een stent of een nieuwe hartklep wordt geplaatst, of het behandelen van hartritmestoornissen die kunnen ontstaan door de schade aan het hart. Ondanks de effectiviteit van deze behandelingen, zijn er nog steeds veel patiënten die lijden aan hartfalen. In Nederland overlijden jaarlijks 7,700 mensen aan deze ziekte.

In de hoofdstukken van dit proefschrift zocht ik naar aangrijpingspunten om hartfalen beter te kunnen begrijpen, en om nieuwe behandelmethoden te kunnen ontwikkelen. Hiervoor zocht ik op cellulair- en orgaan-niveau naar moleculen die van invloed kunnen zijn op de ontwikkeling van hartfalen. De specifieke moleculen die ik onderzocht noemen we nietcoderende RNA moleculen. In dit proefschrift laat ik zien dat een van deze moleculen, Neat1, een essentiële bijdrage levert aan het ontstaan van een vergroot hart tijdens een verhoogde belasting van het hart. We gebruikten een muismodel waarin dit molecuul niet meer voorkomt. Bij gewone, controle muizen leidt een verhoogde werklast van het hart tot een vergrote hartspier. Echter, de muizen die het Neat1 molecuul niet hebben, bleken geen vergroot hart en daarbij ook geen hartfalen te ontwikkelen (Chapter 4). Verder laten we zien dat een ander niet-coderend RNA molecuul, mascRNA, het vermeerderen en verspreiden van een virale infectie in hartspiercellen kan tegen gaan. We gebruikten hiervoor dierlijke hartspiercellen die geïnfecteerd werden met een virus. Na toevoeging van het mascRNA molecuul zagen we dat de virale infectie werd geremd (Chapter 5). In het laatste onderzoekshoofdstuk beschrijf ik het project waarin we bekeken wat het effect was van het toevoegen van een niet-coderend RNA molecuul, miR-200c, aan de hartspier(cellen), zowel in celkweek als in muismodellen. We zagen hier dat het miR-200c molecuul een vergrote hartspiercel kan veroorzaken en daarbij mogelijk ook hartfalen. Verder onderzoek moet uitwijzen, hoe dit precies in z'n werk gaat en of we eventueel dit molecuul kunnen remmen om een goede hartfunctie te behouden of dysfunctie te voorkomen (Chapter 6).

In conclusie, niet-coderende RNA moleculen spelen een belangrijke rol in de ontwikkeling van hartfalen en geven een nieuwe kijk op de cellulaire mechanismen die deze ziekte kunnen veroorzaken. 

Valorization 



\section{Socio-economic relevance}

Heart failure (HF) is a global health problem, it affects 26 million people worldwide ${ }^{1}$. In total $27.7 \%$ of deaths were attributed to HF in 2015 , which has increased over the years ${ }^{2}$. The diagnosis HF impacts the lives of patients and their relatives and friends. The quality of life of these patients is poor and the disease controls their daily activities ${ }^{3}$. Next to the physical boundaries they experience, the mental impact is also significant. At the moment, these patients are treated with drugs that only affect the symptoms, but will not cure the disease, such as angiotensin-converting enzyme inhibitors, beta blockers and diuretics 4 . Unfortunately, the fatality rate after hospitalization for HF is $42 \%$ in 5 years, which is still extremely high ${ }^{2}$. There are no other treatment options and therefore we have to invest money and time to find new therapies that can help these patients. Such new therapies may improve the quality of life, increase the life expectancy, and even prevent the development of HF.

Next to the impact on the patient's life, there is a huge economic burden that co-exists with $\mathrm{HF}$. Due to an ageing population, the prevalence of HF will increase which will result in a tremendous cost for society ${ }^{1,2}$. Especially the costs for treating HF comorbidities and HF symptoms in youths are significant ${ }^{2,5}$. Therefore finding new therapies that will save lives, decrease care costs and help patients to improve quality of life will lower this burden.

To find new therapies, we have to understand the pathophysiology of heart failure and all its different symptoms and co-morbidities. In this thesis we aim to add small pieces to a big puzzle that represents cellular mechanisms involved in the development of HF. We investigated relatively new molecules, called non-coding RNAs (ncRNAs), that turn out to be important mediators of pathophysiology in different disease models of HF, and are also associated with human HF. Here we share these new findings and to show their potential, thereby we aim to open doors to find new ways to diagnose and treat HF.

\section{Target groups}

In this thesis we provide new insights in the mechanisms underlying HF, by investigating molecular mechanisms involved in several etiologies that can cause HF. Understanding which molecules are involved in cellular signaling pathways that underlie the heart's responses to pressure overload, viral myocarditis and metabolic-induced HF, improves basic knowledge of cell biology. The scientific community will benefit by improving awareness and by increased motivation to study these ncRNA molecules. In addition, the new functional roles of ncRNAs that we identified in this thesis might be applicable to cross scientific borders to other disciplines, such as cancer biology, neuroscience and liver metabolism. This has already been proven for miR-200c, Neat1 and Malat1 that all play a role in cancer biology ${ }^{6-8}$.

Besides the scientific community, pharmaceutical companies are an important target group for this thesis; they invest in developing new drugs, including ncRNA-based therapies. Several attempts have been made to be able to deliver ncRNA therapy at the right place in the human body, such as antagomiRs. GapmeRs, siRNAs, and AAV9-based viruses 9 . Recently, the first clinical trial has been launched using siRNAs against a specific long ncRNA in patients with thymoma and autoimmune disease (NCT02948855; Clinical trial 
database from US National Library of Medicine). In addition, we provide new insights in the role of ncRNAs that potentially can be used for future drug development.

In general, public institutes such as the NWO (Nederlandse Organisatie voor Wetenschappelijk Onderzoek) and the Netherlands Heart Foundation can profit from the data observed in this thesis. Based on the research results we share, one can actively discuss what the focus of cardiac research should be, and where investments need to be made.

\section{Activities, products and innovations}

This thesis presents basic research results that improve the knowledge of basic cell cardiology, as well as, deeper understanding of the pathophysiology of HF. Translating these results to clinical practice is the main goal, however still distant. This thesis is only a tip of the iceberg, many more efforts have to be made to explore this disease and to get a better understanding of the molecular and cellular processes involved in the development of HF. This thesis provides a piece of the big puzzle, and thereby may stimulate other researchers and other research areas to investigate ncRNAs. Moreover, we used several techniques to manipulate ncRNA levels in vitro and in vivo, using AAV9-based vectors, genetic knock-out models and synthetic oligos. These techniques need further development to assure limited side effects before they can be introduced into the clinic, but have great potential.

Cutting edge and innovative research is necessary to evolve and find new therapies. In this thesis we are the first to show that a small microRNA (miR-200c) is able to change the composition and activity status of a big protein such as titin (Chapter 6). In addition, we present long non-coding RNA Neat1 as a new player in the development of cardiac disease. Genetically depleted Neat 1 mice are protected from cardiac hypertrophic remodeling and failure (Chapter 4). Finally, a synthetic oligo named s-mascRNA, shows the potential to inhibit viral replication in cardiac myocytes (Chapter 5). This proves the importance of ncRNA molecules for future drug development.

\section{Planning and realization}

To be able to translate the findings in this thesis to the clinic will be the main goal and challenge of the future. Upcoming studies have to prove the possibility and applicability of using oligo-based tools to change the levels of ncRNAs and alter outcome. In addition, investigating the mode of actions of these molecules in the heart is crucial to be able to understand exactly what is happening in a pathophysiological condition such as HF. 


\section{References}

1. Savarese, G. \& Lund, L. H. Epidemiology Global Public Health Burden of Heart Failure. Card Fail Rev 3, 711 (2017).

2. Benjamin, E. et al. Heart Disease and Stroke Statistics - 2018 Update A Report From the American Heart Association. (2018). doi:10.1161/CIR.0000000000000558

3. Hobbs, F. et al. Impact of heart failure and left ventricular systolic dysfunction on quality of life A crosssectional study comparing common chronic cardiac and medical disorders and a representative adult population. Eur Hear. J 23, 1867-1876 (2002).

4. Berliner, D. \& Bauersachs, J. Current drug therapy in chronic heart failure - The new guidelines of the European Society of Cardiology (ESC). Korean Circ. J. 47, 543-554 (2017).

5. Nandi, D. \& Rossano, J. W. Epidemiology and cost of heart failure in children*. Cardiol. Young 25, 14601468 (2015).

6. Chakravarty, D. et al. The oestrogen receptor alpha-regulated IncRNA NEAT1 is a critical modulator of prostate cancer. Nat. Commun. 21, 5383 (2014).

7. Liu, Y. et al. MiR-200c regulates tumor growth and chemosensitivity to cisplatin in osteosarcoma by targeting AKT2. Sci. Rep. 7, 13598 (2017).

8. Ji, Q. et al. Long non-coding RNA MALAT1 promotes tumour growth and metastasis in colorectal cancer through binding to SFPQ and releasing oncogene PTBP2 from SFPQ / PTBP2 complex. Br. J. Cancer 111, 736-748 (2014).

9. Lucas, T. \& Dimmeler, S. RNA Therapeutics for Treatment of Cardiovascular Diseases Promises and Challenges. Circ Res 119, 794-797 (2016). 



\section{Dankwoord}



De afgelopen 4,5 jaar heb ik vele mooie en soms wat minder mooie momenten meegemaakt die alle deel uitmaken van mijn $\mathrm{PhD}$ en hebben geleid tot dit boekje. Deze momenten heb ik met vele mensen mogen delen en dat was voor mij de mooiste ervaring van dit hele project, daarvoor wil ik deze mensen hier graag bedanken.

Allereerst Blanche, jij hebt mij als PhD student aangenomen en hebt met mij menig meetings (minimeetings, group meetings, labmeetings, translational meetings, journal clubs) gehad en discussies gevoerd, al dan niet van wetenschappelijke aard. Je altijd vriendelijke en open instelling zorgde ervoor dat ik me thuis voelde op de afdeling en in ons cardiolab. Marc, jij bent na het eerste jaar mijn co-promoter geworden en hebt tijdens onze meetings veel wetenschappelijke input gegeven. Heel erg bedankt voor jullie support.

Daarnaast wil ik de leescommissieleden bedanken voor uw tijd en goedkeuring van mijn proefschrift, Prof. Leon Schurgers, Prof. Llewelyn Roderick, Prof. Rudolf de Boer en Dr. Vanessa van Empel.

Al het werk wat in dit proefschrift staat was nooit tot stand gekomen zonder mijn lab collega's (peeps). Wouter, vanaf het begin klikte het tussen ons en hebben wij (vanaf dag 1?) bij elkaar op kantoor gezeten, waren we marker buddies, en hebben tot in de puntjes uitgezocht wat de definitie is van oude kaas. Zonder jou had ik het nooit volgehouden. Bedankt voor de discussies, zanik, en vele klaag- en lachmomentjes. Rick, samen met Wouter ben je de vaste kern van ons lab. Stipt om 11:30 lunchen, tudududuuu let's go. Ondanks het vroege tijdstip hebben we ontzettend veel besproken tijdens onze lunchpauzes, en ging het meestal over eten, wijn of 24 kitchen. Bedankt voor al je steun en je open deur waar ik menig maal doorheen liep om te vragen of je iets wilde bestellen, om samen een in vitro experiment op te zetten, of naar een WB-tje te kijken.

Monika, we appen tegenwoordig in het Nederlands zodat jij kunt oefenen met onze taal, maar ik zal hier toch over gaan op het Engels. Dear Monika, you've became my best friend in the lab, the one I could always talk to, laugh with, have coffee breaks with, and complain with (a lot!) about work, life, whatever, and now you are standing next to me as my paranimf. Thank you for always having my back, and making the difficult moments at work a little easier. We keep in touch, as we already do, and we will have many more remembering moments. Robin, de eerste keer dat ik je ontmoette in real-life was toen je terug kwam uit Dresden, na 2 jaar weg geweest te zijn. Jij was en bent de ervaren collega waaraan je alles kunt vragen. Je hebt een enorme drive, niet alleen op wetenschappelijk gebied maar ook in je privé leven (even een marathon rennen, eredivisie handbal spelen, op en neer naar Italië vliegen, oh ja en daarnaast nog een $\mathrm{PhD}$ afronden). Heel veel succes in de toekomst, ik weet zeker dat 't je goed gaat. PIOONNNN!!! Robin and Monika, we had a great time together in Les Diablerets, including skiing, dancing, beer, shots, strange elevator rides, hangovers and a lots of fun, moments to never forget!

Annika, Lena, and Emma, my lab peeps, thanks for the support during these years and the scientific discussions. Annika, na je stage bleef je bij ons in het lab werken en begon je jouw PhD project. Je werd mijn kamergenootje en samen met Wouter hebben we de vrijdagmiddagen (als we het weer eens beu waren) zeer nuttig besteed en daarbij enorm gelachen (hoe zeg je dit in het duits? Hoe zeg je dit in het nederlands? En onze koffiebreaks die onmisbaar waren). Bedankt voor al je hulp en succes met je PhD! 
Ook wil ik de andere collega's van ons lab bedanken. Paolo, llona, Quentin, Kasper, thank you for all the practical help in- and outside of the lab, and good luck in your own career! Vincenza, Julie, Alexandra, Yannick, Anna, Sophie, Wouter D, Marieke, Georg and Tim, you have been out of the lab for a while now, but during my PhD you were always available for a chat or a discussion, thanks! Onze dokters onder leiding van Stephane: Mark, Jort, Job, Ward, Anne, Arantxa, en Michiel, bedankt voor de (on)zinnige discussies! Michiel, het is heerlijk om mit dig aaf en toe eins euver wat anges dan wirk te kalle en det dan aug nog in het Wieërts. Hiel vul succes mit dien PhD project en g weit zeker det we oas nog goan zeen.

I would like to thank also my colleagues from the "big cardio lab": Leon, Paul, Paula, Jordi, Roel, Sandrine, Servé, Cristina A, Cristina M, Rio, Burcu, Ellen, Mora, Martina, Lara, Marida, Federica, Indira, Nicolò, Zenab, and Andrea. Thank you all for the practical help in the lab, all the Italian jokes I probably didn't understand, and making PhD life much more doable. Andrea, we started together at this adventure, and we spent many hours together in the lab, I missed your happiness, enthusiasm and even the annoying Italian songs when you left. I hope you are doing well and good luck in the future.

All the labwork in this thesis would not have been possible without the work of my students: Ed, Cindya and Silvia. Thank you all for putting your effort and time in my project, and I hope you found your own way in or outside science. Good luck to you all!

Bedankt alle leden van de MF voor support tijdens de in vivo studies, DEC issues, en voor praktische hulp: Jacques, Helma, Agnieszka, Peter en Nicole. Nicole, bedankt voor alle uren die je met mij hebt doorgebracht om de in vivo studies tot een goed einde te brengen.

Aan alle CPV medewerkes, waaronder Clarice, Rik, Paulien, Richard en Saskia, waarmee ik het meeste contact heb gehad. Bedankt voor alle medewerking en voor altijd tijd vrij te maken zodat mijn onderzoek zo spoedig mogelijk kon verlopen.

Barbara, Lilian en Ingrid, bedankt voor alle rompslomp rondom de PhD en jullie open deur voor alle vragen. Barbara, bedanktj veur oaze babbel momentjes die ich zeker nudig haaj, heerlijk det plat kalle. Vul succes met 't $2^{\mathrm{e}}$ kleintje op komst en tot gauw.

Lauren, your loud and happy voice is something I can hear from miles away! Thank you for being always a happy, cheerful person, and being a member of the cool kids coffee club. See you around! Patrick, thanks for spending hours and hours in this little dark lab at physiology and putting so much effort into my research, good luck to you!

De Roze Olifantjes (\#FFCOCB), mijn lieve vrienden, we hebben elkaar leren kennen tijdens onze studie Biomedische Wetenschappen / Geneeskunde. Ook al weet ik niet meer hoe we allemaal bij elkaar terecht zijn gekomen, het is duidelijk dat onze vriendschap geen grenzen kent (Amerika, Denemarken, Australië, Rusland, ...). Na meer dan 10 jaar geleden begonnen te zijn met onze studie in Nijmegen, zijn we nog steeds een ontzettend hechte groep. In onze studententijd hebben we zó veel momenten gedeeld: altijd vanaf 16:00 uur in de Aesculaaf voor een biertje, soms tot in de Fuik (niet altijd een goed idee) of de Harmonie, alle weekendjes weg (ondertussen meer dan 15?!), zomervakanties, of gewoon koffiepauzes, het is te veel om op te noemen. En nu na onze studie zorgen we ervoor dat 
we elkaar nog steeds blijven zien, met jaarlijks een weekendje weg, de Nijmeegse Vierdaagse feesten en ons kerstdiner. Lieve jongens, Tim, Stephan, Dave, Lars, Coen, Ruud, Erik en Roy, bedankt voor deze mooie tijd en de tijd die nog komen zal! Onze chickies, Rosan, Pleun, Sarah, Rosalie, Carin, Charlotte, en Michelle, ik kan echt álles met jullie bespreken en we deelden met elkaar vele mooie en verdrietige momenten. Bedankt voor al jullie steun de afgelopen jaren en hopelijk mogen er nog vele volgen! Roze Olifantjes (en daar hoort ook alle aanhang bij!), onze vriendengroep is hechter dan wij soms beseffen, en wat hebben wij al veel meegemaakt met elkaar. Ik hoop dat we elkaar kunnen blijven steunen, mooie momenten met elkaar blijven delen, nog ontzettend veel zullen lachen, en vooral elkaar blijven zien zodat dit nooit meer verloren gaat, thanks allemaal!

Lieve Charlotte, wij zijn elkaar (bijna dagelijks!) blijven zien na onze studie in Nijmegen toen we beide besloten een $\mathrm{PhD}$ project te beginnen in Maastricht. Onze talloze koffiebreaks waarin daadwerkelijk álles besproken werd zal ik missen. Daarnaast hebben we nog vele mooie persoonlijke momenten mogen delen waarbij ik jouw getuige mocht zijn tijdens je bruiloft, we jullie weer eens op kwamen zoeken in Oostenrijk, we vlak na elkaar zwanger werden en we al ons beklaag bij elkaar konden doen en nu sta je naast mij als mijn paranimf. Ontzettend bedankt voor de afgelopen jaren, en dat er nog vele mogen volgen.

Dit proefschrift was nooit afgeweest als ik niet steun had gehad van mijn familie en vrienden. Mien volleybalteamies: Lieke, Chrissy, Kim, Judith, Anne, Merel, Daphne en Hèlen, bedanktj veur noets te klage als $g$ weer ins te laat waas oppe training waas, ich de training op het liste moment aafzagt omdat ich druk waas op het wirk, of als mien hoofd weer eins euverleep. Same mit jullie volleyballe waas nudig om mien hoofd leeg te maken en tot dit resultaat te komen. Jill \& Jeffrey, Roy, bedanktj det we same sjoene wintersport vakanties beleafdje, mit vaak iets te vul beer en iets te pittige kebab en groëete pizza's. Stijn, bedanktj veur altied interesse te hebben in mien wirk en om gewoen lekker mit te zeivere. Auke, bedankt voor het ontwerpen van deze unieke kaft! Het is ontzettend mooi geworden.

Mien biste vriendin, Moniek, Mo, wea zeen vrinj als sinds de ierste daag det we elkaar zoge op de middelbare sjool zoe ver g mig kan herinnere. Wea hebbe oaze jeugd same beleafdj, mit opstap goan, mixdrankjes, madeira, zwarte kots, sloapfiestjes (altied!), en enge manne, mer we hebbe $t$ allemoal euverleaftj. $G$ bin ontzettend blie des dig nog steeds miein biste vriendin bist en $\mathrm{g}$ altied bie dig terecht kan (aug al zeen we elkaar soms te weinig). Bedanktj veur alles!

Mijn schoonfamilie: Ad, Nicole, Désirée en Ramon, bedankt dat jullie altijd voor mij klaarstaan en dat ik Evan altijd langs kon brengen als ik weer eens weg moest voor werk.

Pap, hoe zal g beginne, dig bist degene die mig altied en euveral in steuntj. Dig hebs noets gezagtj det $\mathrm{g}$ iets neet kan of det $\mathrm{g}$ iets need mogt of most doon. Mede door dig staon $\mathrm{g}$ hie en heb g straks deze PhD aafgerondj. Robbert, broeder, wea hebbe neet vul weurd nudig om elkaar te begriepen. $\mathrm{G}$ weit det $\mathrm{g}$ altied bie dig terecht kan en angersom, en doa geit $\mathrm{t}$ om. G wins dig een sjoen toekomst, samen mit Simone (en Stormpie!). Pap en Robbert, aug al hebbe we t neet altied gemikkelik gehadj, we zeen er altied veur elkaar en det is wat tiltj. Zoe als we altied zigge, alles keumtj good, wea fixe det. 
Maikel, miene allerliefste, wea zeen al mier dan 12 joar same en hebbe een ontzettendj sterke bandj. Wea hebbe hiel vul lol en plezeer, wea kinne alles bespreake, en g weit zeker det wea veur elkaar gemaaktj zeen. Zonger dig haaj g hiej noets gestange, dig hebs altied geloestertj, mig gerusj gestiltj, mig getroosj en mig gemotiveertj om door te goan, bedanktj hie veur. Doa bie hebbe wea het geluk det we oaze liefde hebbe moge veere aafgelaupe joar mit de komst van oaze zoon Evan, wat is hea onzettend lief, vrolijk en veural gemikkelik. Ederein zeet waal, det kan neet anges mit zoe'n oajers, mer we hebbe het toch mer good veur mekaar, g hoaj van dig lief. Lieve Evan, aug al bisse nog zoe joonk en herinnerse dig deze daag later neet mier, $g$ wil dig eave good bedanke. Dien komst heet het liste joar van mien PhD mikkelijker gemaaktj. Als $\mathrm{g}$ thoes kwoom en dig lachdjes noa mig, waas $\mathrm{g}$ alle stress geliek vergeate. Dan wist $\mathrm{g}$ geliek weer wat belangriek is en wat mig gelukkig maaktj.

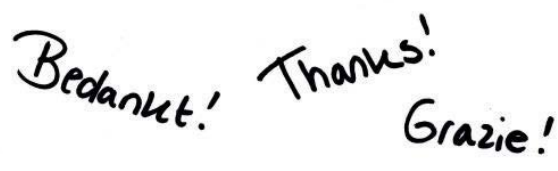

Steffie 


About the author 

Steffie Hermans-Beijnsberger was born in 1990 in Weert, the Netherlands. After high school, she studied Biomedical Sciences at the Radboud University in Nijmegen from 2008-2012. During this Bachelor she gained practical experience at the department of Biomaterials at the Radboud University where she performed her 4-month internship under the supervision of Dr. Wanxun Yang and Dr. Sanne Both. Here she studied the ability of cartilage formation into bone and how to stimulate this transition. After obtaining her Bachelor of Science degree, she continued at the Radboud University to do a Master Biomedical Sciences with a specific interest in pathobiology, in which she received her diploma in 2014. During this Master she performed a 6-month internship at the company Synthon, in Nijmegen. During this period she learned additional laboratory techniques including liquid immune-detection using the Octet platform. In addition she learned how to work with EMA/FDA guidelines, all under the supervision of Ellen Mattaar and Dr. David Egging. For the second Master internship she moved abroad to join the group of Prof. Heather Mefford under the supervision of Dr. Gemma Carvill at the University of Washington, Seattle, USA. For 8 months she learned how to perform several DNA laboratory techniques including DNA sequencing to identify genetic mutations that can cause an epileptic disease in children, called polymicrogyria. From this work she joined the Human Genetic Conference at Boston in October 2013 were she presented her research results.

Her interest in the human genome and the drive to focus on cellular mechanisms that cause disease brought her to join the experimental cardiology lab under supervision of Prof. Dr. Blanche Schroen and Dr. Marc van Bilsen. Here she started her PhD project focusing on the role of non-coding RNA molecules in cardiac disease. She presented her work at several conferences: the Winter Meeting on Translational Heart Failure Research by the Heart Failure Association and the Working Group on Myocardial Function of the European Society of Cardiology in January 2017 and 2018, les Diablerets, Switzerland; the Dutch-German Joint Meeting of the Molecular Cardiology Working Groups in March 2016, Leiden, the Netherlands; and the Keystone Symposia on Noncoding RNAs and Protein-RNA Interactions in February 2017, Banff, Canada. In addition she followed many trainings and courses to improve cardiac research knowledge, personal development, writing and communications skills. 

